\title{
Addition of Chiral and Achiral Allyltrichlorostannanes to Chiral $\alpha$-Alkoxy Aldehydes
}

\author{
Luiz C. Dias*, Tatiana Augusto, Carla C. Perez and Leonardo J. Steil \\ Chemistry Institute, State University of Campinas, UNICAMP, P.O. Box 6154, 13083-970 Campinas-SP, Brazil
}

\begin{abstract}
Aliltricloroestananas quirais e aquirais reagem com $\alpha$-alcóxi aldeídos quirais para fornecer alcoóis homoalílicos com moderados a bons níveis de diastereosseletividade 1,4-syn.

Achiral and chiral allyltrichlorostannanes reacted with chiral $\alpha$-alkoxy aldehydes to give the corresponding homoallylic alcohols with moderate to good levels of 1,4-syn-diastereoselection.
\end{abstract}

Keywords: allyltrichlorostannanes, allylsilanes, homoallylic alcohols

\section{Introduction}

Allylsilanes and allylstannanes are among the most important groups of organometallic-type reagents available for the control of acyclic stereochemistry and their reaction with aldehydes in the presence of Lewis acids is an important procedure for the preparation of homoallylic alcohols. ${ }^{1,2}$ The addition of allylstannanes bearing a stereogenic center to chiral aldehydes is particularly interesting in organic synthesis. We recently communicated that in situ prepared chiral allyltrichlorostannanes react with chiral aldehydes to give 1,4-syn homoallylic alcohols with high levels of diastereoselectivity. ${ }^{3-11}$

We wish to describe here a stereocontrolled reaction between achiral and chiral allyltrichlorostannanes with chiral lactate-derived aldehydes to give fragments which can be found in a large variety of naturally-occurring products with promising biological activities. ${ }^{12}$ This study details our efforts to understand the double stereodifferentiating stereocontrol elements involved in chiral allyltrichlorostannane additions to chiral aldehydes. ${ }^{13}$

\section{Results and Discussion}

Achiral and chiral allylsilanes 1-4 were prepared from the corresponding easily available methyl esters, as described in previous papers from this laboratory (Scheme 1). ${ }^{3-11,14}$ According to previously established experimental procedures, the allylsilanes were mixed with $\mathrm{SnCl}_{4}(1.0$ equiv. in $\mathrm{CH}_{2} \mathrm{Cl}_{2}$ ) before the addition of a solution of the aldehyde in order to promote the $\mathrm{SiMe}_{3} / \mathrm{SnCl}_{3}$ exchange

*e-mail: ldias@iqm.unicamp.br leading to the corresponding allyltrichlorostannanes $\mathbf{5 - 8}$ (Scheme 1). ${ }^{5}$

To the best of our knowledge, the first spectroscopic information available on exchange reactions involving allylsilanes and $\mathrm{SnCl}_{4}$ was reported by Denmark and co-workers in $1988 .{ }^{13}$ In 1999, we described the first direct evidence for interaction between $\mathrm{SnCl}_{4}$ and chiral allylic silane 3 bearing an ether functionality that generated a new species by means of NMR spectroscopy. ${ }^{5}$ In a continuation of these initial studies we have done a spectroscopic study $\left({ }^{1} \mathrm{H}\right.$ and $\left.{ }^{119} \mathrm{Sn} \mathrm{NMR}\right)$ of the reactions of allylsilanes $\mathbf{1 - 4}\left(0.15 \mathrm{molL}^{-1}\right.$ solution in $\mathrm{CDCl}_{3}$ ) with $\mathrm{SnCl}_{4}$ leading to the corresponding allyltrichlorostannanes 5-8, respectively (Scheme 1).

For allyltrimethylsilane 1 the $\mathrm{SiMe}_{3} / \mathrm{SnCl}_{3}$ exchange producing allyltrichlorostannane $\mathbf{5}$ and $\mathrm{Me}_{3} \mathrm{SiCl}$ is complete after $2 \mathrm{~h}$ at room temperature (Scheme 1). ${ }^{5}$ For allylsilane 2 the $\mathrm{SiMe}_{3} / \mathrm{SnCl}_{3}$ exchange to give $\mathbf{6}$ and $\mathrm{Me}_{3} \mathrm{SiCl}$ is faster, as expected for a 1,1-disubstituted electron-rich olefin, being complete after 10 minutes at room temperature. ${ }^{14}$ Upon addition of $\mathrm{SnCl}_{4}$ to a solution of allylsilanes $(R)-\mathbf{3}$ and $(S)-4$ in $\mathrm{CDCl}_{3}$, at $-60^{\circ} \mathrm{C}$, slightly yellow homogeneous solutions were obtained. The resulting NMR spectrum at $-60{ }^{\circ} \mathrm{C}$ showed formation of $\mathrm{Me}_{3} \mathrm{SiCl}$ and complete consumption of both allylsilanes within less than 1 minute to give allyltrichlorostannanes $(R)-\mathbf{7}$ and $(S)-\mathbf{8}$, respectively. It appears that the oxygen functionality is responsible for the rapid $\mathrm{SiMe}_{3} / \mathrm{SnCl}_{3}$ exchange reaction observed even at low temperatures for these particular allylsilanes and $\mathrm{SnCl}_{4}$. The $\mathrm{SiMe}_{3} / \mathrm{SnCl}_{3}$ exchange is probably facilitated by coordination of tin to this oxygen followed by cleavage of the carbon-silicon bond by a free chloride ion.

Analysis of the corresponding ${ }^{1} \mathrm{H}$ NMR spectrum showed a deshielding for hydrogens $\mathrm{H}_{1}$ to $\mathrm{H}_{4}$ in allylstannane 


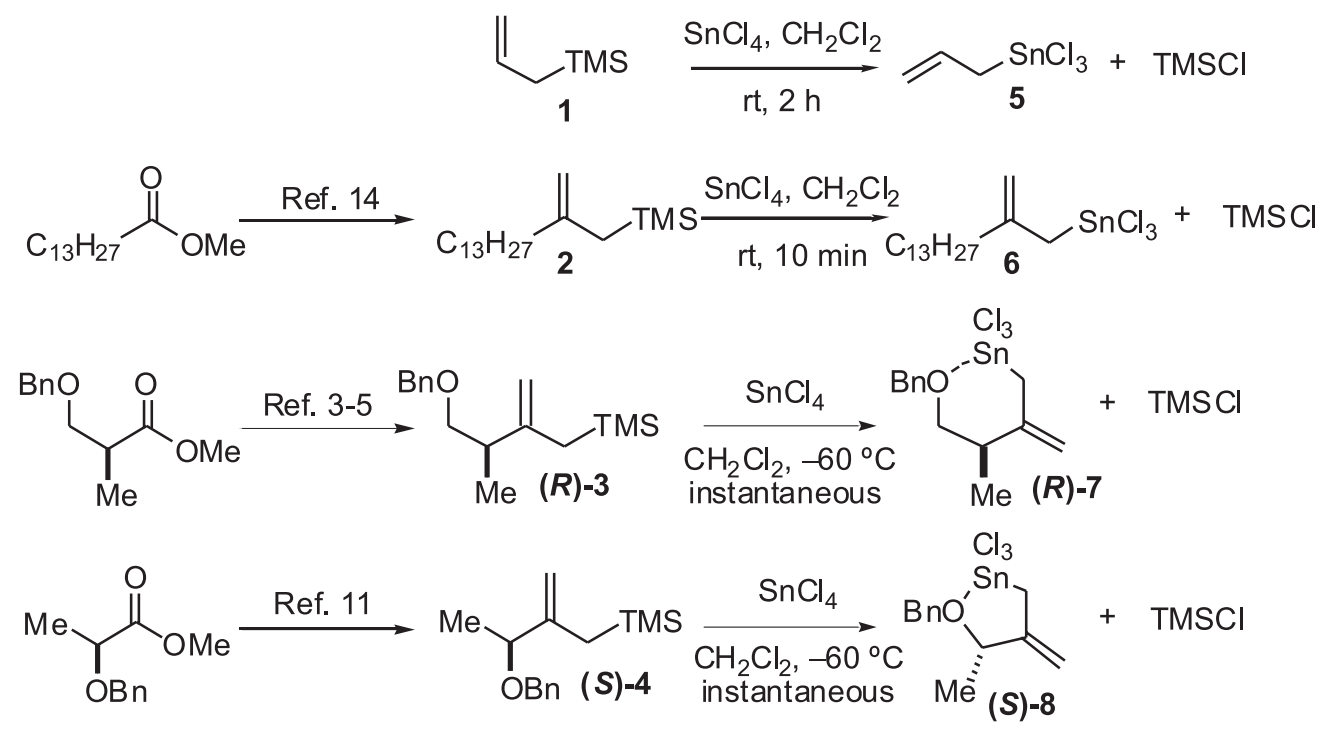

Scheme 1. $\mathrm{SiMe}_{3} / \mathrm{SnCl}_{3}$ exchange reaction of allylsilanes 1-4

5 when compared to the same signals for allylsilane $\mathbf{1}$ (Table 1$)^{5}$

Table 1. ${ }^{1} \mathrm{H}$ NMR chemical shifts $(\delta / \mathrm{ppm})$ for $\mathbf{1}$ and $\mathbf{5}$

\begin{tabular}{|c|c|c|c|c|}
\hline Compound & $\mathrm{H}_{1}$ & $\mathrm{H}_{2}$ & $\mathrm{H}_{3}$ & $\mathrm{H}_{4}$ \\
\hline 1 & 4.85 & 4.80 & 5.75 & 1.75 \\
\hline 5 & 5.45 & 5.35 & 5.95 & 3.25 \\
\hline
\end{tabular}

The same trend is observed for allylstannane $\mathbf{6}$ when compared to allylsilane $\mathbf{2}$ (Table 2). ${ }^{14}$

Table 2. ${ }^{1} \mathrm{H}$ NMR chemical shifts ( $\left.\delta / \mathrm{ppm}\right)$ for $\mathbf{2}$ and $\mathbf{6}^{14}$

\begin{tabular}{lcccc}
\hline & $\mathrm{H}_{1}$ & $\mathrm{H}_{2}$ & \\
\hline Compound & 4.52 & 4.60 & $\mathrm{H}_{3}$ \\
\hline $\mathbf{2}$ & 5.07 & 5.10 & 1.57 \\
$\mathbf{6}$ & & & \\
\hline
\end{tabular}

In the case of $(R)-7$, the deshielding of the hydrogens $\mathrm{H}_{6}$ to $\mathrm{H}_{9}$ in the ${ }^{1} \mathrm{H}$ NMR spectrum provides the best diagnostics (Table 3). The methylenic hydrogens $\mathrm{H}_{6}$ and $\mathrm{H}_{7}$ as well as the benzylic hydrogens $\mathrm{H}_{8}$ and $\mathrm{H}_{9}$ are too far away from the trichlorotin group to suffer from inductive effects. We believe that the deshielding observed for these hydrogens in $(R)-7$ is due to the internal coordination of this oxygen to tin, as proposed in Table $3 .^{5}$

Table 3. ${ }^{1} \mathrm{H}$ NMR chemical shifts $(\delta / \mathrm{ppm})$ for $(R)-3$ and $(R)-7^{5}$

\begin{tabular}{llllllllllllllll}
\hline & \\
\hline
\end{tabular}

A similar behavior is observed for allylstannane $(S)-8$ when compared to allylsilane $(S)-\mathbf{4}$ (Table 4).

Table 4. ${ }^{1} \mathrm{H}$ NMR chemical shifts $(\delta / \mathrm{ppm})$ for $(S)-\mathbf{4}$ and $(S)-\mathbf{8}$

\begin{tabular}{lccccccccccc}
\hline & & & & & & & \\
\end{tabular}

In addition, we have observed ${ }^{119} \mathrm{Sn}$ resonance signals at $-28 \mathrm{ppm}$ for allylstannane 5 (Figure 1 ). ${ }^{5}$ The tin chemical shift for allylstannane $(R)-7$ appeared at -187 
ppm and for allylstannane $(S)$-8 appeared at -169 ppm. The tin chemical shift for complexes $\mathbf{9}$ and $\mathbf{1 0}$ are -301 ppm and $-599 \mathrm{ppm}$, respectively, while for free $\mathrm{SnCl}_{4}$ it is $-156 \mathrm{ppm}$. We believe that tin chemical shifts are highly sensitive to oxygen bonding, as observed for $\mathbf{9}$ and $\mathbf{1 0}$, and the tin chemical shifts observed for $(R)-7$ and $(S)-\mathbf{8}$ are strong evidence in favor of the proposed complexed intermediates.

The corresponding chiral aldehydes $\mathbf{1 1}$ and $\mathbf{1 2}$ were prepared in excellent yields from methyl lactate (Figure 2). ${ }^{15,16}$ These substrates have been selected to be representative of the complex fragments that might be coupled in polyacetate and polypropionate-derived aldol-type reactions. For aldehydes 11, internal chelation is presumably prevented since, with few exceptions, silyl ethers are generally recognized for their poor coordinating and chelating abilities. ${ }^{17}$

In order to check the facial selectivities of aldehydes $\mathbf{1 1}$ and 12, we reacted them with achiral allyltrichlorostannanes 5 and 6. Achiral allyltrichlorostannane 5 reacted with chiral $\alpha$-alkoxy aldehyde $(S)-\mathbf{1 1}$ in $\mathrm{CH}_{2} \mathrm{Cl}_{2}$ at $-78{ }^{\circ} \mathrm{C}$ to give the corresponding 1,2-syn product $\mathbf{1 3}$ (anti-Felkin isomer) as the major isomer in $45 \%$ yield for the two-step sequence (preparation of the aldehyde from the ester and coupling reaction), with 60:40 diastereoselectivity (Scheme 2). ${ }^{18,19}$ Achiral allyltrichlorostannane $\mathbf{6}$ addition to the same aldehyde gave the corresponding 1,2-syn product 15 as the major isomer in $40 \%$ yield for the two-step sequence, again with 60:40 diastereoselectivity (Scheme 2). The stereoinduction observed in these reactions indicates that the intrinsic facial bias imposed by the resident $\alpha$-OTBS substituent results in preferential formation of the 1,2-syn diastereomer, with a small preference for the anti-Felkin type approach. ${ }^{19}$ One might project that the transition states of these reactions exhibit less charge separation than the aldol processes and are, accordingly, less subject to the electrostatic influence of the $\alpha$-OTBS function.

The relative stereochemistry for the major product 13 was confirmed by comparison with data described in the literature. ${ }^{20}$ In addition, we have also confirmed the relative stereochemistry for both $\mathbf{1 3}$ and $\mathbf{1 5}$ by analysis of the ${ }^{1} \mathrm{H}$ and ${ }^{13} \mathrm{C}$ NMR chemical shifts for both syn and anti isomers, as described by Heathoock ${ }^{21}$ and Hoffmann $^{22}$ for similar structures and applied to more complex substrates in this work. ${ }^{1} \mathrm{H}$ NMR and ${ }^{13} \mathrm{C}$ NMR spectroscopy are very useful tools to study substituent effects on the electronic environment of a given carbon, as well as to determine the relative stereochemistry in acyclic molecules, especially by analysis of the coupling constants $(J)$ in the corresponding ${ }^{1} \mathrm{H}$ NMR spectra. In the case of homoallylic alcohols $\mathbf{1 3 - 1 6}$, it is possible to assign the relative stereochemistry by ${ }^{1} \mathrm{H}$ and ${ }^{13} \mathrm{C} ~ \mathrm{NMR}$ analysis, as these compounds, by adopting an internal hydrogen-bonded conformation, exhibit magnetically distinct NMR environments.

The intramolecular hydrogen bond leads to a 5-member ring in which the substituents are trans $(\mathbf{1 3}$ and $\mathbf{1 5})$ or cis (14 and 16) and the predominance of hydrogen-bonded conformations should be reflected in different ${ }^{1} \mathrm{H}$ and ${ }^{13} \mathrm{C}$

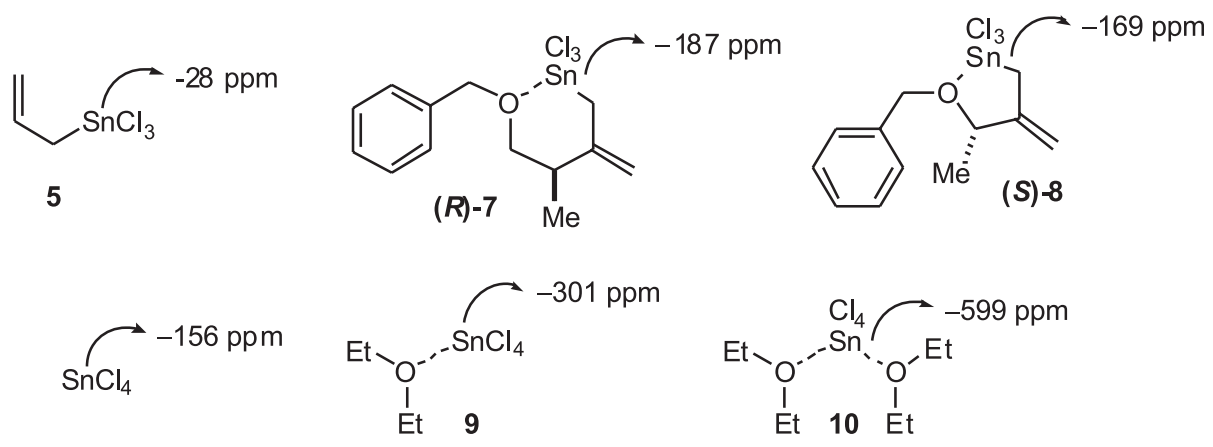

Figure 1. ${ }^{119} \mathrm{Sn}$ chemical shifts $\left(\mathrm{Me}_{4} \mathrm{Sn}(0.0 \mathrm{ppm})\right.$ is used as an internal reference)<smiles>CC(C=O)C(C)O[Sb]</smiles>

(S)-11<smiles>CC(C=O)C(C)O[Sb]</smiles>

(R)-11<smiles>CC(C)C(C)OCc1ccccc1</smiles>

(S)-12<smiles>C[C@@H](C=O)OCc1ccccc1</smiles>

(R)-12

Figure 2. Chiral aldehydes 11 and $\mathbf{1 2}$ 


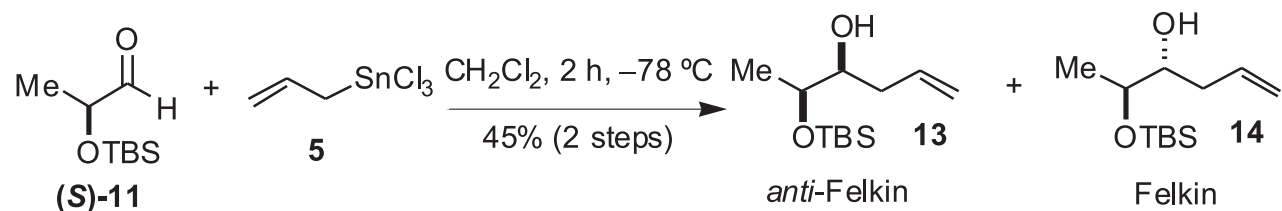

(S)-11

anti-Felkin

1,2-syn : 1,2-anti

ds $60: 40$

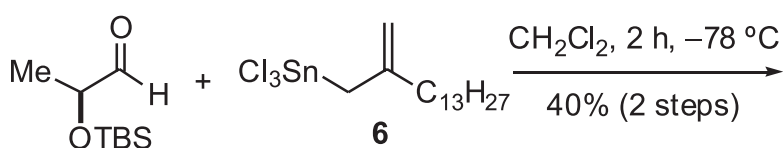

(S)-11

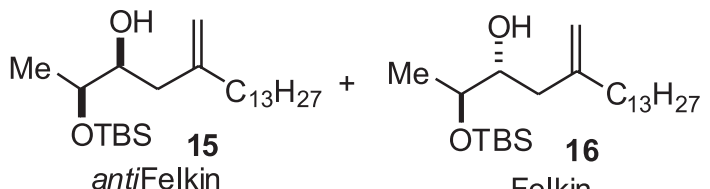

1,2-syn : 1,2-anti ds 60:40

Scheme 2. Addition of achiral allyltrichlorostannanes $\mathbf{5}$ and $\mathbf{6}$ to aldehyde $(S)-\mathbf{1 1}$

chemical shifts (Table 5). In fact, very strong experimental evidence for the existence of intramolecular hydrogen bonds in alcohols 13-16 comes from the observed chemical shifts in the ${ }^{1} \mathrm{H}$ NMR and ${ }^{13} \mathrm{C}$ NMR spectra measured in $\mathrm{CDCl}_{3}$ (Table 5). We have shown previously that the intrinsic low basicity of silyl ethers does not affect the capacity of the oxygen attached to the silicon atom to form intramolecular hydrogen bonds. ${ }^{23}$ The ${ }^{1} \mathrm{H}$ NMR spectra for compounds 13-16 are first order and the coupling constants $(J)$ and chemical shifts $(\delta)$ are directly measured from the spectra. The ${ }^{1} \mathrm{H}$ NMR chemical shifts of $\mathrm{H}_{\mathrm{a}}$ and $\mathrm{H}_{\mathrm{b}}$ for both 1,2-syn isomers $\mathbf{1 3}$ and $\mathbf{1 5}$ are more shielded than the corresponding signals for $\mathrm{H}_{\mathrm{a}}$ and $\mathrm{H}_{\mathrm{b}}$ in 1,2-anti homoallylic alcohols 14 and 16. For alcohol $13(\mathrm{R}=\mathrm{TBS})$, the ${ }^{1} \mathrm{H}$ chemical shifts are $3.38(\mathrm{Ha})$ and $3.70(\mathrm{Hb})$, showing a trans orientation between these two hydrogens. For alcohol 14, the ${ }^{1} \mathrm{H}$ chemical shifts are $3.56(\mathrm{Ha})$ and $3.78(\mathrm{Hb})$, showing a cis orientation between these two hydrogens. The same trend is observed for syn and anti homoallylic alcohols $\mathbf{1 5}$ and $\mathbf{1 6 .}$

In addition, the ${ }^{13} \mathrm{C}$ chemical shifts for the methyl group in syn compounds $\mathbf{1 3}$ and $\mathbf{1 5}$ are more deshielded when compared to the ${ }^{13} \mathrm{C}$ chemical shifts in $\mathbf{1 4}$ and $\mathbf{1 6}$.

We next examined the stereochemical impact of a benzyl-protecting group at the oxygen in position $\alpha$ to the carbonyl aldehyde. Before starting the study described in Scheme 3, we expected that under conditions favouring internal chelation, the carbonyl facial bias of aldehyde $(S)$ 12 should be highly predictable. In fact, that proved to be the case. The facial bias of aldehyde $(S)$-12 was determined after reaction with allyltrichlorostannane $\mathbf{5}$ in $\mathrm{CH}_{2} \mathrm{Cl}_{2}$ at $-78{ }^{\circ} \mathrm{C}$ to give a $97: 3$ mixture of diastereoisomers 17 and $\mathbf{1 8}$, in $45 \%$ yield over the two step sequence (Scheme 3 ).

This benzyl-protecting group imposes an intrinsic facial bias on the carbonyl that results in the formation of the
Table 5. ${ }^{1} \mathrm{H}$ NMR chemical shifts for homoallylic alcohols 13-16

13 $13\left(\mathrm{H}_{\mathrm{b}}\right)$


1,2-syn-dioxygen relationship. This leads to higher levels of diastereoselection when compared to the use of a TBS protecting group.

The 1,2-syn relative stereochemistry for adduct $\mathbf{1 7}$ was confirmed by comparison of ${ }^{1} \mathrm{H}$ - and ${ }^{13} \mathrm{C}$ NMR data as well as its optical rotation with literature values. ${ }^{24}$

Previous work from our laboratory showed that allyltrichlorostannane $(R)-7$ reacted with achiral aldehydes leading to the formation of 1,4-syn products as the major isomers (up to $>$ 95:5 diastereoselectivity). ${ }^{3-11}$

At this point we initiated the double stereodifferentiating studies involving allyltrichlorostannane $(R)-\mathbf{7}$ and chiral aldehydes $\mathbf{1 1}$ and $\mathbf{1 2}$. Addition of allyltrichlorostannane $(R)-\mathbf{7}$ to aldehyde $(S)-\mathbf{1 1}$ in $\mathrm{CH}_{2} \mathrm{Cl}_{2}$ at $-78{ }^{\circ} \mathrm{C}$ gave an 85:15 mixture of diastereoisomers $\mathbf{1 9}$ and 20, respectively, in $70 \%$ yield for the two-step sequence (Scheme 4).

Allyltrichlorostannane $(R)-7$ reacted with aldehyde (R)-11 to give 1,4-syn-1,2-syn product $\mathbf{2 1}$ as the major product in 55\% yield (2 steps), although with only 70:30 diastereoselectivity (Scheme 4).
The facial bias of this chiral allyltrichlorostannane is dominated by the $\alpha$-methyl stereocenter and tends to give the 1,4-syn isomer with $\mathrm{Si}$-face attack, but the facial bias of this particular aldehyde is to give the 1,2-syn product. We were surprised with the result with aldehyde $(R)-\mathbf{1 1}$ as we were expecting a higher level of diastereoselection in favor of the product $\mathbf{2 1}$.

The relative stereochemistry for the major products was determined after conversion to the corresponding dimethylacetonides (Scheme 5). Treatment of a mixture of 19 and 20 with TBAF in THF at room temperature gave diols $\mathbf{2 3}$ and $\mathbf{2 4}$ (67\% yield), which was followed by reaction with 2,2-dimethoxypropane and catalytic amounts of camphorsulphonic acid (CSA) to give acetonides $\mathbf{2 5}$ and $\mathbf{2 6}$ in $40 \%$ yield after purification by flash column chromatography (Scheme 5).

The cis-acetonide $\mathbf{2 5}$ comes from the 1,2-anti isomer $\mathbf{1 9}$ and the trans-acetonide $\mathbf{2 6}$ originates from the corresponding 1,2-syn isomer 20. The dimethyl groups $\left(\mathrm{Me}_{\mathrm{a}}\right.$ and $\left.\mathrm{Me}_{\mathrm{b}}\right)$ in both trans and cis dimethylacetonides are in different (average) chemical environments, giving

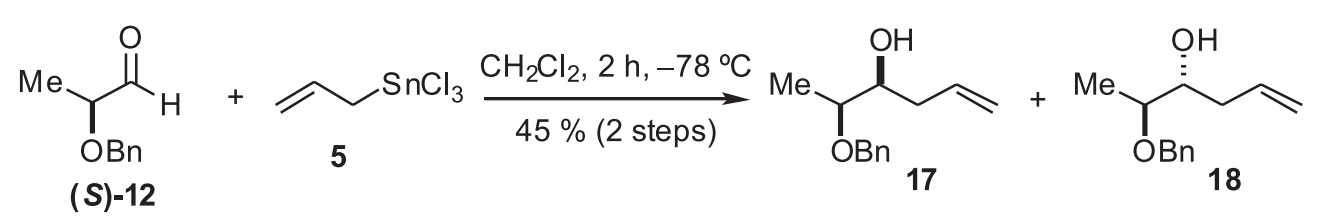

1,2-syn : 1,2-anti

ds $97: 3$

Scheme 3. Addition of achiral allyltrichlorostannane $\mathbf{5}$ to aldehyde $(S)-\mathbf{1 2}$

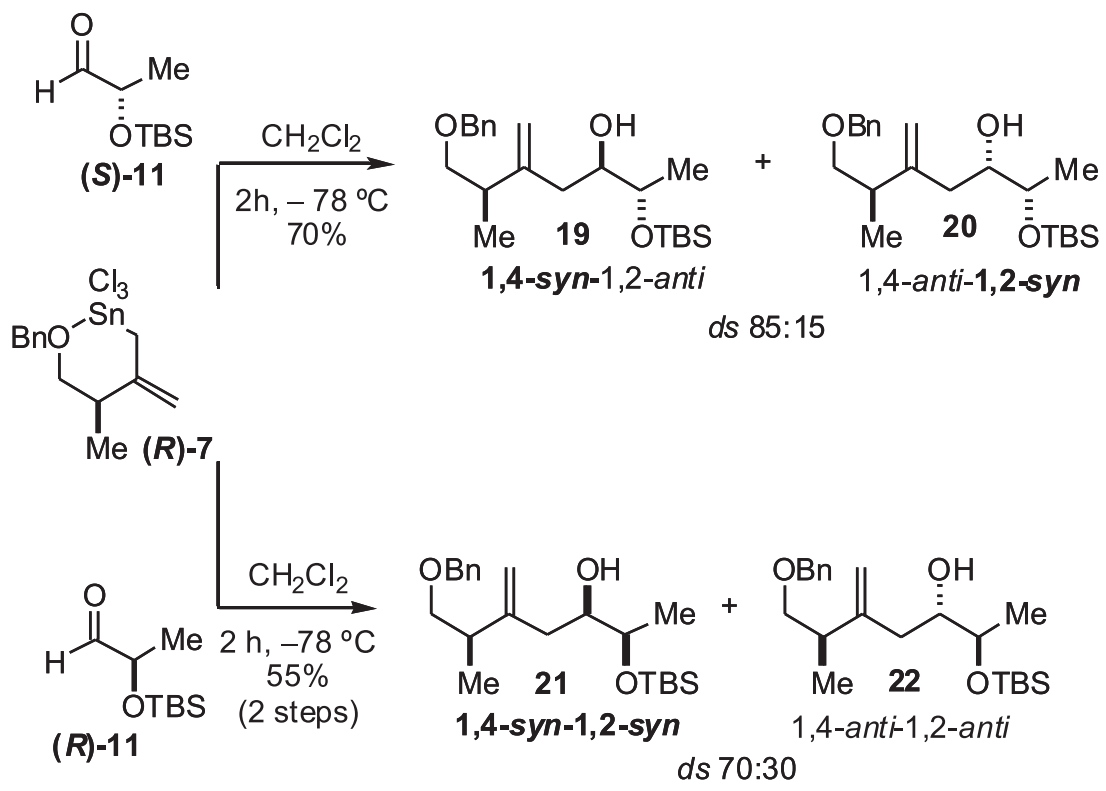

Scheme 4. Addition of allyltrichlorostannane (R)-7 to aldehydes $(S)$-11 and (R)-11 
rise to characteristic signals. As observed by Lombardo and coworkers ${ }^{25}$ the difference in chemical shifts of the methyl groups $\left(\mathrm{Me}_{\mathrm{a}}\right.$ and $\left.\mathrm{Me}_{\mathrm{b}}\right)$ in the five member ring of the dimethylacetonides is larger for the cis isomer (0.12$0.14 \mathrm{ppm}$ ) when compared to the trans isomer (0.01-0.04 ppm). ${ }^{25}$ In Figure 3 we can observe the partial ${ }^{1} \mathrm{H}$ NMR for cis and trans acetonides $\mathbf{2 5}$ and $\mathbf{2 6}$.

There is a larger difference in chemical shifts for the methyl groups $\left(\mathrm{Me}_{\mathrm{a}}\right.$ and $\left.\mathrm{Me}_{\mathrm{b}}\right)$ in the $\operatorname{cis}$ isomer $(\Delta \delta=0.12$ ppm) when compared to the chemical shifts for the same methyl groups of the trans isomer $(\Delta \delta=0.05 \mathrm{ppm})$. Based on this result we conclude that the 1,2-anti isomer $\mathbf{1 9}$ is the major product. ${ }^{26}$

The relative stereochemistry for compounds $\mathbf{2 1}$ and $\mathbf{2 2}$ was determined based on the same strategy (Scheme 6).

As before, we observed that the most intense signals come from the trans-acetonide 30, which in this case originates from the 1,2-syn adduct 21 (Figure 4).

We next moved to investigate the addition of allyltrichlorostannane $(R)-7$ to enantiomeric aldehydes $\mathbf{1 2}$ (Scheme 7). Allyltrichlorostannane $(R)-7$ reacted with chiral $\alpha$-benzyloxy-aldehyde $(S)$ - $\mathbf{1 2}$ in $\mathrm{CH}_{2} \mathrm{Cl}_{2}$ at $-78^{\circ} \mathrm{C}$ to give the corresponding 1,2-anti product $\mathbf{3 1}$ as the major product in $70 \%$ yield and with 85:15 diastereoselectivity (Scheme 7).

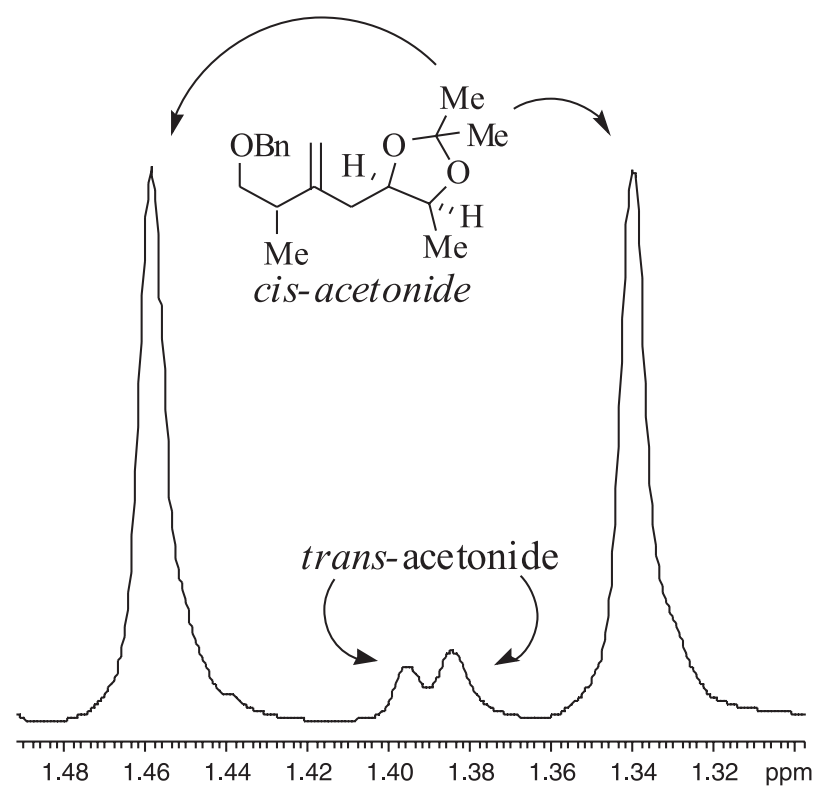

Figure 3. Partial ${ }^{1} \mathrm{H}$ NMR for acetonides 25 and $\mathbf{2 6}$<smiles>C=C(CC(O)C(C)[OH+]c1ccccc1)[C@H](C)COCc1ccccc1</smiles><smiles>C=C(CC(O)[C@@H](C)O)C(C)COCc1ccccc1</smiles>

19 (1,2-anti) and 20 (1,2-syn)

23 (1,2-anti) and 24 (1,2-syn)

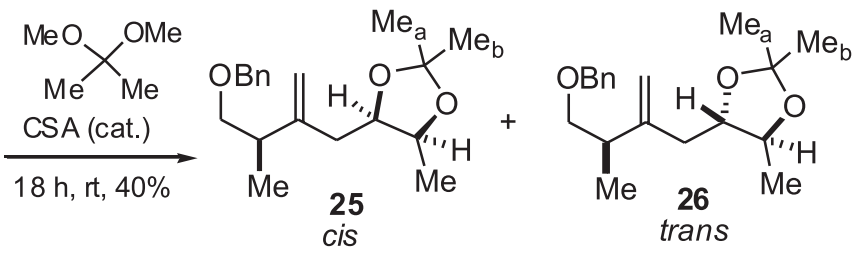

Scheme 5. Preparation of acetonides 25-(cis) and 26-(trans)<smiles></smiles>

21 (1,2-syn) and 22 (1,2-anti)

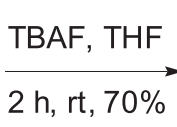<smiles>C=C(CC(C)C(C)OCc1ccccc1)[C@H](O)[C@@H](C)O</smiles>

27 (1,2-syn) and 28 (1,2-anti)

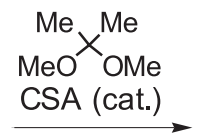

$18 \mathrm{~h}, \mathrm{rt}, 80 \%$<smiles>C=C(C[C@@H]1OC(C)([14CH3])O[C@H]1C)[C@H](C)COCc1ccccc1</smiles>

trans-acetonide<smiles>C=C(CC1OC(C)(C)O[C@H]1C)C(C)CBr</smiles>

cis-acetonide 


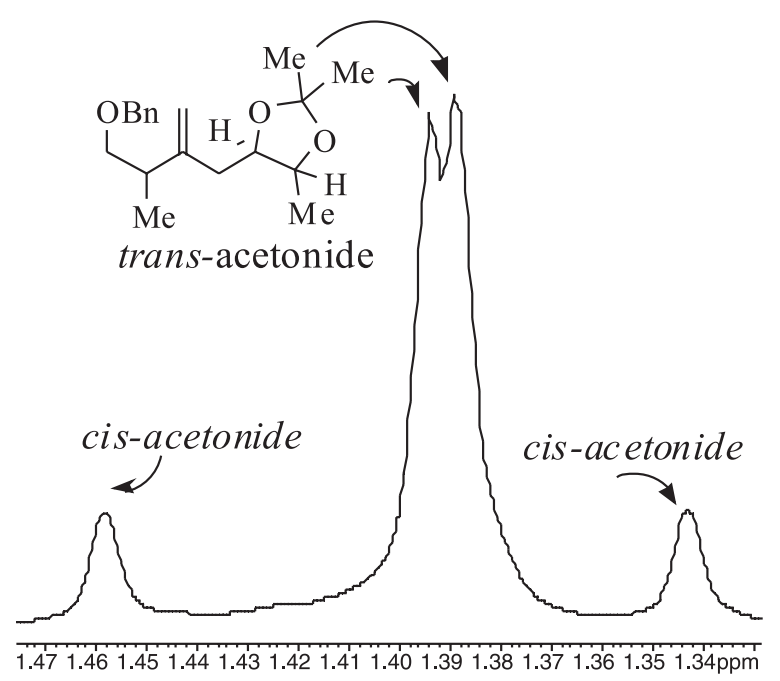

Figure 4. Partial ${ }^{1} \mathrm{H}$ NMR for acetonides 29 and $\mathbf{3 0}$

The coupling reaction between allyltrichlorostannane $(R)-7$ and aldehyde $(R)-\mathbf{1 2}$ in $\mathrm{CH}_{2} \mathrm{Cl}_{2}$ at $-78^{\circ} \mathrm{C}$ gave a $63: 37$ mixture of diastereoisomers $\mathbf{3 3}$ and $\mathbf{3 4}$, in $60 \%$ yield for the two-step sequence.

It is interesting to point out that as the facial bias of this aldehyde is to give the 1,2-syn products, we expected a matched case and much higher levels of diastereoselectivity in the reaction of $(R)-\mathbf{7}$ with $(R)$-12. Again, we were surprised to see that this was not the case.

The relative stereochemistries for both $\mathbf{3 1}$ and $\mathbf{3 3}$ were determined by applying the same methodology based on the ${ }^{13} \mathrm{C}$ NMR chemical shifts described before for 13-16 (Table 5). The 1,2-anti isomer is the major product as we

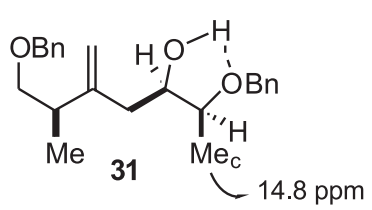

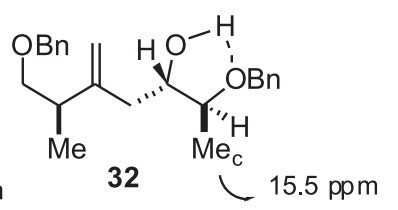

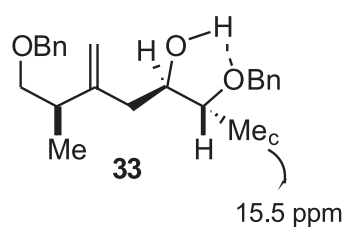

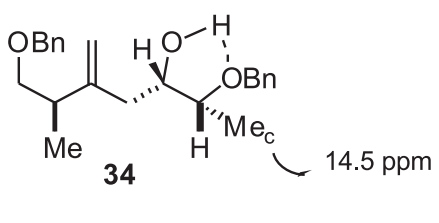

Figure 5. ${ }^{13} \mathrm{C}$ NMR chemical shifts for $\mathrm{Me}_{\mathrm{c}}$ in homoallylic alcohols 31-34

can observe from the ${ }^{13} \mathrm{C}$ NMR chemical shifts for the more shielded $\mathrm{Me}_{\mathrm{c}}$ (Figure 5). In the case of $\mathbf{3 1}$ and $\mathbf{3 2}$, the ${ }^{13} \mathrm{C}$ chemical shifts for $\mathrm{Me}_{\mathrm{c}}$ in $\mathbf{3 1}$ appears more shielded (14.8 ppm) when compared to 32 (15.5 ppm).

In the case of $\mathbf{3 3}$ and $\mathbf{3 4}$, we were able to confirm that the 1,2-syn is the major product, based on the ${ }^{13} \mathrm{C}$ chemical shifts for $\mathrm{Me}_{\mathrm{c}}$ in $\mathbf{3 3}$ (15.5 ppm) and $\mathbf{3 4}$ (14.5 ppm).

At this point, we turned our attention to the coupling reactions involving allyltrichlorostannane $(S)$-8. Addition of allyltrichlorostannane $(S)-\mathbf{8}$ to aldehyde $(S)$-11 gave a 65:35 mixture of diastereoisomers $\mathbf{3 5}$ and $\mathbf{3 6}$ in 60\% yield (2 steps) (Scheme 8).

We next examined the addition of the same allylstannane to the enantiomeric aldehyde $(R)$-11 affording a 75:25 mixture of isomers $\mathbf{3 7}$ and $\mathbf{3 8}$ in $47 \%$ yield for the twostep sequence.

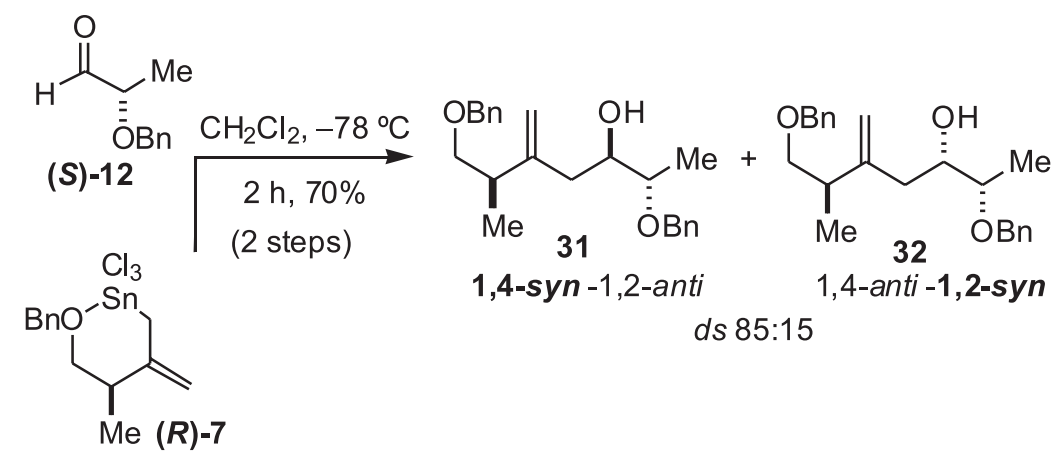

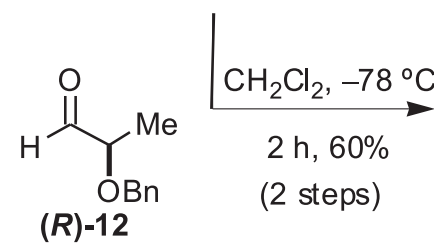<smiles>C=C(CC(O)C(OCc1ccccc1)[N+](=O)c1ccccc1)C(C)CO</smiles><smiles>C=C(COc1ccccc1)C(C)C[C@@H](O)C(C)OCc1ccccc1</smiles>

ds $63: 37$ 

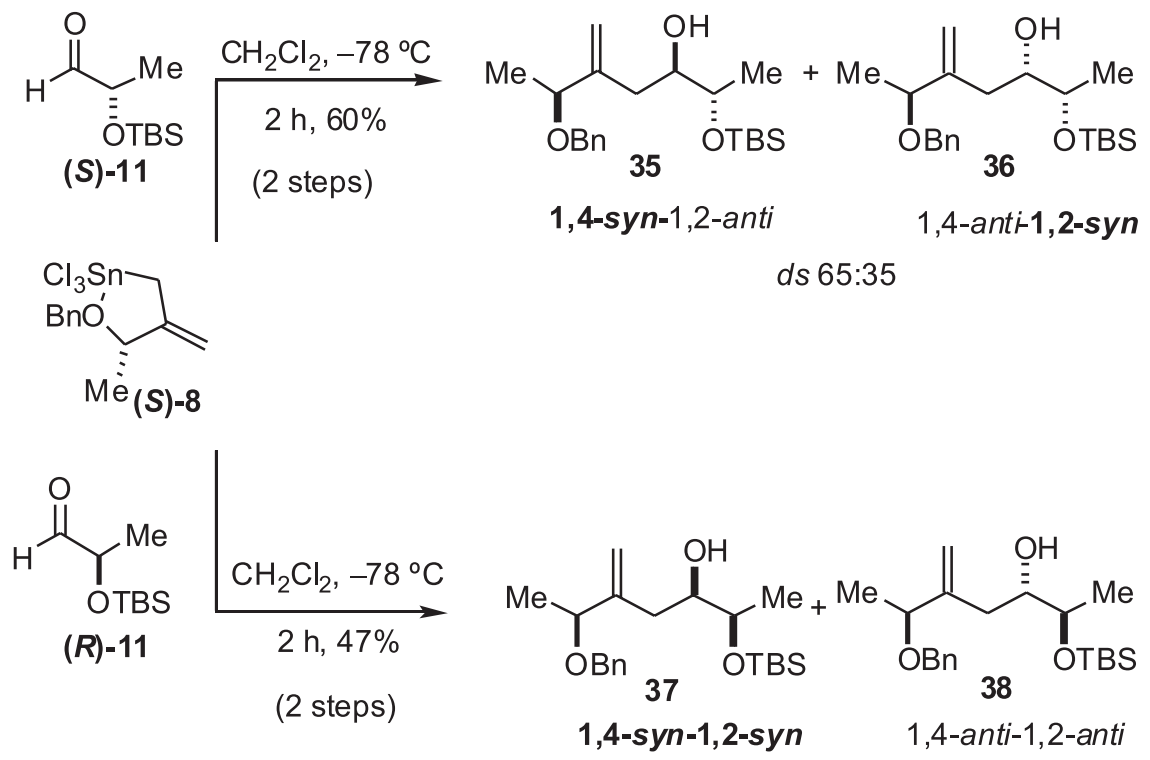

ds $75: 25$

Scheme 8. Addition of chiral allyltrichlorostannane $(S)-\mathbf{8}$ to chiral aldehydes $\mathbf{1 1}$

Again, these reactions with $\alpha$-OTBS aldehydes are characterized by poor levels of diastereoselectivity.

The relative stereochemistry for the major products was again determined based on the analysis of the ${ }^{13} \mathrm{C}$ NMR chemical shifts of the corresponding 5-membered dimethylacetonides (Scheme 9). Treatment of $\mathbf{3 5}$ and $\mathbf{3 6}$ with TBAF at $r$ followed by treatment of the corresponding diols under acidic conditions with 2,2-dimethoxypropane gave acetonides $\mathbf{4 1}$ and $\mathbf{4 2}$, respectively.

The ${ }^{1} \mathrm{H}$ NMR methyl resonances observed at 1.34 and 1.46 for $\mathbf{4 1}$ are characteristic of a cis-acetonide and ${ }^{1} \mathrm{H}$ NMR methyl resonances at 1.38 and 1.40 for $\mathbf{4 2}$ are consistent with a trans-acetonide (Figure 6). ${ }^{25}$

The same strategy was applied to $\mathbf{3 7}$ and $\mathbf{3 8}$, providing acetonides 45 and 46 (Scheme 10).

As can be seen from Figure 7, the trans-acetonide, which comes from the 1,2-syn adduct is the major isomer observed in this reaction.
Addition of allyltrichlorostannane $(S)-\mathbf{8}$ to aldehyde (S)-12 at $-78^{\circ} \mathrm{C}$ in $\mathrm{CH}_{2} \mathrm{Cl}_{2}$, gave an 80:20 diastereoisomeric mixture in favor of the 1,2-anti isomer $\mathbf{4 7}$ in $70 \%$ yield for the 2 steps (Scheme 11). Addition of allyltrichlorostannane $(S)-8$ to aldehyde $(R)-\mathbf{1 2}$ at $-78^{\circ} \mathrm{C}$ in $\mathrm{CH}_{2} \mathrm{Cl}_{2}$, led to a $60: 40$ diastereoisomeric mixture favoring the 1,2-syn isomer in $60 \%$ yield for the 2 steps (Scheme 11).

The selectivity in the latter case was somewhat disappointing, given the result observed in the reaction of aldehyde 12 with allyltrichlorostannane 5 (Scheme 3).

The relative stereochemistries for both $\mathbf{4 7}$ and $\mathbf{4 9}$ were determined by applying the same methodology described before for 13-16 (Table 5). The 1,2-anti isomer is the major product as can be observed from the ${ }^{13} \mathrm{C}$ NMR chemical shifts for the more shielded $\mathrm{Me}_{\mathrm{c}}$ (Figure 8). In the case of $\mathbf{4 9}$ and $\mathbf{5 0}$, the ${ }^{13} \mathrm{C}$ chemical shifts for $\mathrm{Me}_{\mathrm{c}}$ in 50 appears more shielded $(14.7 \mathrm{ppm})$ when compared to 49 (15.6 ppm).<smiles>C=C(Cc1ccccc1)C(O)C(C)O[Sb]</smiles>

35 (1,2-anti) and 36 (1,2-syn)<smiles>C=C(CC(O)[C@H](C)O)C(C)OCc1ccccc1</smiles>

39 (1,2-anti) and $\mathbf{4 0}(1,2-s y n)$<smiles>C=C(C[C@H]1OC(C)(C)O[C@H]1C)C(C)OC(C)C(C)OCc1ccccc1</smiles> 


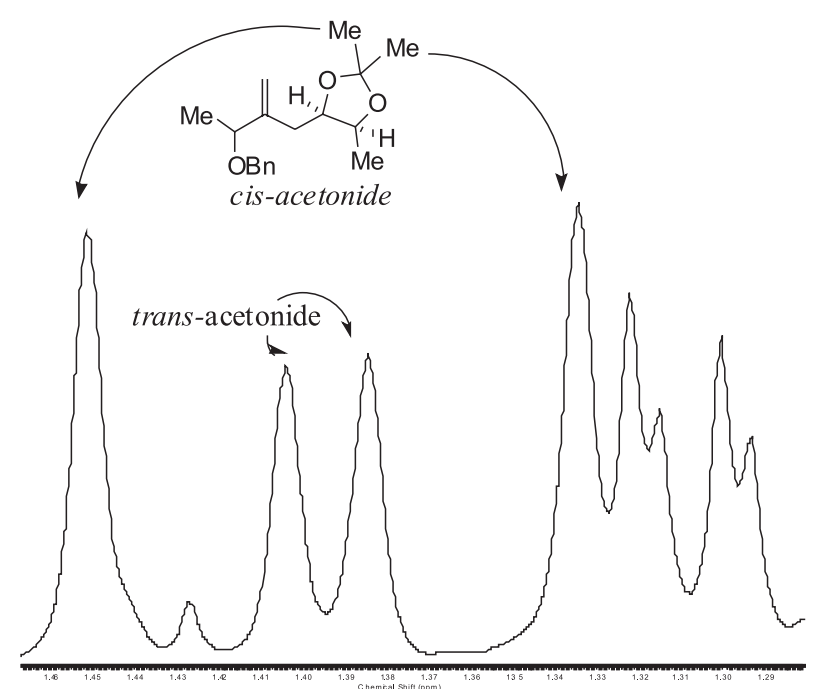

Figure 6. Partial ${ }^{1} \mathrm{H}$ NMR for acetonides 41-(cis) and 42-(trans)

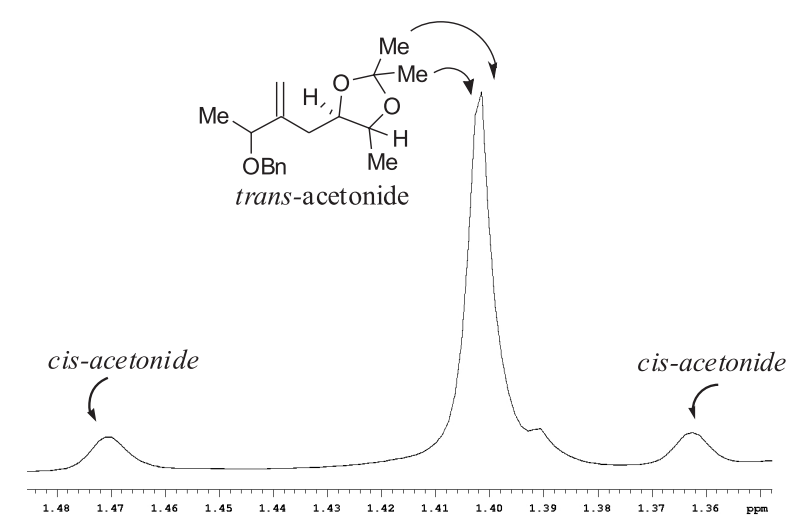

Figure 7. Partial ${ }^{1} \mathrm{H}$ NMR for acetonides 45 -(trans) and 46-(cis)<smiles>C=C(C[C@@H](O)C(=C)C[C@H](O)C(C)O)[C@H](C)OCc1ccccc1</smiles>

$37(1,2-s y n)$ and 38 (1,2-anti)

$43(1,2-s y n)$ and $44(1,2-a n t i)$

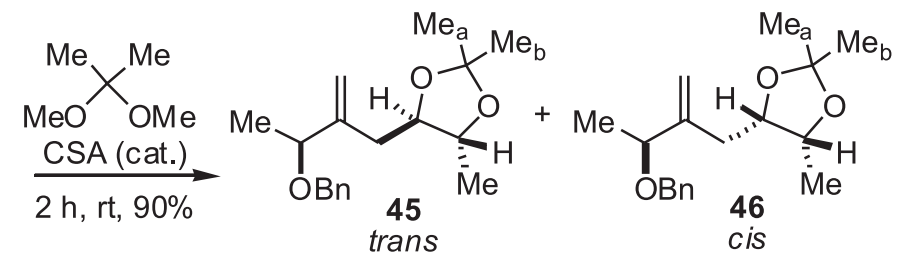

Scheme 10. Preparation of acetonides 45-(trans) and 46-(cis)

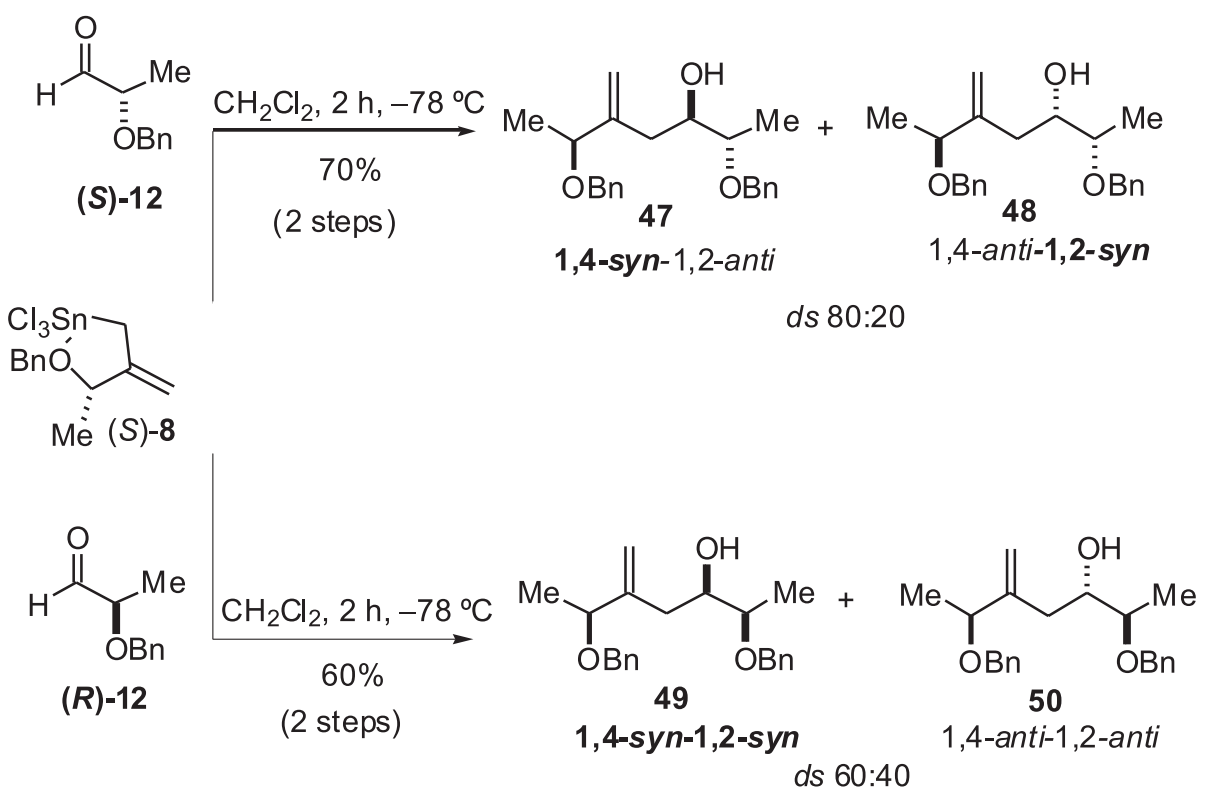

Scheme 11. Addition of allyltrichlorostannane $(S)-\mathbf{8}$ to chiral aldehydes $\mathbf{1 2}$ 


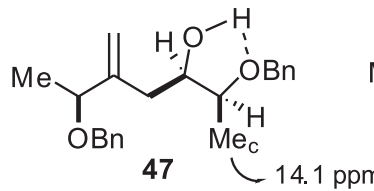

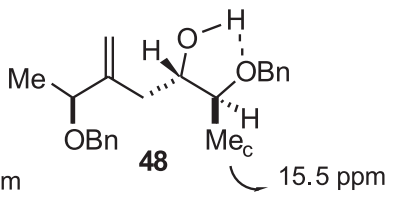<smiles>C=C(C[C@H]1OCOC1Cc1ccccc1)C(C)OCCCCCCc1ccccc1</smiles><smiles>C=C(C[C@@H]1O[CH][C@H](Cc2ccccc2)[C@H]1Cc1ccccc1)C(C)OCc1ccccc1</smiles>

Figure 8. ${ }^{1} \mathrm{H}$ NMR chemical shifts for homoallylic alcohols 47-50

\section{Conclusions}

The examples presented in this work show that the levels of $\pi$-facial selection are dependent on the absolute stereochemistries of the aldehydes as well as of the allyltrichlorostannanes. The results from these experiments suggest that the stereochemical relationships between the allyltrichlorostannane and aldehyde substituents may confer either a reinforcing (matched) or opposing (mismatched) facial bias on the carbonyl moiety. One possible reason for this result could be attributed to the involvement of energetically similar chair and twist-boat transition states that lead to diastereomeric product formation. Another possibility to consider in these reactions is that nonbonded interactions between the allyltrichlorostannane and $\alpha$ substituents on the aldehyde may not be significant in pericyclic transition states leading to either Felkin or anti-Felkin addition products. ${ }^{13}$ We believe that this chemistry is significant in the context of acyclic diastereoselection and will prove to be useful in the synthesis of more complex molecules, like polyacetate and polypropionate-derived natural products. $^{27,28}$

\section{Acknowledgments}

We are grateful to FAEP-UNICAMP, FAPESP (Fundação de Amparo à Pesquisa do Estado de São Paulo), CNPq (Conselho Nacional de Desenvolvimento Científico e Tecnológico) and INCT-INOFAR Proc. CNPq 573.564/2008-6 for financial support. We thank also Prof. Carol H. Collins for helpful suggestions about English grammar and style.

\section{Supplementary Information}

Available free of charge at http://jbcs.org.br, as PDF file.

\section{References}

1. Fleming, I.; Barbero, A.; Walter, D.; Chem. Rev. 1997, 97, 2063; Nishigaichi, Y.; Takuwa, A.; Naruta, Y.; Maruyama, K.; Tetrahedron 1993, 49, 7395; Panek, J. S.; Xu, F.; Rondon, A. C.; J. Am. Chem. Soc. 1998, 120, 4113; Zhu, B.; Panek, J. S.; Eur. J. Org. Chem. 2001, 9, 1701; Huang, H. B.; Spande, T. F.; Panek, J. S.; J. Am. Chem. Soc. 2003, 125, 626; Keck, G. E.; Abbott, D. E.; Tetrahedron Lett. 1984, 25, 1883; Maguire, R. J.; Mulzer, J.; Bats, J. W.; J. Org. Chem. 1996, 61, 6936; Denmark, S. E.; Stavenger, R. A.; J. Org. Chem. 1998, 63, 9524.

2. Trost, B. M.; Urabe, H.; J. Org. Chem. 1990, 55, 3982; Nishigaishi, Y.; Takuwa, A.; Jodai, A.; Tetrahedron Lett. 1991, 32, 2383; Almendros, P.; Gruttadauria, M.; Helliwell, M.; Thomas, E. J.; J. Chem. Soc. Perkin Trans. I 1997, 2549; Deka, D. C.; Helliwell, M.; Thomas, E. J.; Tetrahedron 2001, 57, 10017; Martin, N.; Thomas, E. J.; Tetrahedron Lett. 2001, 42, 8373; Kumar, P.; Thomas, E. J.; Tray, D. R.; J. Braz. Chem. Soc. 2001, 12, 623; Gruttadauria, M.; Thomas, E. J.; J. Chem. Soc. Perkin Trans. I 1995, 1469; Nishigaichi, Y.; Kuramoto, H.; Takuwa, A.; Tetrahedron Lett. 1995, 36, 3353.

3. Dias, L. C.; Giacomini, R.; J. Braz. Chem. Soc. 1998, 9, 357.

4. Dias, L. C.; Giacomini, R.; Tetrahedron Lett. 1998, 39, 5343.

5. Dias, L. C.; Meira, P. R. R.; Ferreira, E.; Org. Lett. 1999, 1, 1335. See also: "NMR Spectra and Structures of Organotin Compounds," V. S. Petrosyan, Progr. in NMR Spectr. 1978, 11, 115.

6. Dias, L. C.; Meira, P. R. R.; Synlett 2000, 37

7. Dias, L. C.; Ferreira, E.; Tetrahedron Lett. 2001, 42, 7159.

8. Dias, L. C.; Ferreira, A. A.; Diaz, G.; Synlett 2002, 1845.

9. Dias, L. C.; Diaz, G.; Ferreira, A. A.; Meira, P. R. R.; Ferreira, E.; Synthesis 2003, 603.

10. Dias, L. C.; Giacomini, R.; Meira, P. R. R.; Ferreira, E.; Ferreira, A. A.; Diaz, G.; dos Santos, D. R.; Steil, L. J.; Arkivoc 2003, 10,240 .

11. Dias, L. C.; dos Santos, D. R.; Steil, L. J.; Tetrahedron Lett. 2003, 44, 6861 .

12. We have recently described a very efficient and synthetically useful 1,4-anti-1,5-anti boron-mediated aldol reaction of chiral $\alpha$-methyl- $\beta$-alkoxy methyl ketone with achiral aldehydes: Dias, L. C.; Baú, R. Z.; de Sousa, M. A.; Zukerman-Schpector, J.; Org. Lett. 2002, 4, 4325 .

13. Denmark, S. E.; Wilson, T.; Willson, T. M.; J. Am. Chem. Soc. 1988, 110, 984; Denmark, S. E.; Weber, E. J.; Wilson, T.; Willson, T. M.; Tetrahedron 1989, 45, 1053; Denmark, S. E.; Almstead, N. G.; Tetrahedron 1992, 48, 5565; Denmark, S. E.; Almstead, N. G.; J. Am. Chem. Soc. 1993, 115, 3133.

14. Dias, L. C.; Fattori, J.; Perez, C. C.; Tetrahedron Lett. 2008, 49, 557; Dias, L. C.; Fattori, J.; Perez, C. C.; Oliveira, V. M.; Aguilar, A. M.; Tetrahedron 2008, 64, 5891.

15. Kim, D.; Lee, J.; Shim, P. J.; Lim, J. I.; Doi, T.; Kim, S.; J. Org. Chem. 2002, 67, 772. 
16. Although the diastereoselectivity of the reactions of these aldehydes with allyltrichlorostannanes depends on their enantiomeric purity, crude aldehydes were used in all of the studies described in the text.

17. Shambayati, S.; Schreiber, S. L.; Blake, J. F.; Wierschke, S. G.; Jorgensen, W. L.; J. Am. Chem. Soc. 1990, 112, 697.

18. The ratios were determined by ${ }^{1} \mathrm{H}$ and ${ }^{13} \mathrm{C}$-NMR spectroscopic analysis of the purified product mixture; The syn and antiproducts could not be separated and were characterized as mixtures; All of the percentage values represent data obtained from at least three individual trials.

19. Chérest, M.; Felkin, H.; Prudent, N.; Tetrahedron Lett. 1968, 18 , 2199; Anh, N. T.; Eisenstein, O.; Nouv. J. Chem. 1977, 1, 61; We use the "Felkin" descriptor to refer to the diastereomer predicted by the Felkin-Ahn paradigm. The "anti-Felkin" descriptor refers to diastereomers not predicted by this transition state model.

20. Batey, R. A.; Thadani, A. N.; Smil, D. V.; Lough, A. J.; Synthesis 2000, 7, 990 .

21. Heathcock, C. H.; Pirrung, M. C.; Sohn, J. E.; J. Org. Chem. 1979, 44, 4294.

22. Landmann, B.; Hoffmann, R. W.; Chem. Ber. 1987, 120, 331.

23. Dias, L. C.; Ferreira, M. A. B.; Tormena, C. F.; J. Phys. Chem. A 2008, 112, 232.

24. Sames, D.; Liu, Y.; De Young, L.; Polt, R.; J. Org. Chem. 1995, $60,2153$.

25. Lombardo, M.; Morganti, S.; Trombini, C.; J. Org. Chem. 2003, 68, 997.
26. Having confirmed the relative (syn or anti) relationship between allylstannane-derived stereogenic centers, the absolute stereochemistry of the newly formed hydroxyl substituent was determined by ascertaining its relationship to the stereocenter originating from the aldehydes, which are of known configuration.

27. All new compounds were isolated as chromatographically pure materials and exhibited acceptable ${ }^{1} \mathrm{H}-\mathrm{NMR},{ }^{13} \mathrm{C}-\mathrm{NMR}, \mathrm{IR}, \mathrm{MS}$, and HRMS spectral data.

28. General procedure for allyltrichlorostannane coupling reactions: To a solution of $2.5 \mathrm{mmol}$ of the corresponding allylsilane in $7 \mathrm{~mL}$ of dry $\mathrm{CH}_{2} \mathrm{Cl}_{2}$ at $-78^{\circ} \mathrm{C}$ was added $2.5 \mathrm{mmol}$ of $\mathrm{SnCl}_{4}$. The resulting solution was stirred at $-78^{\circ} \mathrm{C}$ for $30 \mathrm{~min}$ when $2.7 \mathrm{mmol}$ of aldehyde in $2 \mathrm{~mL}$ of $\mathrm{CH}_{2} \mathrm{Cl}_{2}$ was added. This mixture was stirred at $-78{ }^{\circ} \mathrm{C}$ for $1 \mathrm{~h}$ and quenched by the slow addition of $0.2 \mathrm{~mL}$ of $\mathrm{Et}_{3} \mathrm{~N}$, followed by $10 \mathrm{~mL}$ of saturated $\mathrm{NH}_{4} \mathrm{Cl}$ solution. The layers were separated and the aqueous layer was extracted with $\mathrm{CH}_{2} \mathrm{Cl}_{2}(2 \times 5 \mathrm{~mL})$. The combined organic layer was dried $\left(\mathrm{MgSO}_{4}\right)$, filtered, and concentrated in vacuo. Purification by flash chromatography on silica gel (30\% EtOAc/ hexanes) gave the corresponding homoallylic alcohols.

Received: February 9, 2009

Web Release Date: April 30, 2009

FAPESP helped in meeting the publication costs of this article. 


\title{
Addition of Chiral and Achiral Allyltrichlorostannanes to Chiral $\alpha$-Alkoxy Aldehydes
}

\author{
Luiz C. Dias*, Tatiana Augusto, Carla C. Perez and Leonardo J. Steil \\ Chemistry Institute, State University of Campinas, UNICAMP, P.O. Box 6154, 13084-971 Campinas-SP, Brazil
}

General Informations: All reactions were carried out under an atmosphere of argon or nitrogen in flamedried glassware with magnetic stirring. Dichloromethane, triethylamine, 2,6-lutidine, diisopropylamine, dimethylformamide and $\mathrm{N}$-methylpyrrolidone were distilled from $\mathrm{CaH}_{2}$. Dimethyl sulfoxide was distilled under reduced pressure from calcium hydride and stored over molecular sieves. THF and toluene were distilled from sodium/benzophenone ketyl. Petrol refers to the fraction boiling between $40-60^{\circ} \mathrm{C}$. Purification of reaction products was carried out by flash chromatography using silica-gel (230-400 mesh). Analytical thin layer chromatography was performed on silica gel 60 and GF (5-40 $\mu$ m thickness) plates. Visualization was accomplished with UV light and anisaldehyde, ceric ammonium nitrate stain or phosphomolybdic acid followed by heating or $\mathrm{I}_{2}$ staining. ${ }^{1} \mathrm{H}-\mathrm{NMR}$ spectra were taken in $\mathrm{CDCl}_{3}$ at $300 \mathrm{MHz}$ or at 500 $\mathrm{MHz}$ spectrometer and are reported in ppm using solvent as an internal standard $\left(\mathrm{CDCl}_{3}\right.$ at $\left.7.26 \mathrm{ppm}\right)$ unless otherwise indicated. Data are reported as (ap = apparent, $\mathrm{s}=$ singlet, $\mathrm{d}=$ doublet, $\mathrm{t}=$ triplet, $\mathrm{q}=$ quartet, quint $=$ quintet, sext $=$ sextet, ap $\mathrm{t}=$ apparent triplet, $\mathrm{m}=$ multiplet, $\mathrm{br}=$ broad, $\mathrm{td}$ $=$ triplet of doublets, quint $\mathrm{d}=$ quintet of doublets, coupling constant(s) in Hz; integration. Proton-decoupled ${ }^{13} \mathrm{C}-\mathrm{NMR}$ spectra were taken in $\mathrm{CDCl}_{3}$ at $75 \mathrm{MHz}$ spectrometer and are recorded in ppm using solvent as an internal standard $\left(\mathrm{CDCl}_{3}\right.$ at $\left.77.0 \mathrm{ppm}\right)$ unless otherwise indicated.

Allylsilanes 2-4 (General Procedure): In a 3-necked $500 \mathrm{~mL}$ round bottomed flask powdered $\mathrm{CeCl}_{3} .7 \mathrm{H}_{2} \mathrm{O}(15.44$ $\mathrm{g}, 41.4 \mathrm{mmol}$ ) was heated under vacuum ( 1 Torr) at $160^{\circ} \mathrm{C}$ for $12 \mathrm{~h}$ with vigorous stirring, resulting in the formation of a mobile white solid. The reaction flask was flushed with argon and allowed to cool to rt when anhydrous THF $(65 \mathrm{~mL})$ was added to the vigorously stirred anhydrous cerium(III) chloride forming a uniform white suspension, which was kept under stirring for $2 \mathrm{~h}$. During this time, a separate three-necked $100 \mathrm{~mL}$ flask, fitted with a condenser and a pressure-equalizing dropping funnel, was charged

*e-mail: 1dias@iqm.unicamp.br with Mg turnings ( $1 \mathrm{~g}, 41.4 \mathrm{mmol}$ ), and the whole apparatus was flame dried under a flow of argon. To this flask was added dropwise a solution of $\mathrm{ClCH}_{2} \mathrm{SiMe}_{3}(5.8 \mathrm{~mL}, 41.4$ mmol) in anhydrous THF $(27 \mathrm{~mL})$. This mixture was stirred for $3 \mathrm{~h}$ until almost all of the $\mathrm{Mg}$ had dissolved. The anhyd $\mathrm{CeCl}_{3}$ suspension was now cooled to $-78^{\circ} \mathrm{C}$. To this suspension was added dropwise the previously prepared Grignard reagent, forming an off-white suspension, which was stirred at $-78^{\circ} \mathrm{C}$ for $2 \mathrm{~h}$. At this time, a solution of the corresponding ester $(13.8 \mathrm{mmol})$ in anhydrous THF (8 $\mathrm{mL}$ ) was added to the Grignard-cerium chloride complex dropwise over $5 \mathrm{~min}$, and the resulting mixture was warmed gradually to r.t. When consumption of the starting ester was complete, as determined by TLC $(3 \mathrm{~h})$, the resulting grey solution was cooled to $0{ }^{\circ} \mathrm{C}$ and quenched by the addition of a sat. aq solution of $\mathrm{NH}_{4} \mathrm{Cl}(30 \mathrm{~mL})$. The organic layer was separated, and the aqueous layer was extracted with $\mathrm{Et}_{2} \mathrm{O}$ $(2 \times 50 \mathrm{~mL})$. The combined organic layers were washed with brine $(2 \times 50 \mathrm{~mL})$ and dried $\left(\mathrm{MgSO}_{4}\right)$. The solvent was removed under reduced pressure to give a slightly yellow liquid that was dissolved in $\mathrm{CH}_{2} \mathrm{Cl}_{2}(100 \mathrm{~mL})$. To this flask was added Amberlyst $15(1.0 \mathrm{~g})$ and this mixture was stirred at rt until complete consumption of starting material. The resin was then removed by filtration and washed with $\mathrm{CH}_{2} \mathrm{Cl}_{2}(100 \mathrm{~mL})$. The solvent was removed under reduced pressure to give allylsilanes $\mathbf{2 - 4}$.

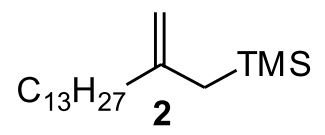

Trimethyl(2-methylenepentadecyl)silane (2): yellow oil; Yield: 68\%; TLC: $\mathrm{R}_{f} 0.75$ (EtOAc/hexane 20\%); IR (Film): v 3072, 2953, 2926, 2854, 1633, 1466, 1248, 1157 $\mathrm{cm}^{-1} ;{ }^{1} \mathrm{H}$ NMR $\left(\mathrm{CDCl}_{3}, 300 \mathrm{MHz}\right): \delta 0.04(\mathrm{~s}, 9 \mathrm{H}), 0.91(\mathrm{t}$, $J=7.0 \mathrm{~Hz}, 3 \mathrm{H}$ ), 1.29 (brs, 20H), 1.39-1.49 (m, 2H), 1.57 (s, 2H), 1.97 (t, $J=7.0 \mathrm{~Hz}, 2 \mathrm{H}), 4.52(\mathrm{brs}, 1 \mathrm{H}), 4.60(\mathrm{~d}, J$ $=1.0 \mathrm{~Hz}, 1 \mathrm{H}) ;{ }^{13} \mathrm{C} \mathrm{NMR}\left(\mathrm{CDCl}_{3}, 75 \mathrm{MHz}\right): \delta 2.1\left(\mathrm{CH}_{3}\right)$, 14.2 $\left(\mathrm{CH}_{2}\right), 22.5\left(\mathrm{CH}_{3}\right), 22.8\left(\mathrm{CH}_{2}\right), 27.8\left(\mathrm{CH}_{2}\right), 29.4\left(\mathrm{CH}_{2}\right)$, $29.6\left(\mathrm{CH}_{2}\right), 29.8\left(\mathrm{CH}_{2}\right), 32.0\left(\mathrm{CH}_{2}\right), 37.9\left(\mathrm{CH}_{2}\right), 109.4$ $\left(\mathrm{CH}_{2}\right), 146.2\left(\mathrm{C}_{0}\right)$. 
<smiles>C=C(CC(C)C)C(C)COc1ccccc1</smiles>

(R)-(4-(benzyloxy)-3-methyl-2-methylenebutyl) trimethylsilane (3): Yield: $88 \%$; $\mathrm{R} f=0.38$ (EtOAc/hexanes $5 \%) ;[\alpha]_{\mathrm{D}}^{22}:+12.6\left(c 1.3, \mathrm{CHCl}_{3}\right)$; IR (film) $v\left(\mathrm{~cm}^{-1}\right): 3069$, 3030, 2957, 2851, 1632, 1497, 1453, 1414, 1364, 1247, $1158,1097,1031,952,852,735,696,634 \mathrm{~cm}^{-1}$; ${ }^{1} \mathrm{H}$ NMR $\left(\mathrm{CDCl}_{3}, 300 \mathrm{MHz}\right) \delta(\mathrm{ppm}): 0.03(\mathrm{~s}, 9 \mathrm{H}), 1.04(\mathrm{~d}, J=6.8$ $\mathrm{Hz}, 3 \mathrm{H}), 1.46(\mathrm{~d}, J=13.6 \mathrm{~Hz}, \mathrm{lH}), 1.52(\mathrm{~d}, J=13.6 \mathrm{~Hz}$, $1 \mathrm{H}), 2.28(\mathrm{~m}, 1 \mathrm{H}), 3.26(\mathrm{dd}, J=9.3,8.3 \mathrm{~Hz}, 1 \mathrm{H}), 3.53(\mathrm{dd}$, $J=9.3,5.4 \mathrm{~Hz}, 1 \mathrm{H}), 4.52(\mathrm{~d}, J=12.1 \mathrm{~Hz}, 1 \mathrm{H}), 4.53(\mathrm{~d}, J=$ $12.1 \mathrm{~Hz}, \mathrm{lH}), 4.62(\mathrm{~s}, 1 \mathrm{H}), 4.64(\mathrm{~s}, 1 \mathrm{H}), 7.25-7.40(\mathrm{~m}, 5 \mathrm{H})$; ${ }^{13} \mathrm{C}$ NMR $\left(\mathrm{CDCl}_{3}, 75 \mathrm{MHz}\right), \delta(\mathrm{ppm}):-1.3,17.1,26.6$, 41.0, 72.9, 75.0, 106.5, 127.4, 127.5, 128.3, 138.7, 149.7; Elemental analysis: calcd. for $\mathrm{C}_{16} \mathrm{H}_{26} \mathrm{OSi}$ : $\mathrm{C}, 73.22 \%$; $\mathrm{H}$, 9.98\%; found: C, $73.15 \%$; $\mathrm{H}, 10.02 \%$.

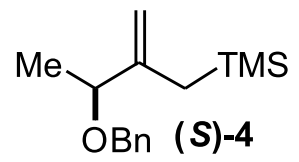

(S)-(3-(benzyloxy)-2-methylenebutyl)trimethylsilane (4): $\mathrm{R} f=0.34(\mathrm{EtOAc} / \mathrm{hexanes} 5 \%) ;[\alpha]_{\mathrm{D}}^{22}:+12.6$ (c 1.3, $\mathrm{CHCl}_{3}$ ); IR (film) $v\left(\mathrm{~cm}^{-1}\right): 3068,3023,2951,1720,1603$, 1495, 1454, 1248, 1093; ${ }^{\mathrm{H}} \mathrm{NMR}\left(\mathrm{CDCl}_{3}, 300 \mathrm{MHz}\right), \delta$ (ppm): 0.08 (s, 9H), 1.30 (d, $J=6.6 \mathrm{~Hz}, 3 \mathrm{H}), 1.48$ (d, $J=$ $14.5 \mathrm{~Hz}, 1 \mathrm{H}), 1.62(\mathrm{~d}, J=14.5 \mathrm{~Hz}, 1 \mathrm{H}), 3.84(\mathrm{q}, J=6.6$ $\mathrm{Hz}, 1 \mathrm{H}), 4.35(\mathrm{~d}, J=11.7 \mathrm{~Hz}, 1 \mathrm{H}), 4.57(\mathrm{~d}, J=11.7 \mathrm{~Hz}$, $1 \mathrm{H}), 4.80(\mathrm{~s}, 1 \mathrm{H}), 5.00(\mathrm{~s}, 1 \mathrm{H}), 7.25-7.40(\mathrm{~m}, 5 \mathrm{H}) ;{ }^{13} \mathrm{C} \mathrm{NMR}$ $\left(\mathrm{CDCl}_{3}, 75 \mathrm{MHz}\right), \delta$ (ppm): $-0.8,20.6,21.1,70.0,78.8$, 108.7, 127.2, 127.5, 128.2, 138.8, 147.6.

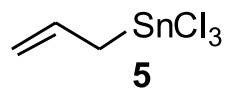

Allyltrichlorostannane (5): ${ }^{1} \mathrm{H}$ NMR $\left(\mathrm{CDCl}_{3}, 300\right.$ MHz) $\delta(\mathrm{ppm}): 3.06(\mathrm{~d}, J=5,2 \mathrm{~Hz}, 1 \mathrm{H}), 5.33(\mathrm{~d}, J=5.6$ $\mathrm{Hz}, 1 \mathrm{H}), 5.40(\mathrm{~d}, J=6.6 \mathrm{~Hz}, 1 \mathrm{H}), 5.97(\mathrm{~m}, 1 \mathrm{H}) ;{ }^{13} \mathrm{C} \mathrm{NMR}$ $\left(\mathrm{CDCl}_{3}, 75 \mathrm{MHz}\right) \delta$ (ppm): 35.0, 121.0, 127.0. Obs. The signal at $0.45 \mathrm{ppm}$ corresponds to TMSCl.<smiles>C=C([18OH])C[SeH]</smiles>

Trichloro(2-methylenepentadecyl)stannane (6): ${ }^{1} \mathrm{H}$ NMR $\left(\mathrm{CDCl}_{3}, 300 \mathrm{MHz}\right): \delta 0.89$ (t, $\left.J=6.0 \mathrm{~Hz}, 3 \mathrm{H}\right), 1.30$ (brs, 20H), $1.51(\mathrm{~m}, 2 \mathrm{H}), 2.14(\mathrm{t}, J=8.0 \mathrm{~Hz}, 2 \mathrm{H}), 3.15$ (s, $2 \mathrm{H}), 5.07$ (brs, $1 \mathrm{H}), 5.10$ (brs, $1 \mathrm{H})$. Obs. The signal at 0.45 ppm corresponds to TMSCl.<smiles>C=C1C[Sn](Cl)OCC1C</smiles>

(R)-(4-(benzyloxy)-3-methyl-2-methylenebutyl) trichlorostannane (7): ${ }^{1} \mathrm{H}$ NMR $\left(\mathrm{CDCl}_{3}, 300 \mathrm{MHz}\right) \delta$ (ppm): 0.95 (d, $J=7.0 \mathrm{~Hz}, 3 \mathrm{H}), 2.48(\mathrm{~m}, \mathrm{lH}), 3.19$ (d, $J=$ $11.2 \mathrm{~Hz}, 1 \mathrm{H}), 3.36(\mathrm{~d}, J=11.2 \mathrm{~Hz}, 1 \mathrm{H}), 3.53(\mathrm{dd}, J=9.9$, $8.4 \mathrm{~Hz}, 1 \mathrm{H}), 3.70(\mathrm{dd}, J=9.9,4.4 \mathrm{~Hz}, 1 \mathrm{H}), 4.71(\mathrm{~d}, J=13.2$ $\mathrm{Hz}, 1 \mathrm{H}), 4.77(\mathrm{~d}, J=13.2 \mathrm{~Hz}, 1 \mathrm{H}), 5.04(\mathrm{~s}, 1 \mathrm{H}), 5.18(\mathrm{~s}, 1 \mathrm{H})$, 7.30-7.50 (m, 5H). Obs. The signal at $0.45 \mathrm{ppm}$ corresponds to $\mathrm{TMSCl} ;{ }^{13} \mathrm{C} \mathrm{NMR}\left(\mathrm{CDCl}_{3}, 75 \mathrm{MHz}\right) \delta(\mathrm{ppm}): 15.7,39.9$, 42.7, 73.0, 74.5, 114.6, 127.5, 128.3, 128.7, 138.7, 144.0. Obs. The signal at $3.6 \mathrm{ppm}$ corresponds to TMSCl.<smiles>C=C1C[Sn](Cl)O[Bi]1C</smiles>

( $S$ ) - ( 3 - (benzyloxy ) - 2 - methylenebutyl) trichlorostannane (8): ${ }^{1} \mathrm{H} \mathrm{NMR}\left(\mathrm{CDCl}_{3}, 300 \mathrm{MHz}\right.$, $\left.-60{ }^{\circ} \mathrm{C}\right) \delta(\mathrm{ppm}): 1.28(\mathrm{~d}, J=6.6 \mathrm{~Hz}, 3 \mathrm{H}), 2.91(\mathrm{~d}, J=$ $14.5 \mathrm{~Hz}, 1 \mathrm{H}), 3.05(\mathrm{~d}, J=14.5 \mathrm{~Hz}, 1 \mathrm{H}), 4.17(\mathrm{q}, J=6.6$ $\mathrm{Hz}, 1 \mathrm{H}), 4.68(\mathrm{~d}, J=11.7 \mathrm{~Hz}, 1 \mathrm{H}), 5.01(\mathrm{~s}, 1 \mathrm{H}), 5.05(\mathrm{~s}$, $1 \mathrm{H}), 5.10(\mathrm{~d}, J=11.7 \mathrm{~Hz}, 1 \mathrm{H}), 7.20-7.40(\mathrm{~m}, 5 \mathrm{H})$. Obs. The signal at $0.45 \mathrm{ppm}$ corresponds to TMSCl.

Homoallylic Alcohols (General Procedure): To a solution of the corresponding allylsilane $(1.5 \mathrm{mmol})$ in $\mathrm{CH}_{2} \mathrm{Cl}_{2}(5 \mathrm{~mL})$ at $\mathrm{rt}$ was added $\mathrm{SnCl}_{4}(1.1 \mathrm{mmol})$. The resulting solution was stirred at $\mathrm{rt}$ for $2 \mathrm{~h}$ and then cooled to $-78^{\circ} \mathrm{C}$ when a solution of aldehyde $(1.2 \mathrm{mmol})$ in $\mathrm{CH}_{2} \mathrm{Cl}_{2}$ $(2 \mathrm{~mL})$ was added. This mixture was stirred for $2 \mathrm{~h}$ at -78 ${ }^{\circ} \mathrm{C}$ and quenched by the slow addition of a sat. aq solution of $\mathrm{NaHCO}_{3}(5 \mathrm{~mL})$ followed by $\mathrm{CH}_{2} \mathrm{Cl}_{2}(5 \mathrm{~mL})$. The layers were separated and the aqueous layer was extracted with $\mathrm{CH}_{2} \mathrm{Cl}_{2}(2 \times 5 \mathrm{~mL})$. The combined organic layers were dried $\left(\mathrm{MgSO}_{4}\right)$, filtered, and concentrated in vacuo. Purification by flash chromatography on silica gel (30\% EtOAc-hexane) gave the corresponding homoallylic alcohols.

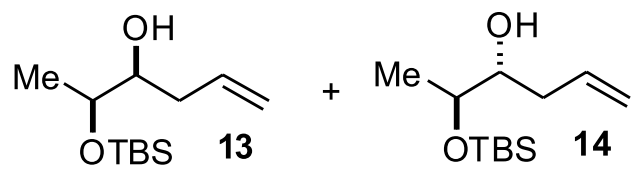

(2S,3S)-2-(tert-butyldimethylsilyloxy)hex-5-en-3-ol (13) and (2S,3R)-2-(tert-butyldimethylsilyloxy)hex-5-en3-ol (14): Yield: $45 \%$; $\mathrm{R} f=0.26$ (EtOAc/hexanes 5\%); IR (film) $v\left(\mathrm{~cm}^{-1}\right): 3568,3468,2956,2957,2932,2858,1641$, 
1473, 1389, 1074, 1005, 968, 912, 777; ${ }^{1} \mathrm{H} \mathrm{NMR}\left(\mathrm{CDCl}_{3}\right.$, $300 \mathrm{MHz}) \delta$ (ppm): $0.08(\mathrm{~s}, 3 \mathrm{H}), 0.09$ (s, 3H), 0.91 (s, 9H), $1.17(\mathrm{~d}, J=6.2 \mathrm{~Hz}, 3 \mathrm{H}), 2.18-2.32(\mathrm{~m}, 2 \mathrm{H}), 3.33-3.43(\mathrm{~m}$, $1 \mathrm{H}), 3.70-3.82(\mathrm{~m}, 1 \mathrm{H}), 5.01-5.16(\mathrm{~m}, 2 \mathrm{H}), 5.81-5.59(\mathrm{~m}$, 1H). Minor isomer: $0.07(\mathrm{~s}, 3 \mathrm{H}), 1.12(\mathrm{~d}, J=6.2 \mathrm{~Hz}, 3 \mathrm{H})$, 3.53-3.60 (m, 1H), 3.76-3.82 (m, 1H); ${ }^{13} \mathrm{C} \mathrm{NMR}\left(\mathrm{CDCl}_{3}, 75\right.$ $\mathrm{MHz}) \delta(\mathrm{ppm}):-4.7,-4.0,18.2,20.2,25.9,38.1,70.9,75.2$, 116.8, 135.1; Minor isomer (14): 17.5, 36.8, 74.5, 117.2.<smiles>C=C([14CH3])CC(O)C(C)O[Se-]</smiles>

$(2 S, 3 S)-2$ - (tert -butyldimethylsilyloxy $)-5$ methyleneoctadecan-3-ol (15) and $(2 S, 3 R)-2-($ tertbutyldimethylsilyloxy)-5-methyleneoctadecan-3-ol (16): Yield: 40\%; Rf $=0.36$ (EtOAc/hexane 5\%); IR (film) v $\left(\mathrm{cm}^{-1}\right): 3465,3067,2957,2930,2857,1645,1371,1255$, $1092,835,775 ;{ }^{1} \mathrm{H} \mathrm{NMR}\left(\mathrm{CDCl}_{3}, 300 \mathrm{MHz}\right) \delta$ (ppm): 0.08( $\mathrm{s}, 6 \mathrm{H}), 0.88$ (m, 3H), 0.89 (s, 9H), $1.16(\mathrm{~d}, J=6.0 \mathrm{~Hz}, 3 \mathrm{H})$, 1.25 (brs, 22H), 1.36-1.49 (m, 2H), 2.01-2.18 (m, 2H), 3.49 $(\mathrm{dq}, J=4.4 \mathrm{~Hz}, 6.6 \mathrm{~Hz}, 1 \mathrm{H}), 3.66-3.75(\mathrm{~m}, 1 \mathrm{H}), 4.81$ (d, $J$ $=4.7 \mathrm{~Hz}, 2 \mathrm{H})$; Minor isomer: $0.06(\mathrm{~s}, 6 \mathrm{H}), 1.12(\mathrm{~d}, J=6.0$ $\mathrm{Hz}, 3 \mathrm{H}), 3.56-3.66(\mathrm{~m}, 1 \mathrm{H}) ;{ }^{13} \mathrm{C} \mathrm{NMR}\left(\mathrm{CDCl}_{3}, 63 \mathrm{MHz}\right) \delta$ (ppm): -4.8, -4.1, 14.1, 18.0, 22.7, 25.8, 27.7, 29.4, 29.7, 31.9, 71.0, 73.4, 111.3. Minor isomer: 20.0, 29.7, 73.0.<smiles>C=CC[C@@H](O)[C@@H](C)OCc1ccccc1</smiles>

$(2 S, 3 S)$-2-(benzyloxy)hex-5-en-3-ol (17) and (2S,3R)2-(benzyloxy)hex-5-en-3-ol (18): Yield: 40\%; $\mathrm{R} f=0.44$ (EtOAc/hexane 10\%); IR (film) $v\left(\mathrm{~cm}^{-1}\right): 3566,3453,3062$, 3030, 2969, 2871, 1603, 1645, 1454, 1072, 1028, 993, 914, 737, 698; ${ }^{1} \mathrm{H} \mathrm{NMR}\left(\mathrm{CDCl}_{3}, 500 \mathrm{MHz}\right) \delta(\mathrm{ppm}): 1.21(\mathrm{~d}, J$ $=6.0 \mathrm{~Hz}, 3 \mathrm{H}), 2.15-2.26(\mathrm{~m}, 1 \mathrm{H}), 2.31-2.40(\mathrm{~m}, 1 \mathrm{H}), 3.44$ (apqt, $J=6.2 \mathrm{~Hz}, 1 \mathrm{H}), 3.52(\mathrm{ddd}, J=4.4 \mathrm{~Hz}, 6.2 \mathrm{~Hz}, 7.7$ $\mathrm{Hz}, 1 \mathrm{H}), 4.38(\mathrm{~d}, J=11.7 \mathrm{~Hz}, 1 \mathrm{H}), 4.66(\mathrm{~d}, J=11.7 \mathrm{~Hz}$, $1 \mathrm{H}), 5.09$ (d, $J=9.5 \mathrm{~Hz}, 1 \mathrm{H}), 5.12(\mathrm{~d}, J=20.3 \mathrm{~Hz}, 1 \mathrm{H})$, 5.87 (ddt, $J=7.3 \mathrm{~Hz}, 9.5 \mathrm{~Hz}, 20.5 \mathrm{~Hz}$ ), 7.26-7.38 (m, 5H). Minor isomer: $1.15(\mathrm{~d}, J=6.2 \mathrm{~Hz}, 3 \mathrm{H}) ;{ }^{13} \mathrm{C} \mathrm{NMR}\left(\mathrm{CDCl}_{3}\right.$, $63 \mathrm{MHz}) \delta$ (ppm): 15.4, 37.5, 71.0, 74.2, 117.2, 127.8, 128.4, 134.7, 138.3. Minor isomer: 13.8, 36.9, 70.7.

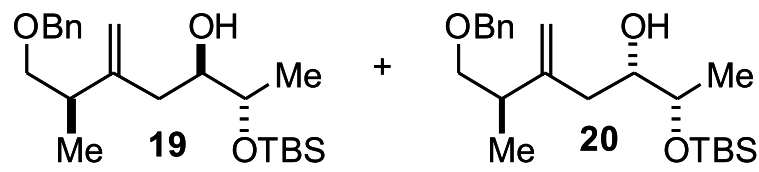

$(2 S, 3 R, 6 R)-7$ - ( b e n z y l ox y ) - 2 - ( t e r $t$ butyldimethylsilyloxy)-6-methyl-5-methyleneheptan- 3-ol (19) and $(2 S, 3 S, 6 R)-7-($ benzyloxy)-2-(tertbutyldimethylsilyloxy)-6-methyl-5-methyleneheptan3-ol (20): Yield: 55\%; Rf =0.28 (EtOAc/hexanes 10\%); IR (film) $v\left(\mathrm{~cm}^{-1}\right): 3465,3067,2957,2930,2857,1645,1371$, 1092, 835, 775; ${ }^{1} \mathrm{H} \mathrm{NMR}\left(\mathrm{CDCl}_{3}, 300 \mathrm{MHz}\right) \delta$ (ppm): 0.08 (s, 6H), 0.9 (s, 9H), $1.07(\mathrm{~d}, J=7.0 \mathrm{~Hz}, 3 \mathrm{H}), 1.15(\mathrm{~d}, J=$ $6.2 \mathrm{~Hz}, 3 \mathrm{H}), 2.07(\mathrm{dd}, J=9.2,14.3 \mathrm{~Hz}, 1 \mathrm{H}), 2.31(\mathrm{dd}, J$ $=4.0,14.3 \mathrm{~Hz}, 1 \mathrm{H}), 2.50(\mathrm{~m}, 1 \mathrm{H}), 3.39(\mathrm{dd}, J=6.6,9.2$ $\mathrm{Hz}, 2 \mathrm{H}), 3.42(\mathrm{dd}, J=7.0,9.2 \mathrm{~Hz}, 2 \mathrm{H}), 3.63(\mathrm{~m}, 1 \mathrm{H}), 3.72$ (m, 1H), $4.93(\mathrm{~s}, 1 \mathrm{H}), 4.95(\mathrm{~s}, 1 \mathrm{H}), 7.26-7.32(\mathrm{~m}, 5 \mathrm{H}) ;{ }^{13} \mathrm{C}$ $\mathrm{NMR}\left(\mathrm{CDCl}_{3}, 75 \mathrm{MHz}\right) \delta$ (ppm): -4.6, -4.2, 17.5, 18.1, 18.7, 25.9, 38.7, 39.3, 71.4, 73.0, 73.5, 74.5, 111.6, 127.4, 128.2, 138.2, 149.0 .

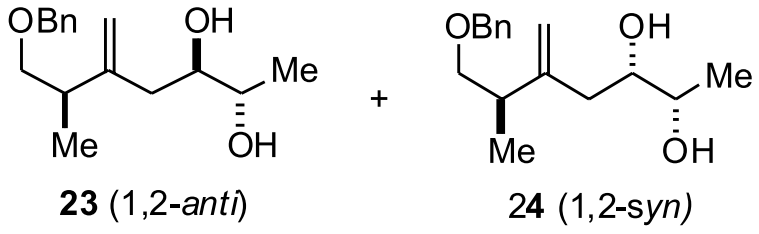

( $2 S, 6 R$ ) - 7 - ( b e n z y lox y ) - 6 - m e t h y l - 5 methyleneheptane-2,3-diols (23) and (24): Yield: 67\%; $R f=0.26\left(\right.$ EtOAc/hexanes 50\%); ${ }^{1} \mathrm{H}$ NMR $\left(\mathrm{CDCl}_{3}, 300\right.$ MHz) $\delta$ (ppm): 1.02 (d, $J=7.0 \mathrm{~Hz}, 3 \mathrm{H}), 1.17$ (d, $J=6.2$ $\mathrm{Hz}, 3 \mathrm{H}), 2.13-2.29$ (m, 2H), 2.51-2.55 (m, 1H), 3.39-3.51 (m, 2H), 3.70-3.77 (m, 1H), 3.84-3.92 (m, 1H) 4.51 (s, 2H), $5.00(\mathrm{~s}, 2 \mathrm{H}) ; 5.30$ (s, 2H), 7.28-7.38 (m, 5H); ${ }^{13} \mathrm{C} \mathrm{NMR}$ $\left(\mathrm{CDCl}_{3}, 75 \mathrm{MHz}\right) \delta(\mathrm{ppm}): 17.5,36.8,39.0,69.9$, 72.0, $73.1,74.3,112.8,127.8,128.2,137.8,148,8$.

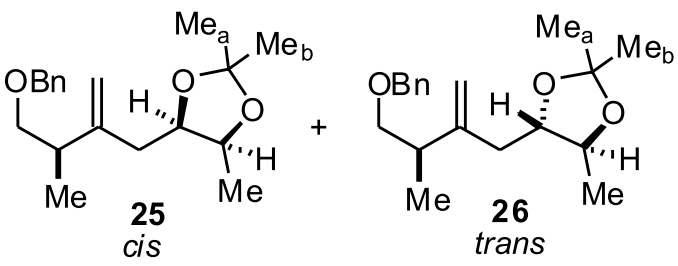

$(4 R, 5 S)$ - 4 - ( ( R ) - 4 - (benzyloxy) - 3 - methyl-2 methylenebutyl)-2,2,5-trimethyl-1,3-dioxolane (25) and (4S,5S)-4-((R)-4-(benzyloxy)-3-methyl-2methylenebutyl)-2,2,5-trimethyl-1,3-dioxolane (26): $R f=0.72$ (EtOAc/hexanes 20\%); IR (film) $\vee\left(\mathrm{cm}^{-1}\right)$ : 3047, 2986, 2934, 2872, 1645, 1454, 1377, 1223, 1080; ${ }^{1} \mathrm{H} \operatorname{NMR}\left(\mathrm{CDCl}_{3}, 300 \mathrm{MHz}\right) \delta(\mathrm{ppm}): 1.02(\mathrm{~d}, J=6.4$ $\mathrm{Hz}, 3 \mathrm{H}), 1.12$ (d, $J=6.7 \mathrm{~Hz}, 3 \mathrm{H}), 1.31$ (s, 3H), 1.49 (s, $3 \mathrm{H}), 2.07$ (dd, $J=4.9,15.6 \mathrm{~Hz}, 1 \mathrm{H}), 2.34(\mathrm{dd}, J=8.4$, $15.6 \mathrm{~Hz}, 1 \mathrm{H}), 2.07$ (st, $J=6.7 \mathrm{~Hz}, 1 \mathrm{H}), 3.25$ (dd, $J=7.2$, $8.9 \mathrm{~Hz}, 1 \mathrm{H}), 3.43(\mathrm{dd}, J=5.8,8.9 \mathrm{~Hz}, 1 \mathrm{H}), 4.09$ (qt, $J=$ $6.4 \mathrm{~Hz}, 1 \mathrm{H}), 4.21(\mathrm{dt}, J=5.3,8.5 \mathrm{~Hz}, 1 \mathrm{H}), 4.33(\mathrm{~s}, 2 \mathrm{H})$, $4,93(\mathrm{~d}, J=13.7 \mathrm{~Hz}, 2 \mathrm{H}), 7.28-7.38(\mathrm{~m}, 5 \mathrm{H}) ;{ }^{13} \mathrm{C} \mathrm{NMR}$ (benzene-d6, $75 \mathrm{MHz}) \delta$ (ppm): 16.1, 17.4, 26.0, 28.9, 35.9, 40.4, 73.1, 74.0, 75.1, 76.9, 107.4, 110.7, 126.5, $127.6,128.5,139.3,149.3$. 
<smiles>C=C(C[C@H](O)C(C)[OH+]C(=C)C(C)COCc1ccccc1)C(C)COCc1ccccc1</smiles>

$(2 R, 3 R, 6 R)$ - 7 - ( b e n z y l ox y ) - 2 - ( t e r $t$ butyldimethylsilyloxy)-6-methyl-5-methyleneheptan3-ol (21) and $(2 R, 3 S, 6 R)-7-($ benzyloxy $)-2-($ tert butyldimethylsilyloxy)-6-methyl-5-methyleneheptan3-ol (22): $R f=0.53$ (hexanes: EtOAc, 95:05); IR (film) v $\left(\mathrm{cm}^{-1}\right): 3463,3031,2950,2857,1645,1559,1497,1455$, $1255,1092,895 ;{ }^{1} \mathrm{H} \mathrm{NMR}\left(\mathrm{CDCl}_{3}, 300 \mathrm{MHz}\right) \delta(\mathrm{ppm})$ : 0.09 (s, 3H), 0.09 (s, 3H), 0.91 (s, 9H), 1.09 (d, $J=7.0$ $\mathrm{Hz}, 3 \mathrm{H}), 1.16$ (d, $J=6.2 \mathrm{~Hz}, 3 \mathrm{H}) 2.03-2.35(\mathrm{~m}, 2 \mathrm{H}) ; 2.50$ (qt, $J=7.0 \mathrm{~Hz}, 1 \mathrm{H}), 3.32-3.39(\mathrm{~m}, 1 \mathrm{H}), 3.45-3.64(\mathrm{~m}$, 2H), 3.72-3.80 (m, 1H), 4.52 (s, 2H), 4.91 (s, 1H), 4.94 (s, 1H), 7.33-7.34 (m, 5H).Minor isomer: $0.07(\mathrm{~s}, 3 \mathrm{H}), 0.08$ (s, 3H), 0.90 (s, 9H), 1.11 (d, $J=2.2 \mathrm{~Hz}, 3 \mathrm{H}) ;{ }^{13} \mathrm{C}$ NMR $\left(\mathrm{CDCl}_{3}, 75 \mathrm{MHz}\right) \delta(\mathrm{ppm}):-4.8,-4.2,17.4,18.0,18.3$, 19.7, 25.8, 38.9, 39.4, 71.0, 73.0, 79.7, 74.6, 111.4, 127.5, 128.3, 138.4, 149.2. Minor isomer: 17.2, 38.5, 39.6, 71.4, 74.8, 79.7, 74.6, 111.8 .

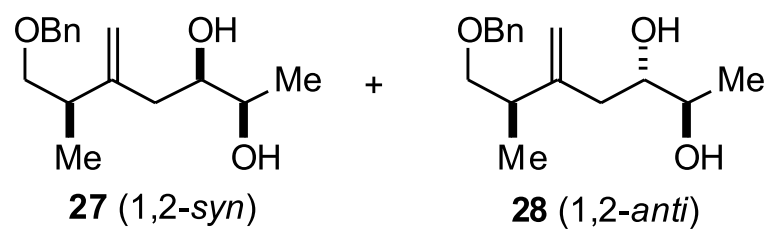

( $2 R, 6 R$ ) - 7 - ( b e nzy lox y ) - 6 - met h y l - 5 methyleneheptane-2,3-diol (27) and (28): $R f=0.65$ (EtOAc/hexanes 50\%); ${ }^{1} \mathrm{H} \mathrm{NMR}\left(\mathrm{CDCl}_{3}, 500 \mathrm{MHz}\right) \delta(\mathrm{ppm})$ : $1.01(\mathrm{~d}, J=7.0 \mathrm{~Hz}, 3 \mathrm{H}), 1.18(\mathrm{~d}, J=6.0 \mathrm{~Hz}, 3 \mathrm{H}) ; 2.02-2.57$ (m, 3H); 3.87-3.34 (m, 4H) 4.49 (d, J=2.3 Hz, 1H), 4.97 (d, $J=2.3 \mathrm{~Hz}, 1 \mathrm{H}), 7.28-736(\mathrm{~m}, 5 \mathrm{H})$. Minor isomer: $1.08(\mathrm{~d}, J$ $=7.0 \mathrm{~Hz}, 3 \mathrm{H}), 1.15(\mathrm{~d}, J=6.0 \mathrm{~Hz}, 3 \mathrm{H}) ;{ }^{13} \mathrm{C} \mathrm{NMR}\left(\mathrm{CDCl}_{3}\right.$, $125 \mathrm{MHz}) \delta$ (ppm): 17.8, 19.0, 38.5, 40.1, 70.7, 73.2, 74.8, 113.0, 127.8, 128.4, 138.0, 148.8. Minor isomer: 17.3, 37.3, $39.7,69.9,75.0,112.7,127.7,128.4$.

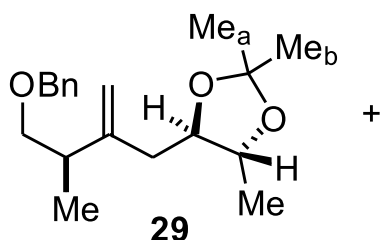

trans-acetonide

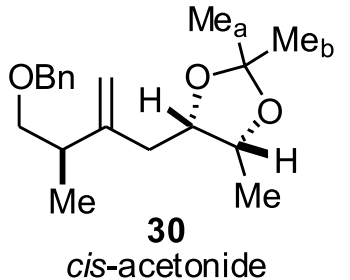

cis-acetonide
$(4 R, 5 R)$ - 4 - ( ( R ) - 4 - ( benzyloxy ) - 3 - methyl2-methylenebutyl)-2,2,5-trimethyl-1,3-dioxolane (29) and $(4 S, 5 R)-4-((R)-4-(b e n z y l o x y)-3-m e t h y l-2-$ methylenebutyl)-2,2,5-trimethyl-1,3-dioxolane (30): Yield: 50\%; $R f=0.38$ (EtOAc/hexanes 5\%); IR (film) v $\left(\mathrm{cm}^{-1}\right):$ 3055, 2986, 2936, 2874, 1645, 1454, 1379, 1090, 898, 842; ${ }^{1} \mathrm{H}$ NMR $\left(\mathrm{C}_{6} \mathrm{D}_{6}, 500 \mathrm{MHz}\right) \delta(\mathrm{ppm}): 1.10(\mathrm{~d}$,
$J=6.1 \mathrm{~Hz}, 3 \mathrm{H}), 1.13(\mathrm{~d}, J=7.0 \mathrm{~Hz}, 3 \mathrm{H}), 1,40(\mathrm{~s}, 6 \mathrm{H})$, $2.13(\mathrm{dd}, J=4.0,15.0 \mathrm{~Hz}, 1 \mathrm{H}), 2.32(\mathrm{dd}, J=7.6,15.0$ $\mathrm{Hz}, 1 \mathrm{H}), 2.55$ (apsex, $J=6.4 \mathrm{~Hz}, 1 \mathrm{H}), 3.23$ (dd, $J=7.3$, $8.8 \mathrm{~Hz}, 1 \mathrm{H}), 3.42(\mathrm{dd}, J=5.8,8.8 \mathrm{~Hz}, 1 \mathrm{H}), 3.62(\mathrm{dq}, J=$ 5.8, 8.2 Hz, 1H), 3.68-3.72 (m,1H), 4.33 (s, 2H), 4.91 (s, 2H), $4.91(\mathrm{~s}, 1 \mathrm{H}), 5.02(\mathrm{~s}, 1 \mathrm{H}), 7.15-7.31(\mathrm{~m}, 5 \mathrm{H})$. Minor isomer: $1.11(\mathrm{~d}, J=6.0 \mathrm{~Hz}, 3 \mathrm{H}), 1.31(\mathrm{~s}, 3 \mathrm{H}), 1.49(\mathrm{~s}$, $3 \mathrm{H}), 2.06(\mathrm{dd}, \mathrm{J}=4.6,15.4 \mathrm{~Hz}, 1 \mathrm{H}), 4.20(\mathrm{~m}, 1 \mathrm{H}), 4.25$ $(\mathrm{m}, 1 \mathrm{H}), 7.08-7.11(\mathrm{~m}, 5 \mathrm{H}) ;{ }^{13} \mathrm{C} \mathrm{NMR}\left(\mathrm{C}_{6} \mathrm{D}_{6}, 125 \mathrm{MHz}\right)$ $\delta$ (ppm): 17.2, 17.8, 27.5, 27.6, 39.0, 40.0, 73.1, 75.1, 77.3, 81.6, 111.5, 128.0, 128.5, 139.3, 149.0. Minor isomer: $16.0,17.4,26.0,28.9,35.7,40.2,74.0,75.0,76.4$, 108.0, 110.8 .

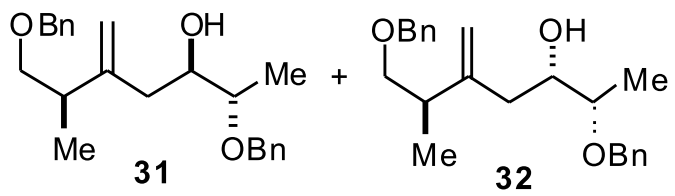

$(2 S, 3 R, 6 R)-2,7$ - bis (benzyloxy) - 6 - methyl5-methyleneheptan-3-ol (31) and $(2 S, 3 S, 6 R)-2,7-$ bis(benzyloxy)-6-methyl-5-methyleneheptan-3-ol (32): Yield: 70\%; $R f=0.36$ (EtOAc/hexanes 20\%); IR (film) v $\left(\mathrm{cm}^{-1}\right)$ : 3454, 3061, 3026, 2970, 2872, 1643, 1498, 1454, 1367, 1264, 1090; ${ }^{1} \mathrm{H} \mathrm{NMR}\left(\mathrm{CDCl}_{3}, 250 \mathrm{MHz}\right) \delta$ (ppm): $1.04(\mathrm{~d}, J=7.0 \mathrm{~Hz}, 3 \mathrm{H}), 1.22$ (d, $J=6.3 \mathrm{~Hz}, 3 \mathrm{H}), 2.09$ 2.53 (m, 3H), 3.33- 3.54 (m, 3H), 3.80-3.88 (m, 1H), 4.50 $(\mathrm{s}, 2 \mathrm{H}), 4.52(\mathrm{~d}, J=12.0 \mathrm{~Hz}, 1 \mathrm{H}), 4.63(\mathrm{~d}, J=12.0 \mathrm{~Hz}$, 1H), 4.93 (s, 1H), 4.97 (s, 1H), 7.29-7.35 (m, 10H). Minor isomer: $1.09(\mathrm{~d}, J=7.0 \mathrm{~Hz}, 3 \mathrm{H}), 1.17(\mathrm{~d}, J=6.0 \mathrm{~Hz}, 3 \mathrm{H})$, 3.62-3.72 (m, 1H), 4.00-4.10 (m, 1H); ${ }^{13} \mathrm{C} \mathrm{NMR}\left(\mathrm{CDCl}_{3}\right.$, $63 \mathrm{MHz}) \delta(\mathrm{ppm}): 14.8,17.5,39.0,70.9,73.0,74.5,112.0$, 127.5, 127.7, 128.3 138.1, 149.0. Minor isomer: 15.5, 17.2, $71.0,71.7,74.9,138.7$.

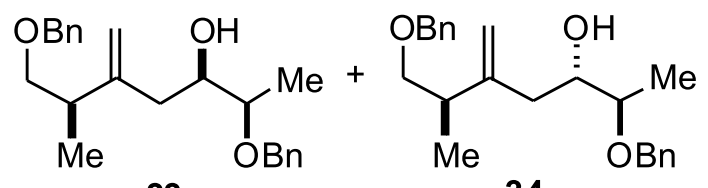
33 34

$(2 R, 3 R, 6 R)-2,7$-bis (benzyloxy) - 6-methyl-5methyleneheptan-3-ol $(33)$ and $(2 R, 3 S, 6 R)-2,7-$ bis(benzyloxy)-6-methyl-5-methyleneheptan-3-ol (34): Yield: 60\%; $R f=0.18$ (EtOAc/hexanes 10\%); IR (film) v $\left(\mathrm{cm}^{-1}\right): 3695,3055,2976,2930,1715,1452,1072,897 ;{ }^{1} \mathrm{H}$ NMR $\left(\mathrm{CDCl}_{3}, 250 \mathrm{MHz}\right) \delta(\mathrm{ppm}): 1.06(\mathrm{~d}, J=7.0 \mathrm{~Hz}, 3 \mathrm{H})$, $1.21(\mathrm{~d}, J=6.0 \mathrm{~Hz}, 3 \mathrm{H}), 2.08-2.71(\mathrm{~m}, 3 \mathrm{H}), 3.31-3.55(\mathrm{~m}$, $3 \mathrm{H}), 3.65-3.76(\mathrm{~m}, 1 \mathrm{H}), 4.48(\mathrm{~d}, J=9.2 \mathrm{~Hz}, 1 \mathrm{H}), 4.51$ (s, 2H), 4.66 (d, J = 11.3 Hz, 1H), 4.92 (s, 1H), 4.94 (s, 1H), 7.10-7.37 (m, 10H). Minor isomer: $1.20(\mathrm{~d}, J=6.3 \mathrm{~Hz}, 3 \mathrm{H})$, 3.79-3.87 (m, 1H), 4.00-4.10 (m, 1H); ${ }^{13} \mathrm{C} \mathrm{NMR}\left(\mathrm{CDCl}_{3}\right.$, $63 \mathrm{MHz}) \delta$ (ppm): 15.5, 17.4, 38.8, 39.1, 39.5, 71.1, 72.6, 
74.5, 111.8, 127.7, 128.3, 138.3, 148.9. Minor isomer: 14.5, $17.2,38.7,70.8,72.0,74.8,112.0,126.0$.

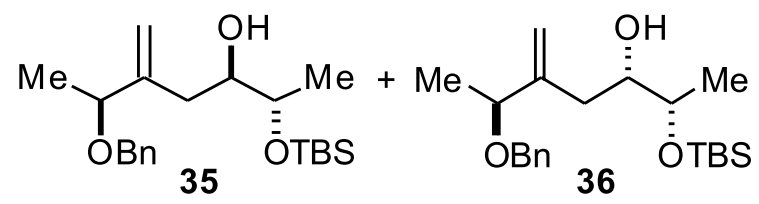

$(2 S, 3 R, 6 S)-6$ - ( b e n z y l o x y ) - 2 - ( t e r t butyldimethylsilyloxy)-5-methyleneheptan-3-ol (35) and (2S,3S,6S)-6-(benzyloxy)-2-(tert-butyldimethylsilyloxy)5-methyleneheptan-3-ol (36): Yield: $35 \% ; R f=0.17$ (EtOAc/hexanes 5\%); IR (film) $\vee\left(\mathrm{cm}^{-1}\right)$ : 3564, 3445, 3052, 2955, 2931, 2858, 1651, 1454, 1372, 1092; ${ }^{1} \mathrm{H}$ NMR $\left(\mathrm{CDCl}_{3}, 500 \mathrm{MHz}\right) \delta(\mathrm{ppm}): 0.08$ (s, 3H); 0.09 (s, 3H); 0.90 $(\mathrm{s}, 9 \mathrm{H}) ; 1.16(\mathrm{~d}, J=6.2 \mathrm{~Hz}, 3 \mathrm{H}) ; 1.31(\mathrm{~d}, J=6.6 \mathrm{~Hz}, 3 \mathrm{H})$; $2.03-2.34(\mathrm{~m}, 2 \mathrm{H}) ; 3.55(\mathrm{dq}, J=3.3,1.5 \mathrm{~Hz}, 1 \mathrm{H}) ; 3.71-3.81$ $(\mathrm{m}, 1 \mathrm{H}) ; 3.95-4.03(\mathrm{~m}, 1 \mathrm{H}) ; 4.36(\mathrm{~d}, J=11.7 \mathrm{~Hz}, 1 \mathrm{H}) ; 4.56$ (d, $J=11.7 \mathrm{~Hz}, 1 \mathrm{H}) ; 5.07$ (s, 1H); $5.12(\mathrm{~s}, 1 \mathrm{H}) ; 7.27-7.33$ $(\mathrm{m}, 5 \mathrm{H})$. Minor isomer: 0.07 (s, 3H); $0.08(\mathrm{~s}, 3 \mathrm{H}) ; 0.89$ (s, $9 \mathrm{H}) ; 1.13(\mathrm{~d}, J=5.9 \mathrm{~Hz}, 3 \mathrm{H}) ; 1.32(\mathrm{~d}, J=6.2 \mathrm{~Hz}, 3 \mathrm{H})$; ); $4.36(\mathrm{~d}, J=11.7 \mathrm{~Hz}, 1 \mathrm{H}) ; 4.53(\mathrm{~d}, J=11.7 \mathrm{~Hz}, 1 \mathrm{H}) ; 5.10$ (s, $1 \mathrm{H}) ; 5.14$ (s, $1 \mathrm{H}) .{ }^{13} \mathrm{C}$ NMR $\left(\mathrm{C}_{6} \mathrm{D}_{6}, 75 \mathrm{MHz}\right) \delta(\mathrm{ppm})$ : -4.7, -4.2, 18.2, 19.2, 20.5, 26.0, 34.7, 70.2, 71.6, 74.9, 78.9, 113.7, 114.1, 127.8, 128.5, 139.2, 148.0. Minor isomer: $-4.6,-4.3,18.5,21.2,72.1,74.6,79.1$.

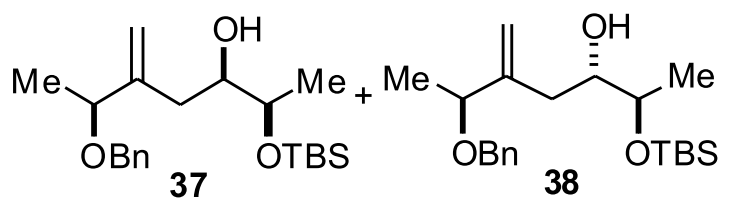

$(2 R, 3 R, 6 S)-6$ - ( b e n z y lox y ) - 2 - ( tert butyldimethylsilyloxy)-5-methyleneheptan-3-ol (37) and (2R,3S,6S)-6-(benzyloxy)-2-(tert-butyldimethylsilyloxy)5-methyleneheptan-3-ol (38): Yield: $47 \% ; R f=0.25$ (EtOAc/hexanes 10\%); IR (film) $v\left(\mathrm{~cm}^{-1}\right)$ : 3564, 3435, 3052, 2960, 2931, 2862, 1647, 1454, 1371, 1090; ${ }^{1} \mathrm{H}$ NMR $\left(\mathrm{CDCl}_{3}, 250 \mathrm{MHz}\right) \delta(\mathrm{ppm}): 0.09$ (s, 6H), $0.90(\mathrm{~s}, 9 \mathrm{H})$, $1.16(\mathrm{~d}, J=6.3 \mathrm{~Hz}, 3 \mathrm{H}), 1.31(\mathrm{~d}, J=6.6 \mathrm{~Hz}, 3 \mathrm{H}), 2.03-$ $2.49(\mathrm{~m}, 2 \mathrm{H}), 3.57(\mathrm{dq}, J=4.1,1.3 \mathrm{~Hz}, 1 \mathrm{H}), 3.65-3.76(\mathrm{~m}$, $1 \mathrm{H}), 3.92-4.05(\mathrm{~m}, 1 \mathrm{H}), 4.36(\mathrm{~d}, J=11.7 \mathrm{~Hz}, 1 \mathrm{H}), 4.52$ (d, $J=11.7 \mathrm{~Hz}, 1 \mathrm{H}), 5.10(\mathrm{~d}, J=1.6 \mathrm{~Hz}, 1 \mathrm{H}), 5.14$ (s, $1 \mathrm{H}), 7.26-7.35(\mathrm{~m}, 5 \mathrm{H})$. Minor isomer: $0.08(\mathrm{~s}, 3 \mathrm{H}), 0.89$ (s, 9H), 1.15 (d, $J=6.3 \mathrm{~Hz}, 3 \mathrm{H}), 1.32(\mathrm{~d}, J=6.6 \mathrm{~Hz}, 3 \mathrm{H})$, $4.36(\mathrm{~d}, J=11.7 \mathrm{~Hz}, 1 \mathrm{H}), 4.53(\mathrm{~d}, J=11.7 \mathrm{~Hz}, 1 \mathrm{H}), 5.07$ $(\mathrm{d}, J=1.6 \mathrm{~Hz}, 1 \mathrm{H}) ;{ }^{13} \mathrm{C}\left(\mathrm{CDCl}_{3}, 63 \mathrm{MHz}\right) \delta(\mathrm{ppm}):-4.8$, $-4.2,18.0,20.0,20.1,25.8,35.3,70.0,71.5,74.3,78.4$, 113.2, 127.7, 128.4, 138.7, 147.2; Minor isomer: 18.6, 20.3, 34.3, 74.6, 114.1.<smiles>C=C(CC(O)C(C)O)C(O)CC(=O)C(C)OCc1ccccc1</smiles>

(2S,6S)-6-(benzyloxy)-5-methyleneheptane-2,3-diol (39) and (40): Yield: 67\%; $R f=0.36$ (EtOAc/hexanes 50\%); ${ }^{1} \mathrm{H} \mathrm{NMR}\left(\mathrm{CDCl}_{3}, 300 \mathrm{MHz}\right) \delta(\mathrm{ppm}): 1.18(\mathrm{~d}, J=6.6 \mathrm{~Hz}$, $3 \mathrm{H}), 1.32(\mathrm{~d}, J=6.6 \mathrm{~Hz}, 3 \mathrm{H}), 2.14-2.45(\mathrm{~m}, 2 \mathrm{H}), 3.61(\mathrm{dt}$, $J=3.7,8.8 \mathrm{~Hz}, 1 \mathrm{H}), 3.70(\mathrm{br}, 2 \mathrm{H}), 3.79-3.87(\mathrm{~m}, 1 \mathrm{H})$, $4.00(\mathrm{q}, J=6.6 \mathrm{~Hz}, 1 \mathrm{H}), 4.41(\mathrm{~d}, J=11.7,1 \mathrm{H}), 4.56(\mathrm{~d}, J$ $=11.7,1 \mathrm{H}), 5.07(\mathrm{~s}, 1 \mathrm{H}), 5.10(\mathrm{~s}, 1 \mathrm{H}), 7.27-7.37(\mathrm{~m}, 5 \mathrm{H})$. Minor isomer: 1.19 (d, $J=6.0 \mathrm{~Hz}, 3 \mathrm{H}), 1.33(\mathrm{~d}, J=6.6$ $\mathrm{Hz}, 3 \mathrm{H}) ;{ }^{13} \mathrm{C}$ NMR $\left(\mathrm{CDCl}_{3}, 75 \mathrm{MHz}\right) \delta(\mathrm{ppm}): 17.4,19.9$, 33.6, 70.1, 74.6, 78.7, 115.9, 127.7, 128.5, 137.8, 146.8. Minor isomer: 19.2, 19.4, 35.6, 70.3, 78.5.<smiles>C=C(C[C@@H]1OC(C)([14CH3])OC1(C)C)C(C)OCc1ccccc1</smiles>

(4R,5S)-4-((S)-3-(benzyloxy)-2-methylenebutyl)2,2,5-trimethyl-1,3-dioxolane (41) and $(4 S, 5 S)-4-((S)$ 3-(benzyloxy)-2-methylenebutyl)-2,2,5-trimethyl-1,3dioxolane (42): Yield: $50 \% ; R f=0.55$ (EtOAc/hexanes 20\%); IR (film) $v\left(\mathrm{~cm}^{-1}\right): 3055,2986,2934,2872,1647$, $1454,1371,1086 ;{ }^{1} \mathrm{H}$ NMR $\left(\mathrm{C}_{6} \mathrm{D}_{6}, 300 \mathrm{MHz}\right) \delta(\mathrm{ppm}): 1.01$ $(\mathrm{d}, J=6.2 \mathrm{~Hz}, 3 \mathrm{H}), 1.28(\mathrm{~d}, J=6.6 \mathrm{~Hz}, 3 \mathrm{H}), 1.31(\mathrm{~s}, 3 \mathrm{H})$, $1.48(\mathrm{~s}, 3 \mathrm{H}), 2.10-2.33(\mathrm{~m}, 2 \mathrm{H}), 3.55-3.93(\mathrm{~m}, 1 \mathrm{H}), 3.91$ (q, $J=6.6 \mathrm{~Hz}, 1 \mathrm{H}$ ), 4.06 (apquint, $J=6.2 \mathrm{~Hz}, 1 \mathrm{H}$ ), 4.30 $(\mathrm{d}, J=12.0 \mathrm{~Hz}, 1 \mathrm{H}), 4.53(\mathrm{~d}, J=12.0 \mathrm{~Hz}, 1 \mathrm{H}), 5.10$ (s, $1 \mathrm{H}), 5.14(\mathrm{~s}, 1 \mathrm{H}), 7.07-7.37(\mathrm{~m}, 5 \mathrm{H})$. Minor isomer: 1.08 $(\mathrm{d}, J=5.9 \mathrm{~Hz}, 3 \mathrm{H}), 1.39$ (s, 3H), 1.41 (s, 3H), 3.75 (ddd, $J=3.3,8.4 \mathrm{~Hz}, 1 \mathrm{H}), 4.21-4.40(\mathrm{~m}, 2 \mathrm{H}) ;{ }^{13} \mathrm{C}$ NMR $\left(\mathrm{C}_{6} \mathrm{D}_{6}\right.$, $75 \mathrm{MHz}) \delta$ (ppm): 15.9, 20.6, 27.5, 27.6, 31.4, 70.1, 74.0, 76.9, 77.2, 81.1, 107.4, 112.9, 139.6, 147.1. Minor isomer: 17.6, 26.0, 28.9, 33.4, 78.9, 78.6, 108.0, 113.2.<smiles>[M]C(O)C(O)CC(=C)C(C)O</smiles><smiles>C=C(C[C@@H](O)C(C)O)C(C)O</smiles>

(2R,6S)-6-(benzyloxy)-5-methyleneheptane-2,3-diol (43) and (44): Yield: 90\%; $R f=0.40$ (EtOAc/hexanes 50\%); IR (film) $\vee\left(\mathrm{cm}^{-1}\right): 3416,3069,2976,2930,2867$, 1722, 1647, 1454, 1371, 1275, 1070; ${ }^{1} \mathrm{H} \mathrm{NMR}\left(\mathrm{CDCl}_{3}\right.$, 
$300 \mathrm{MHz}) \delta(\mathrm{ppm}): 1.19(\mathrm{~d}, J=6.6 \mathrm{~Hz}, 3 \mathrm{H}), 1.34(\mathrm{~d}, J=$ $6.6 \mathrm{~Hz}, 3 \mathrm{H}), 2.14-2.27(\mathrm{~m}, 2 \mathrm{H}), 2.40(\mathrm{~d}, J=3.3 \mathrm{~Hz}, \mathrm{OH})$, 3.49-3.55 (m, 1H), 3.61 (apqt, $J=6.2 \mathrm{~Hz}, 1 \mathrm{H}), 4.01(\mathrm{q}, J$ $=6.6 \mathrm{~Hz}, 1 \mathrm{H}), 4.44(\mathrm{~d}, J=12.0 \mathrm{~Hz}, 1 \mathrm{H}), 4.52(\mathrm{~d}, J=12.0$ $\mathrm{Hz}, 1 \mathrm{H}), 5.05(\mathrm{~s}, 1 \mathrm{H}), 5.14(\mathrm{~s}, 1 \mathrm{H}), 7.26-7.37(\mathrm{~m}, 5 \mathrm{H})$. Minor isomer: $1.18(\mathrm{~d}, J=6.6 \mathrm{~Hz}, 3 \mathrm{H}), 1.32(\mathrm{~d}, J=6.6$ $\mathrm{Hz}, 3 \mathrm{H}), 2.44$ (d, $J=3.3 \mathrm{~Hz}, \mathrm{OH}), 3.80-3.88(\mathrm{~m}, 1 \mathrm{H}), 5.11$ (s, $1 \mathrm{H}) ;{ }^{13} \mathrm{C} \mathrm{NMR}\left(\mathrm{CDCl}_{3}, 75 \mathrm{MHz}\right) \delta(\mathrm{ppm}): 19.3,19.5$, 35.7, 70.3, 74.3, 78.5, 115.4, 127.7, 128.4, 137.8, 145.9. Minor isomer: 17.5, 20.0, 74.6, 78.7 .

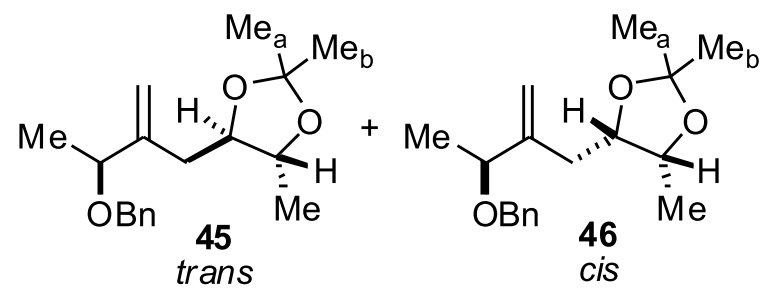

(4R,5R)-4-((S)-3-(benzyloxy)-2-methylenebutyl)2,2,5-trimethyl-1,3-dioxolane (45) and $(4 S, 5 R)-4-((S)$ 3-(benzyloxy)-2-methylenebutyl)-2,2,5-trimethyl-1,3dioxolane (46): Yield: 90\%; $R f=0.27$ (EtOAc/hexanes $5 \%$ ); IR (film) $\vee\left(\mathrm{cm}^{-1}\right): 3053,2963,2936,2874,1724$, $1649,1454,1379,1265,1089,912,842 ;{ }^{1} \mathrm{H} N M R\left(\mathrm{CDCl}_{3}\right.$, $300 \mathrm{MHz}) \delta(\mathrm{ppm}): 1.26(\mathrm{~d}, J=6.0 \mathrm{~Hz}, 3 \mathrm{H}), 1.31(\mathrm{~d}, J=$ $6.6 \mathrm{~Hz}, 3 \mathrm{H}), 1.39$ (s, 6H), 2.13-2.38 (m, 2H), 3.68-3.79 $(\mathrm{m}, 1 \mathrm{H}), 3.95-4.09(\mathrm{~m}, 1 \mathrm{H}), 4.31-4.41(\mathrm{~m}, 1 \mathrm{H}), 4.33(\mathrm{~d}$, $J=12.0 \mathrm{~Hz}, 1 \mathrm{H}), 4.50(\mathrm{~d}, J=12.0 \mathrm{~Hz}, 1 \mathrm{H}), 5.15(\mathrm{~s}, 2 \mathrm{H})$, 7.23-7.36 (m, 5H); Minor isomer: $0.99(\mathrm{~d}, J=6.6 \mathrm{~Hz}, 3 \mathrm{H})$, 1.17 (d, $J=6.2 \mathrm{~Hz}, 3 \mathrm{H}), 1.35$ (s, 3H), 1.46 (s, 3H), 5.06 (s, $2 \mathrm{H}) ;{ }^{13} \mathrm{C} \mathrm{NMR}\left(\mathrm{CDCl}_{3}, 75 \mathrm{MHz}\right) \delta(\mathrm{ppm}): 17.9,20.5$, 27.6, 33.5, 70.2, 78.7, 81.2, 108.1, 113.7, 127.8, 128.5, 138.8, 146.6. Minor isomer: 16.1, 19.5, 26.1, 28.9, 30.8, 72.0, 74.0, 76.2, 112.9, 115.1.

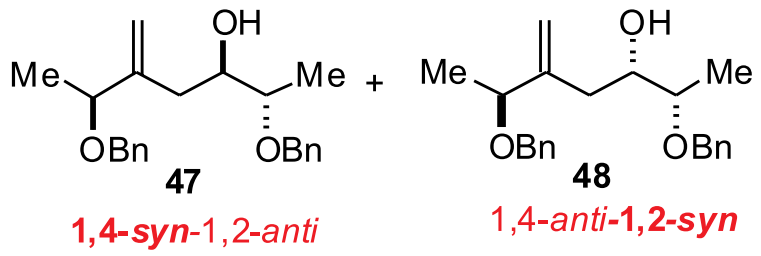

(2S,3R,6S)-2,6-bis(benzyloxy)-5-methyleneheptan3-ol (47) and $(2 S, 3 S, 6 S)$-2,6-bis(benzyloxy)-5methyleneheptan-3-ol (48): Yield: $70 \% ; R f=0.55$ (EtOAc/hexanes 20\%); IR (film) $v\left(\mathrm{~cm}^{-1}\right): 3695,3055$, 2986, 2930, 2685, 1715, 1603, 1452, 1265, 1072, 744; ${ }^{1} \mathrm{H}$ NMR $\left(\mathrm{CDCl}_{3}, 250 \mathrm{MHz}\right) \delta(\mathrm{ppm}): 1.20(\mathrm{~d}, J=6.3 \mathrm{~Hz}, 3 \mathrm{H})$, $1.32(\mathrm{~d}, J=6.6 \mathrm{~Hz}, 3 \mathrm{H}), 2.12-2.46(\mathrm{~m}, 2 \mathrm{H}), 3.51$ (ddd, $J$ $=4.3,6.3,12.6 \mathrm{~Hz}, 1 \mathrm{H}), 3.87-4.13(\mathrm{~m}, 2 \mathrm{H}), 4.37(\mathrm{~d}, J=$ $12.0,1 \mathrm{H}), 4.49(\mathrm{~d}, J=11.7 \mathrm{~Hz}, 1 \mathrm{H}), 4.51(\mathrm{~d}, J=11.7 \mathrm{~Hz}$, $1 \mathrm{H}), 4.61(\mathrm{~d}, J=11.7 \mathrm{~Hz}, 1 \mathrm{H}), 5.08(\mathrm{~s}, 1 \mathrm{H}), 5.14(\mathrm{~s}, 1 \mathrm{H})$, 7.26-7.37 (m, 10H). Minor isomer: $1.22(\mathrm{~d}, J=6.3 \mathrm{~Hz}, 1 \mathrm{H})$; ${ }^{13} \mathrm{C} \mathrm{NMR}\left(\mathrm{CDCl}_{3}, 63 \mathrm{MHz}\right) \delta(\mathrm{ppm}): 14.1,19.9,34.1,70.7$, 72.0, 77.5, 78.5, 114.0, 127.6, 128.4, 138.6, 146.7.Minor isomer: $15.2,20.3,34.5,70.0,71.0,73.3,78.4,79.4,114.2$, $127.5,126.9,138.5,146.9$.<smiles>C=C(CC(O)[C@@H](C)OCc1ccccc1)C(C)OCc1ccccc1</smiles>

1,4-syn-1,2-syn<smiles>C=C(C[C@@H](O)[C@@H](C)OCc1ccccc1)C(C)OCc1ccccc1</smiles>

1,4-anti-1,2-anti
$(2 R, 3 R, 6 S)$-2,6-bis(benzyloxy)-5-methyleneheptan3-ol (49) and $(2 R, 3 S, 6 S)-2,6$-bis(benzyloxy)-5methyleneheptan-3-ol (50): Yield: $88 \% ; R f=0.55$ (EtOAc/ hexanes $10 \%) ;{ }^{1} \mathrm{H} \mathrm{NMR}\left(\mathrm{CDCl}_{3}, 250 \mathrm{MHz}\right) \delta(\mathrm{ppm}): 1.22$ $(\mathrm{d}, J=6.3 \mathrm{~Hz}, 3 \mathrm{H}), 1.32(\mathrm{~d}, J=6.3 \mathrm{~Hz}, 3 \mathrm{H}), 2.11-2.42(\mathrm{~m}$, $1 \mathrm{H}), 3.42-3.54(\mathrm{~m}, 1 \mathrm{H}), 3.68-3.83(\mathrm{~m}, 1 \mathrm{H}), 3.93-4.08(\mathrm{~m}$, $1 \mathrm{H}), 4.34-4.69(\mathrm{~m}, 4 \mathrm{H}), 5.09(\mathrm{~d}, J=15 \mathrm{~Hz}, 1 \mathrm{H}), 5.14(\mathrm{~d}$, $J=5.4 \mathrm{~Hz}, 1 \mathrm{H}), 7.23-7.35(\mathrm{~m}, 10 \mathrm{H})$. Minor isomer: 1.23 $(\mathrm{d}, J=6.3 \mathrm{~Hz}, 1 \mathrm{H}) ;{ }^{13} \mathrm{C} \mathrm{NMR}\left(\mathrm{CDCl}_{3}, 63 \mathrm{MHz}\right) \delta(\mathrm{ppm})$ : 15.6, 20.2, 34.9, 70.0, 71.1, 73.4, 77.8, 78.4, 113.5, 127.7, 127.8, 128.3, 128.4, 138.6, 146.9. Minor isomer: 14.7, 34.7, 70.9, 73.0, 114.6, 127.4, 127.5, 138.3 . 
Vol. 00, No. 00, 2009

Dias et al.

S7

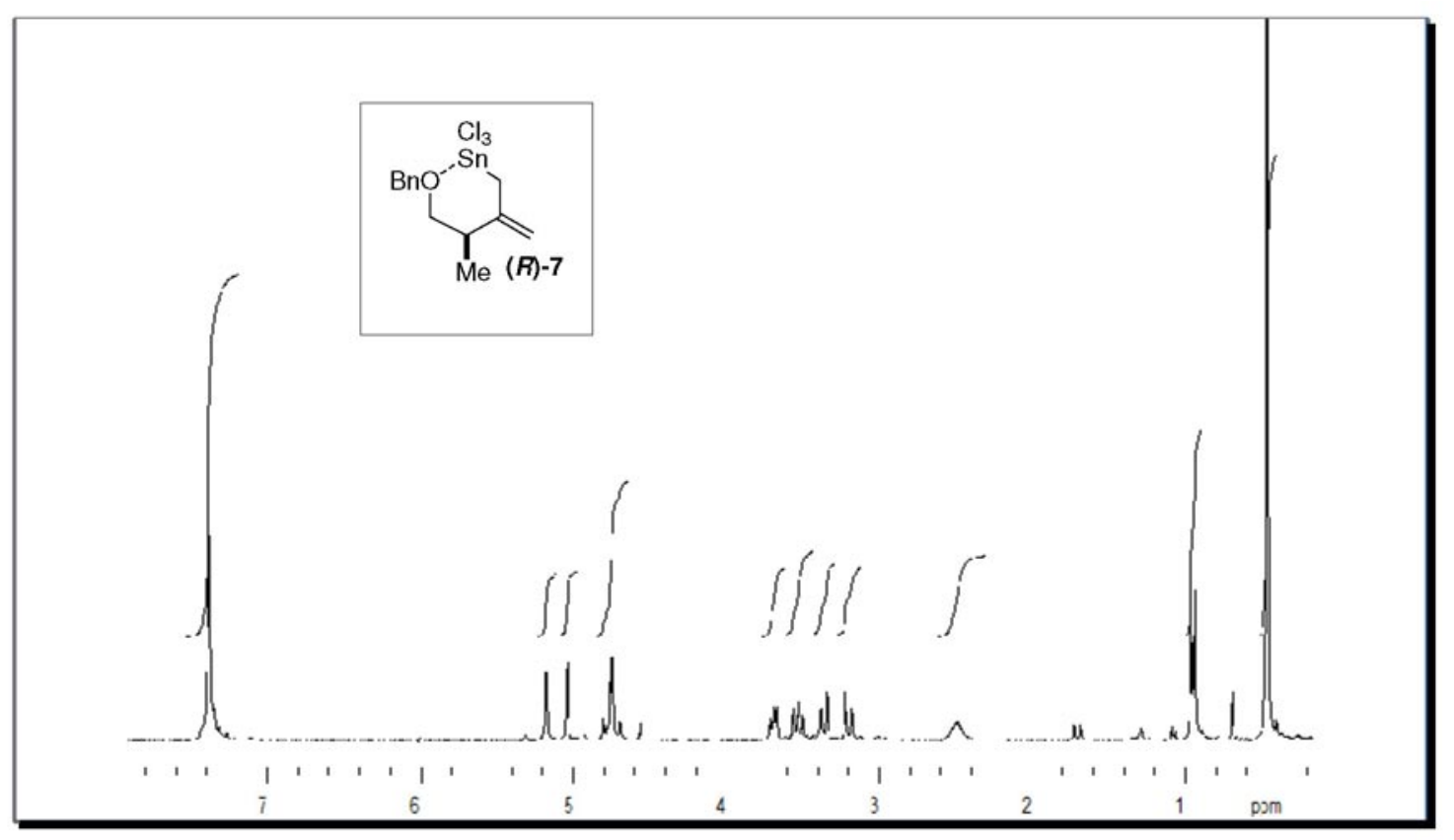

Figure 1S. ${ }^{1} \mathrm{H} \mathrm{NMR}\left(\mathrm{CDCl}_{3}, 300 \mathrm{MHz}\right)$ - (R)-(4-(benzyloxy)-3-methyl-2-methylenebutyl)trichlorostannane (7).

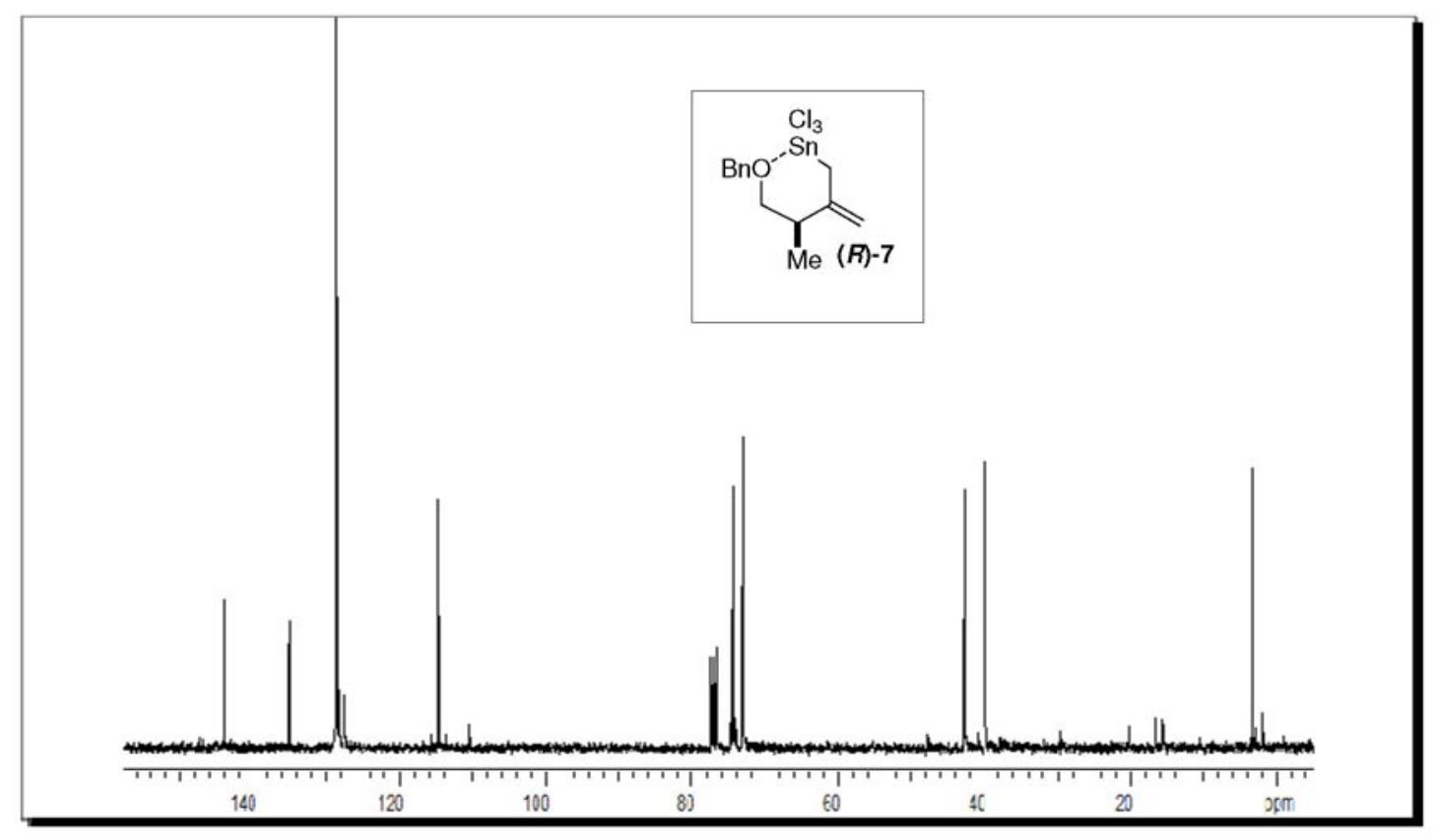

Figure 2S. ${ }^{13} \mathrm{C} \mathrm{NMR}\left(\mathrm{CDCl}_{3}, 75 \mathrm{MHz}\right)$ - (R)-(4-(benzyloxy)-3-methyl-2-methylenebutyl)trichlorostannane (7). 


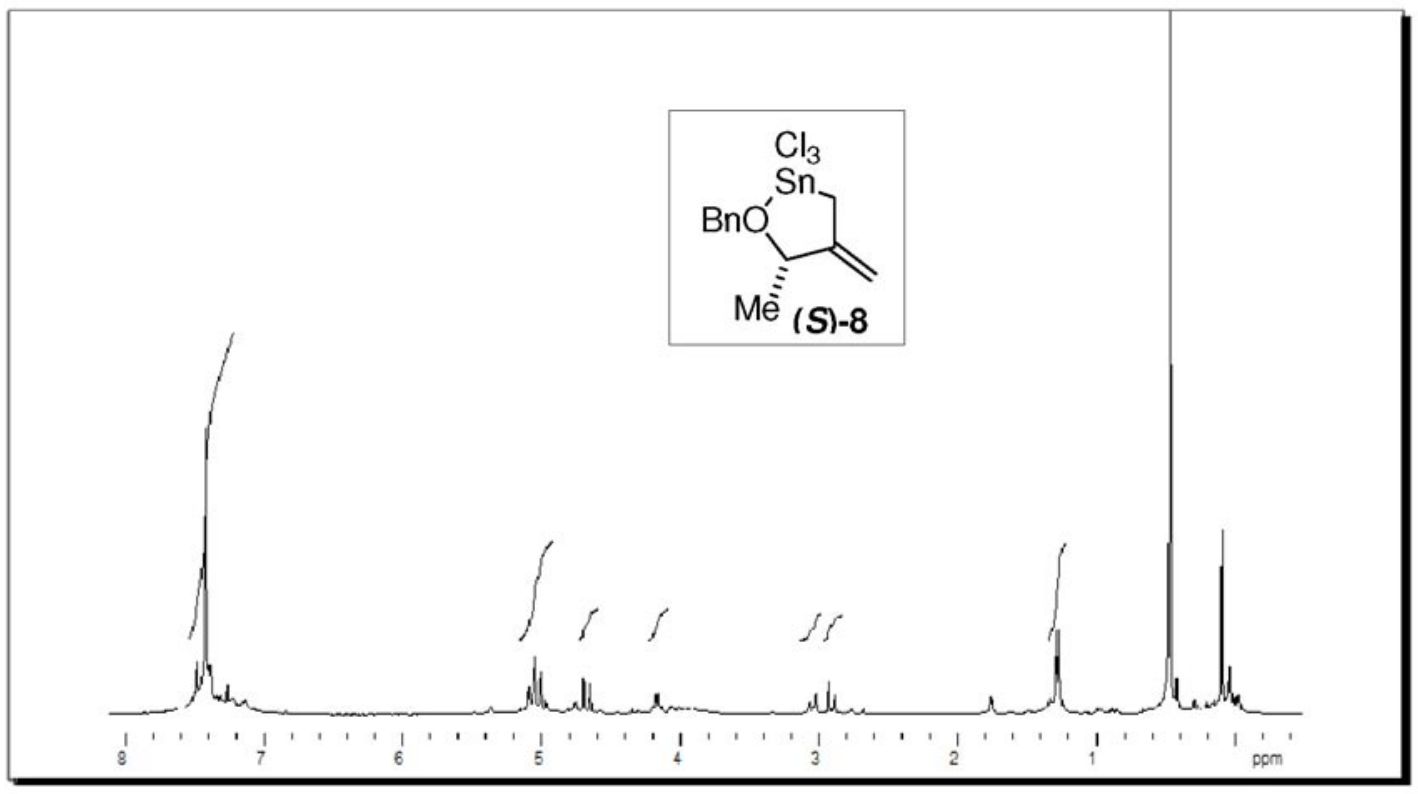

Figure 3S. ${ }^{1} \mathrm{H}$ NMR $\left(\mathrm{CDCl}_{3}, 300 \mathrm{MHz}\right)$ - (S)-(3-(benzyloxy)-2-methylenebutyl)trichlorostannane (8).

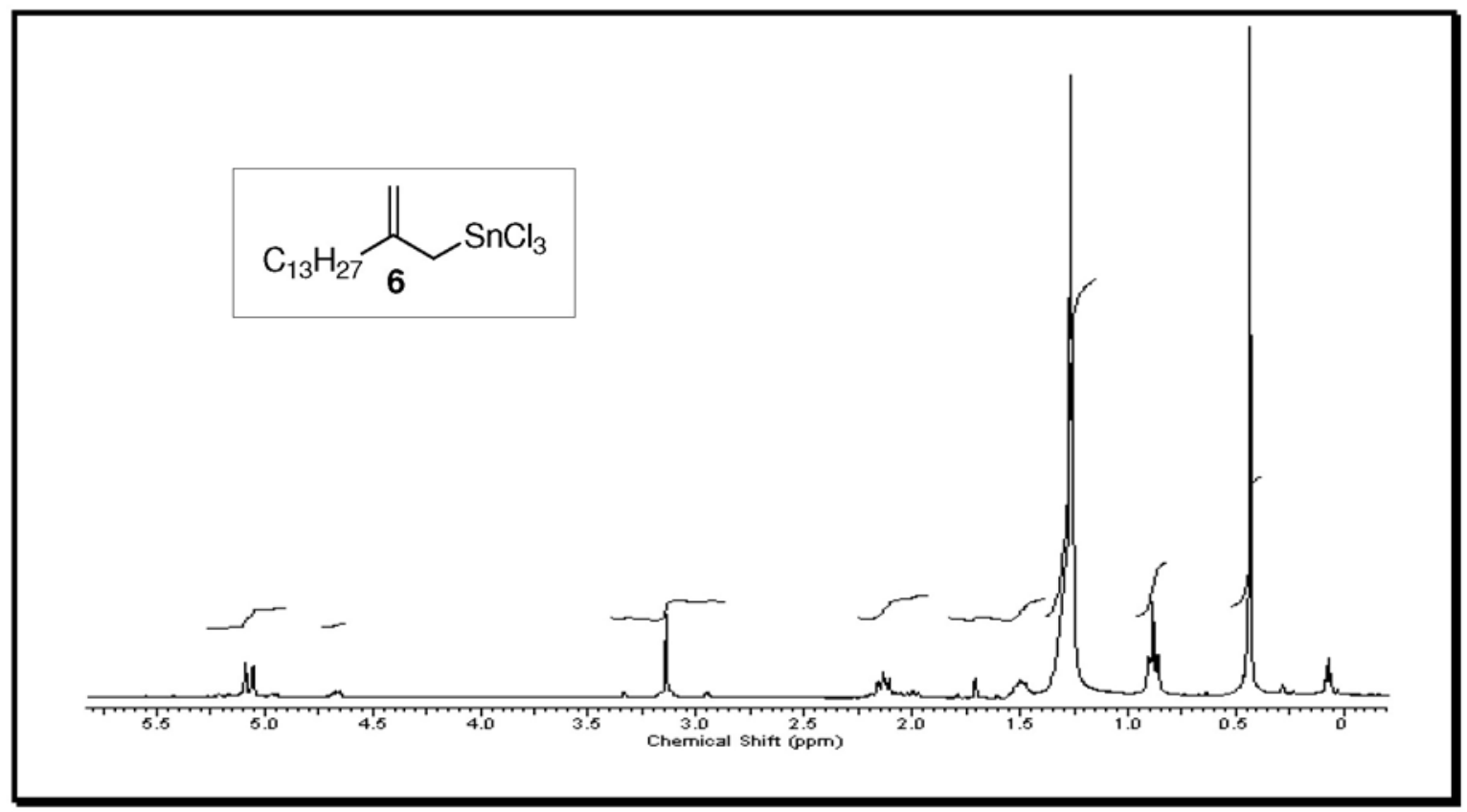

Figure 4S. ${ }^{1} \mathrm{H} \mathrm{NMR}\left(\mathrm{CDCl}_{3}, 300 \mathrm{MHz}\right)$ - Trichloro(2-methylenepentadecyl)stannane (6). 
Vol. 00, No. 00, 2009

Dias et al.

Sq

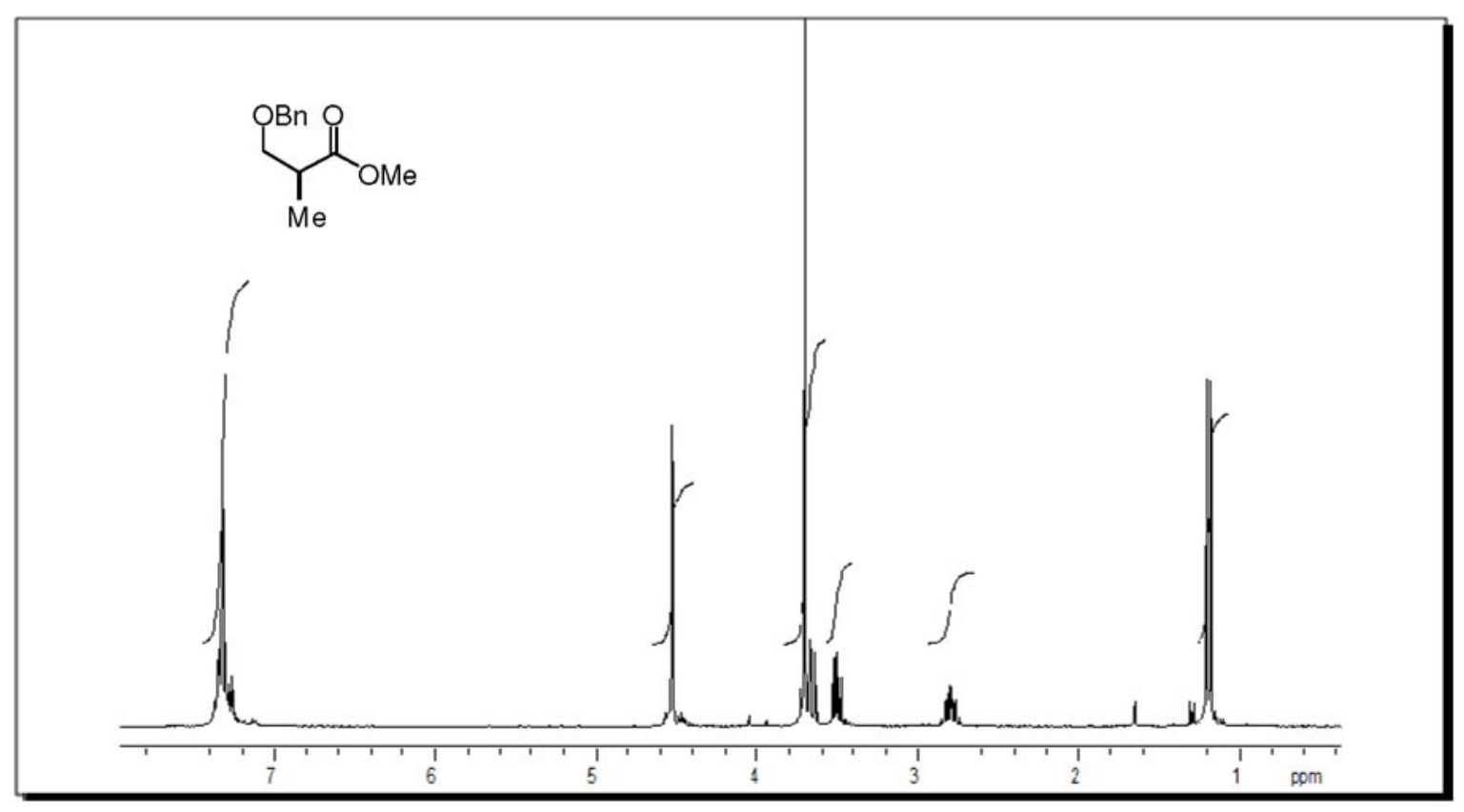

Figure 5S. ${ }^{1} \mathrm{H} \mathrm{NMR}\left(\mathrm{CDCl}_{3}, 300 \mathrm{MHz}\right)$.

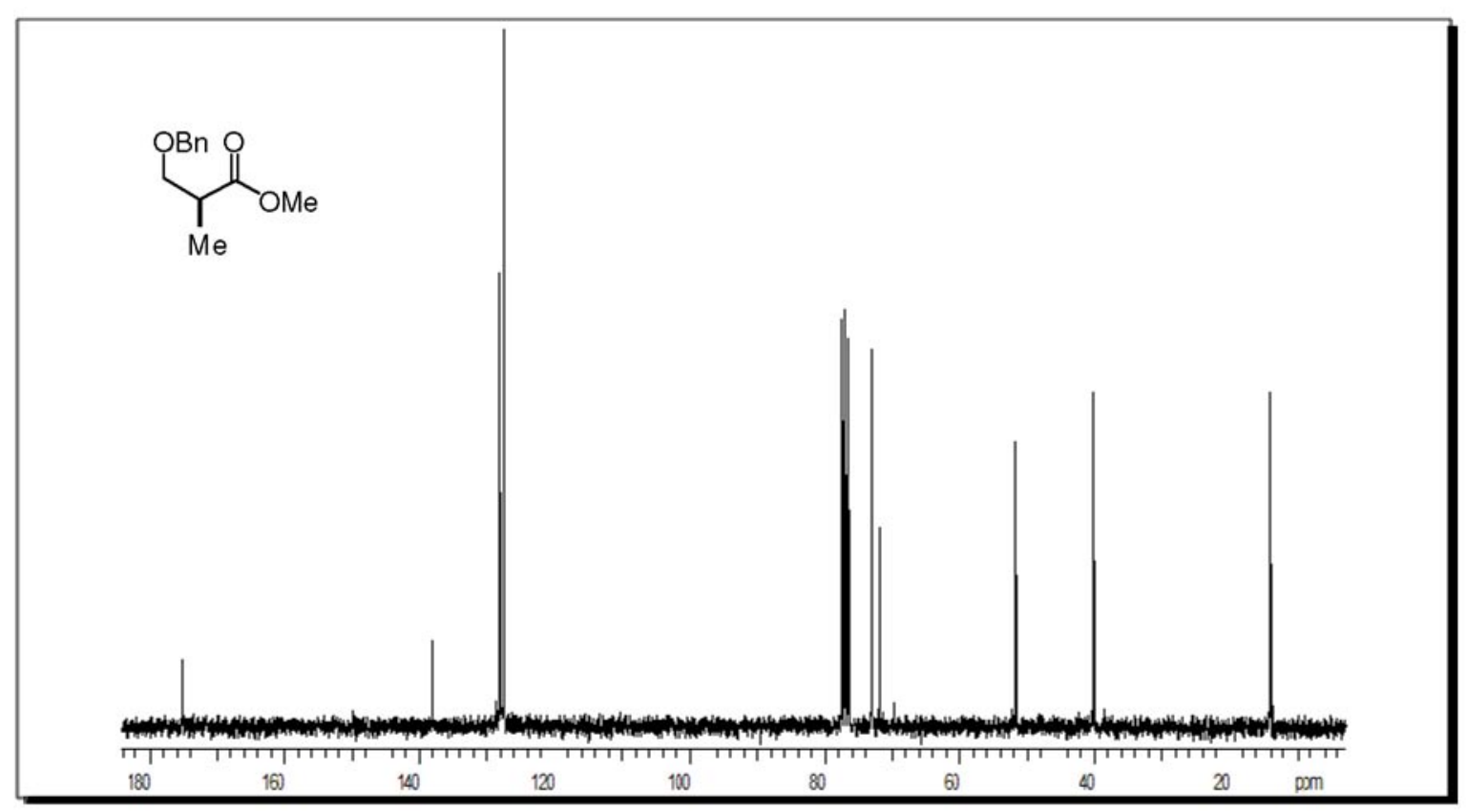

Figure 6S. ${ }^{13} \mathrm{C} \mathrm{NMR}\left(\mathrm{CDCl}_{3}, 75 \mathrm{MHz}\right)$. 


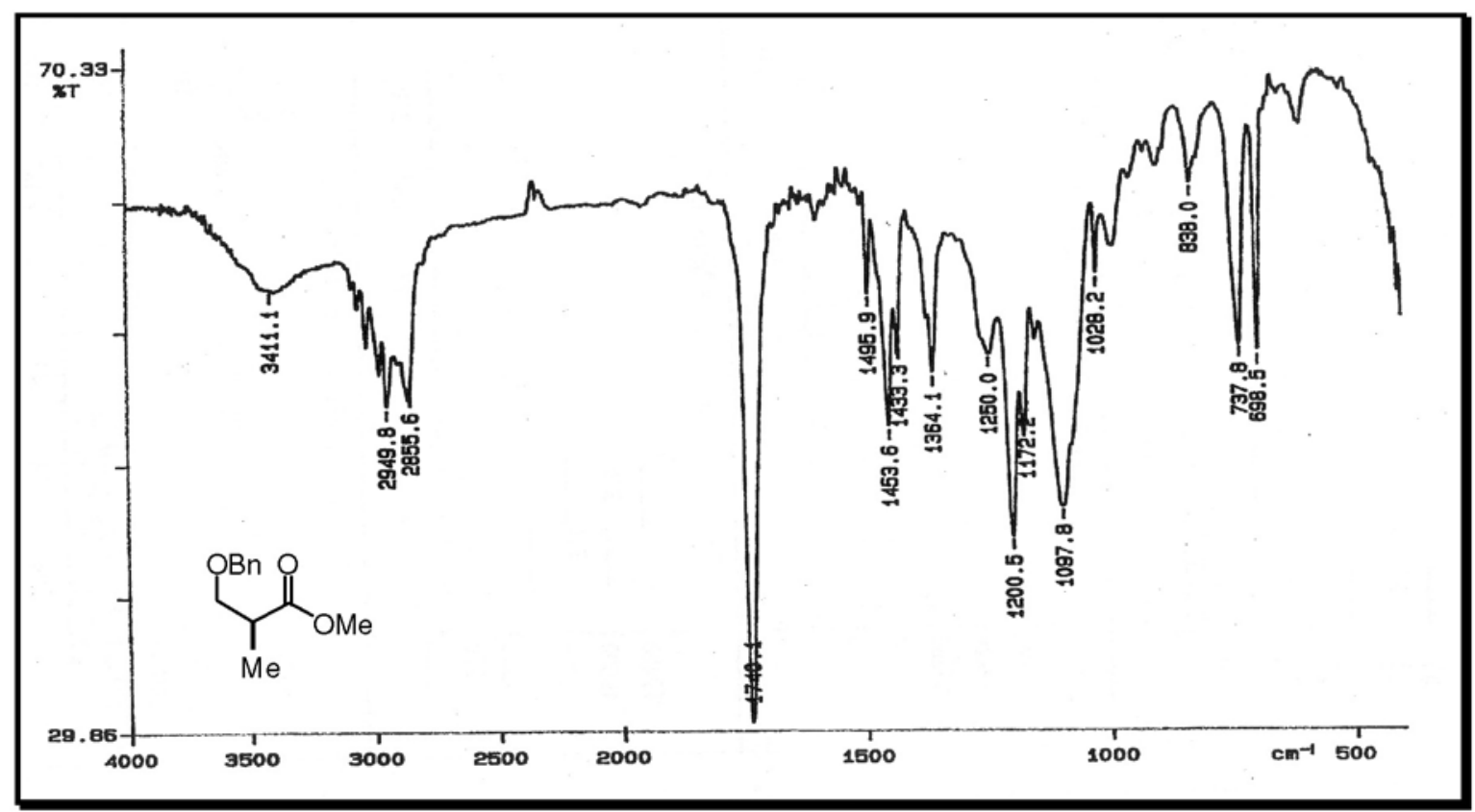

Figure 7S. IR (film).

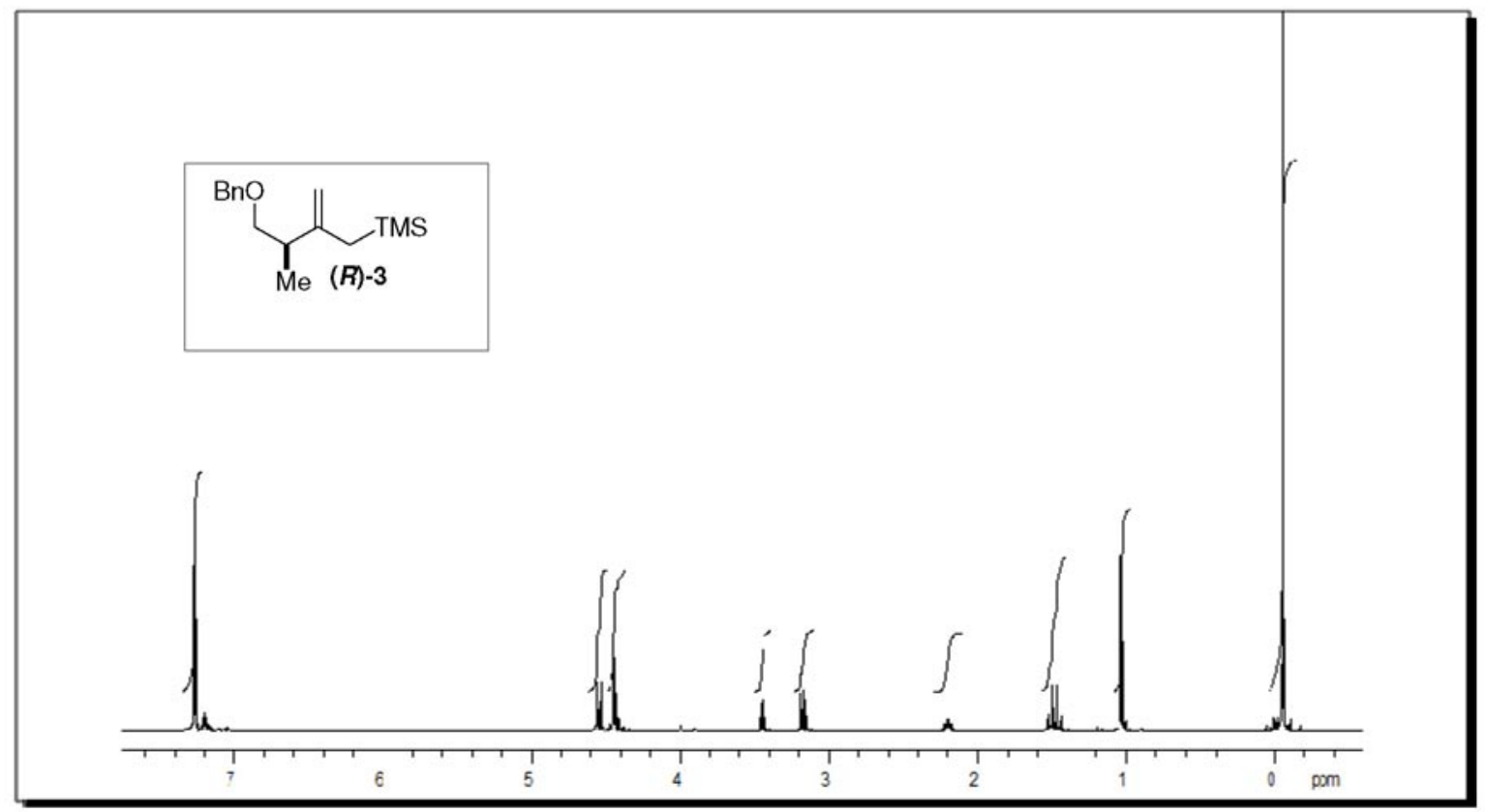

Figure 8S. ${ }^{1} \mathrm{H} \mathrm{NMR}\left(\mathrm{CDCl}_{3}, 300 \mathrm{MHz}\right)$ - (R)-(4-(benzyloxy)-3-methyl-2-methylenebutyl)trimethylsilane (3). 


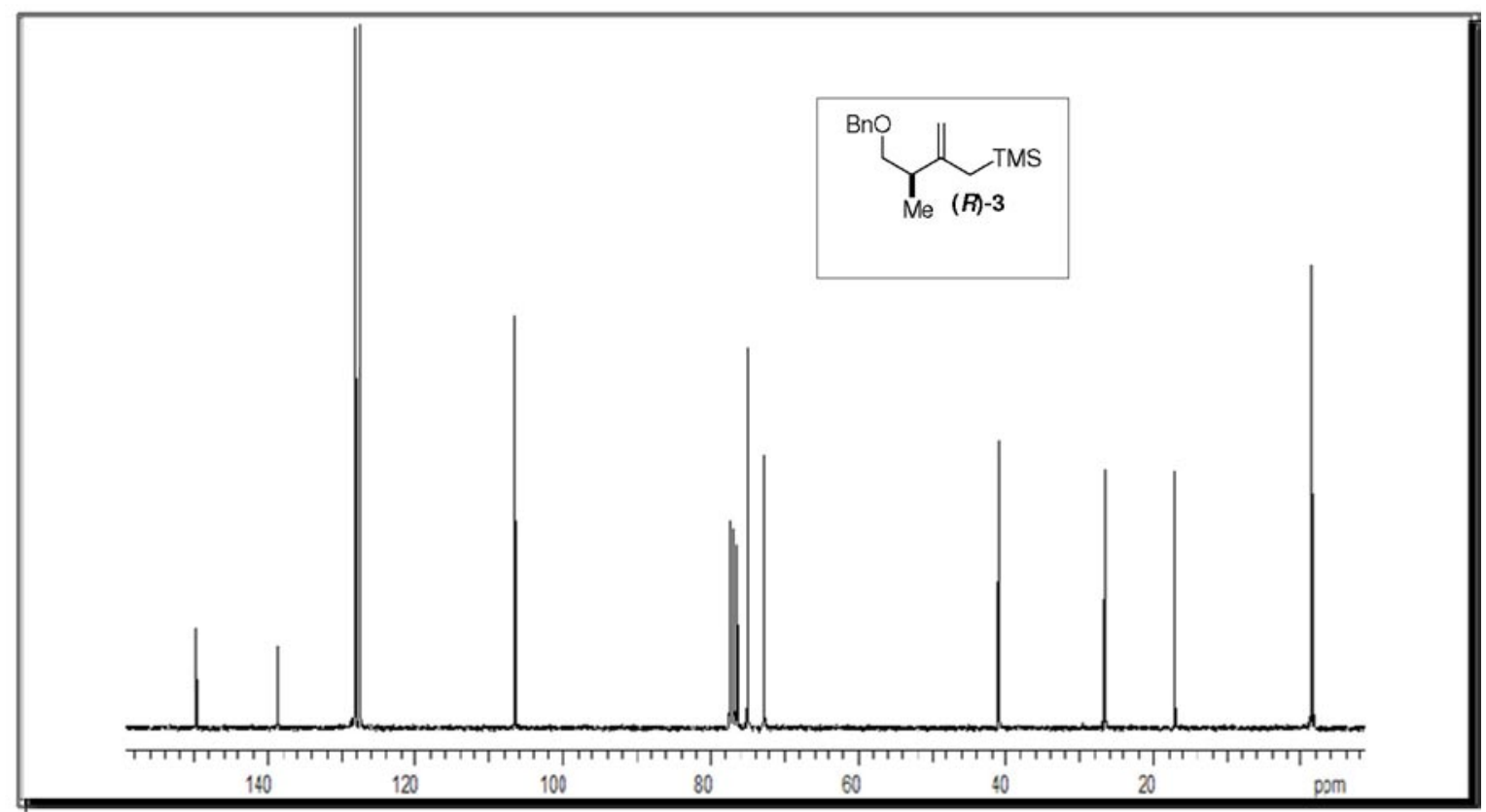

Figure 9S. ${ }^{13} \mathrm{C} \mathrm{NMR}\left(\mathrm{CDCl}_{3}, 75 \mathrm{MHz}\right)$ - (S)-(3-(benzyloxy)-2-methylenebutyl)trimethylsilane (4).

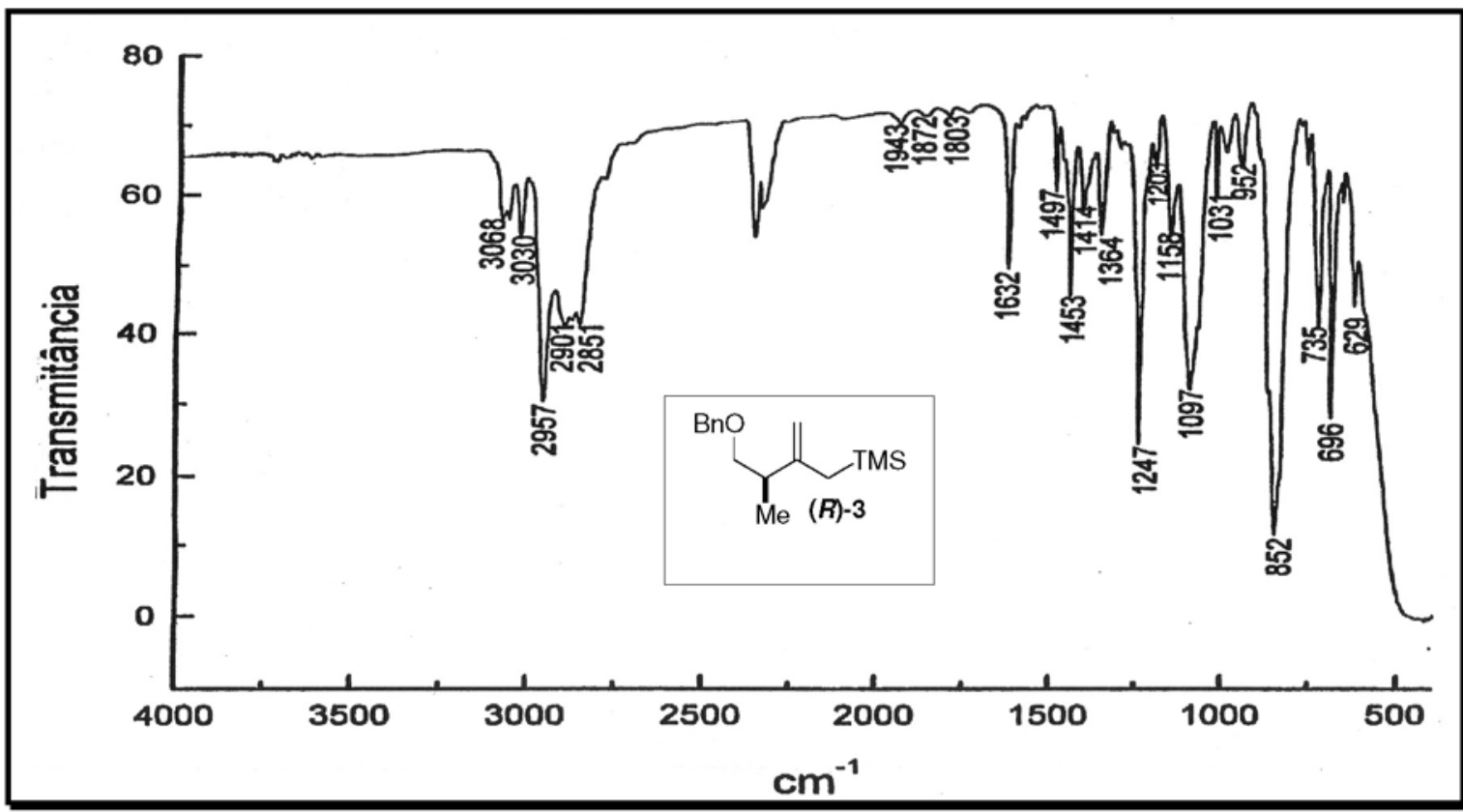

Figure 10S. IR (film) - (S)-(3-(benzyloxy)-2-methylenebutyl)trimethylsilane (4). 


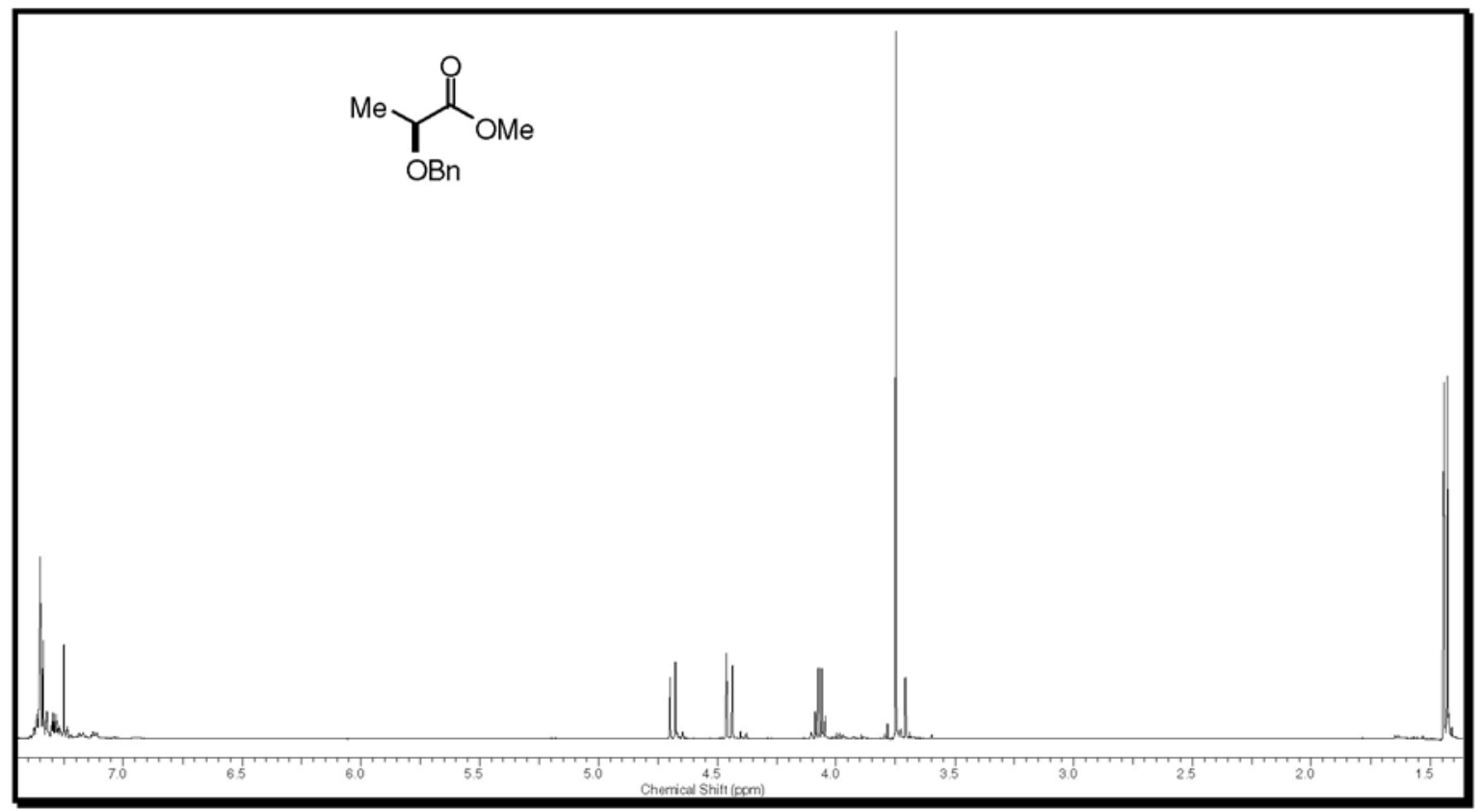

Figure 11S. ${ }^{1} \mathrm{H} \mathrm{NMR}\left(\mathrm{CDCl}_{3}, 300 \mathrm{MHz}\right)$.

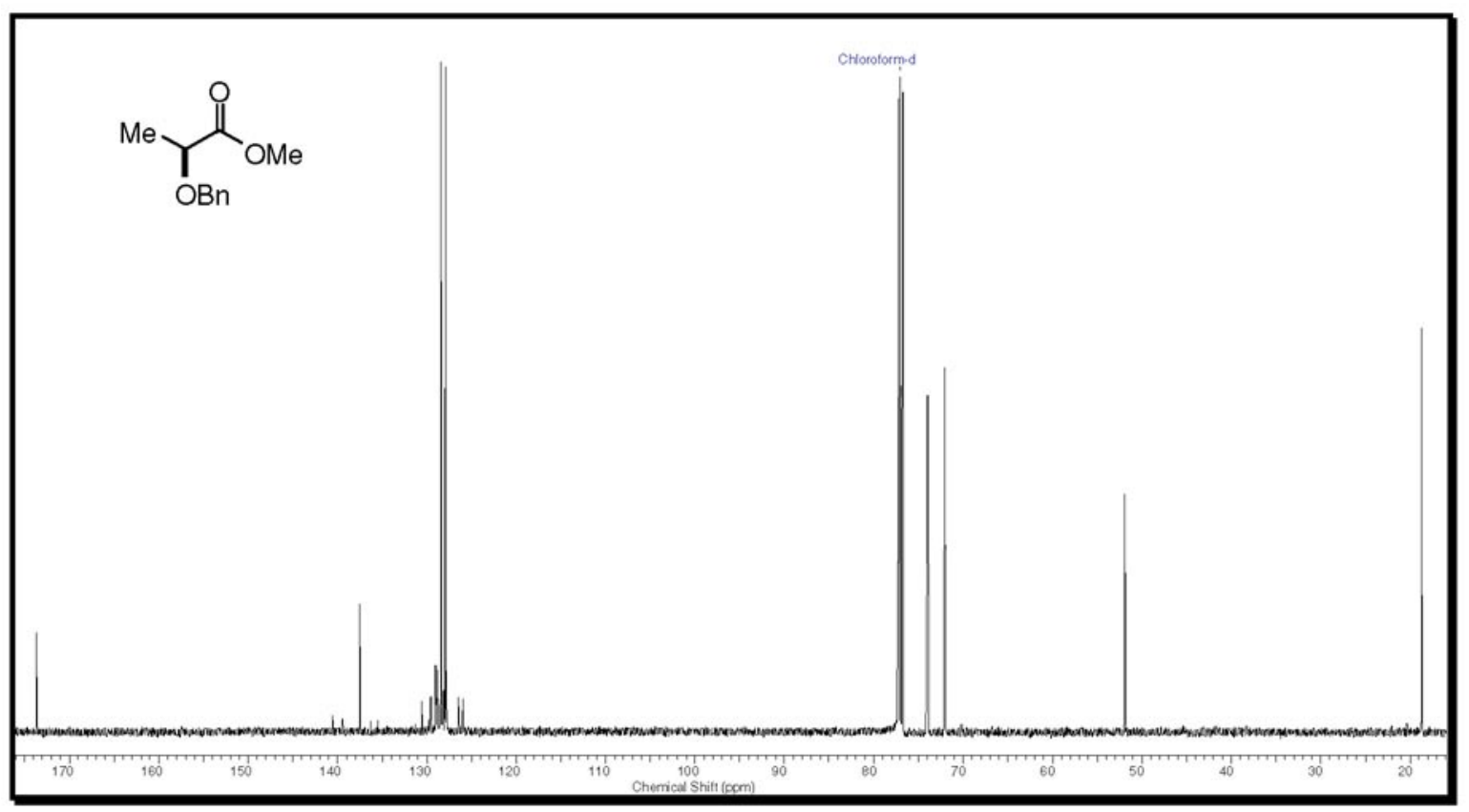

Figure 12S. ${ }^{13} \mathrm{C} \mathrm{NMR}\left(\mathrm{CDCl}_{3}, 75 \mathrm{MHz}\right)$. 


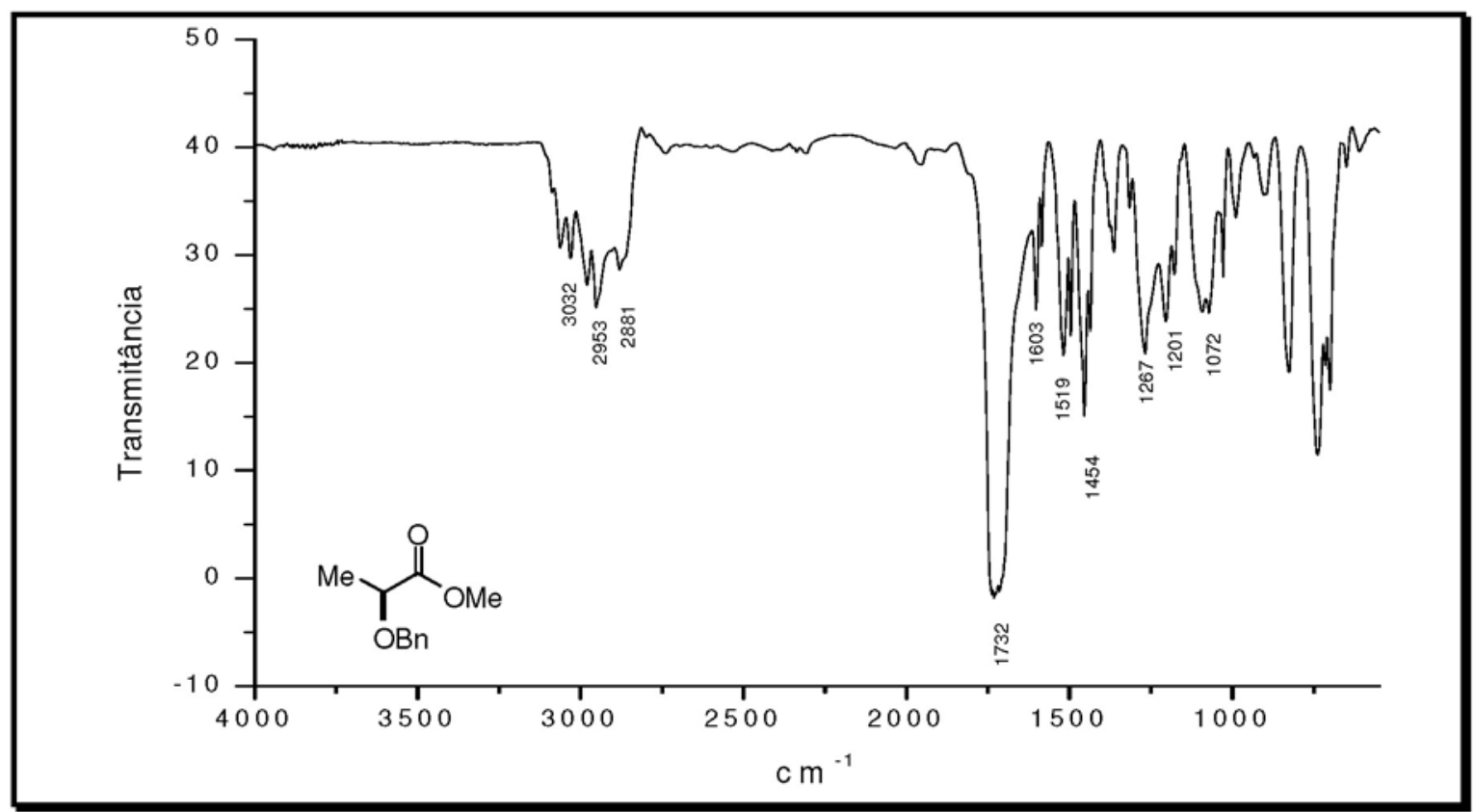

Figure 13S. IR (film).

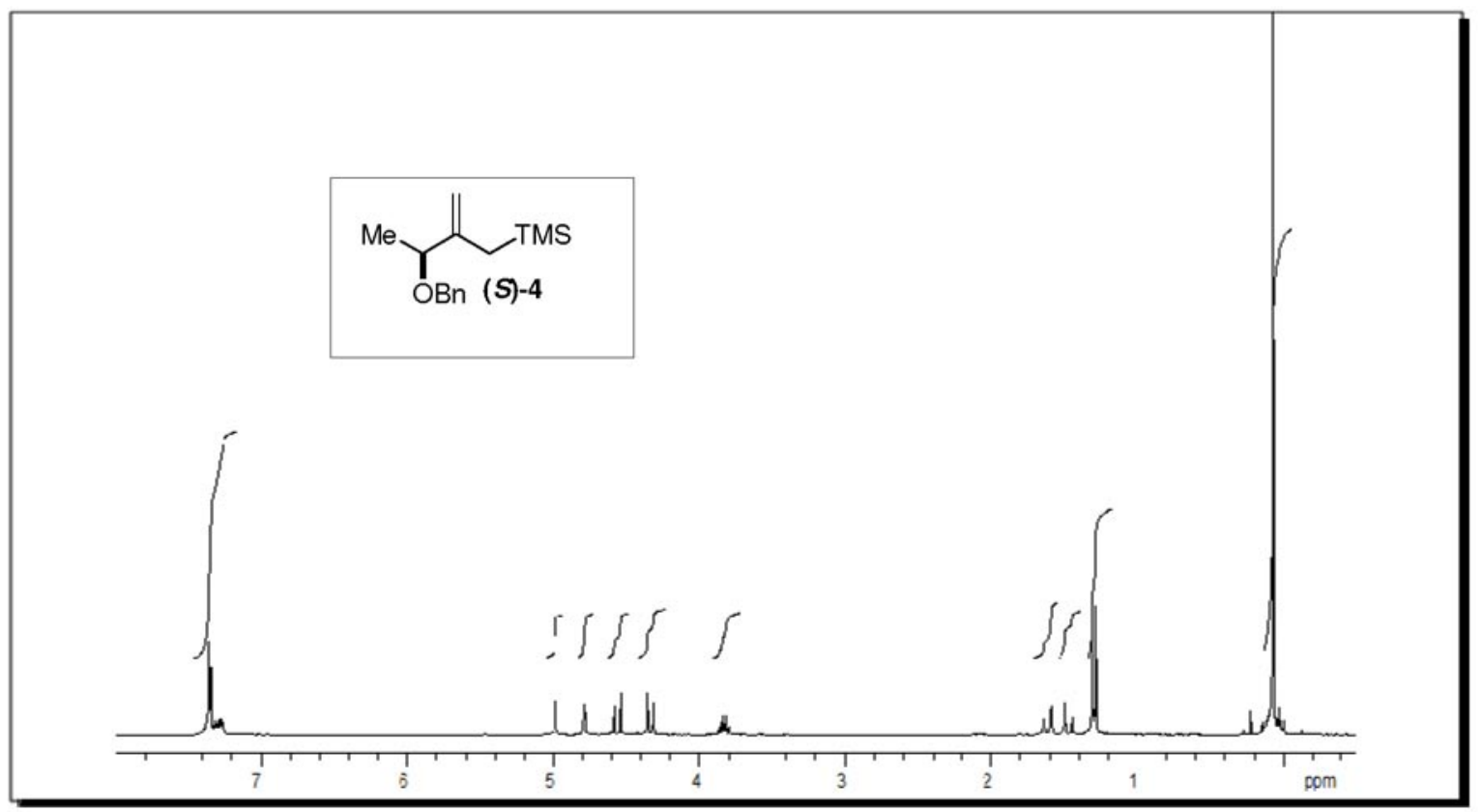

Figure 14S. ${ }^{1} \mathrm{H}$ NMR $\left(\mathrm{CDCl}_{3}, 300 \mathrm{MHz}\right)$ - (S)-(3-(benzyloxy)-2-methylenebutyl)trimethylsilane (4). 


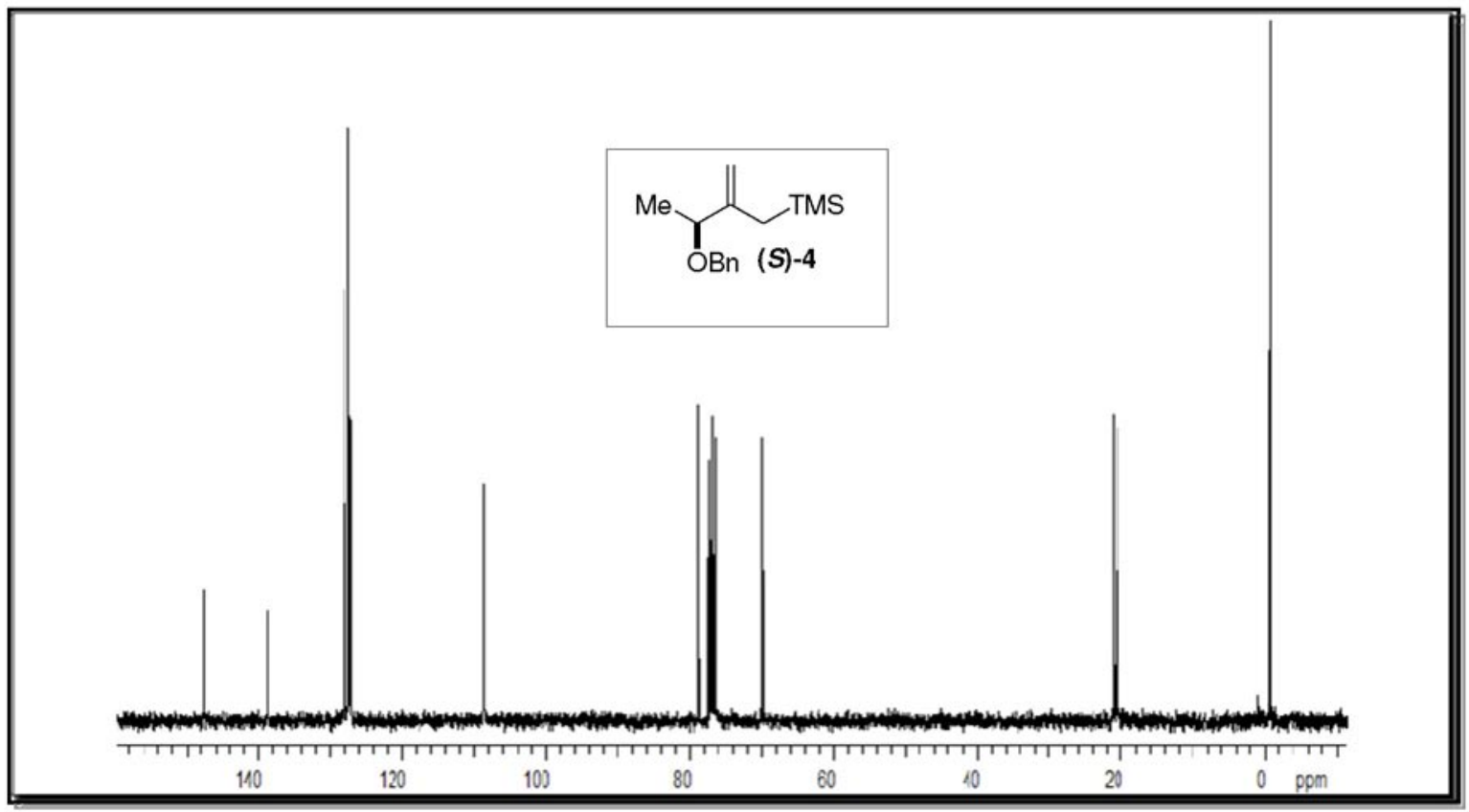

Figure 15S. ${ }^{13} \mathrm{C} \mathrm{NMR}\left(\mathrm{CDCl}_{3}, 75 \mathrm{MHz}\right)$ - (S)-(3-(benzyloxy)-2-methylenebutyl)trimethylsilane (4).

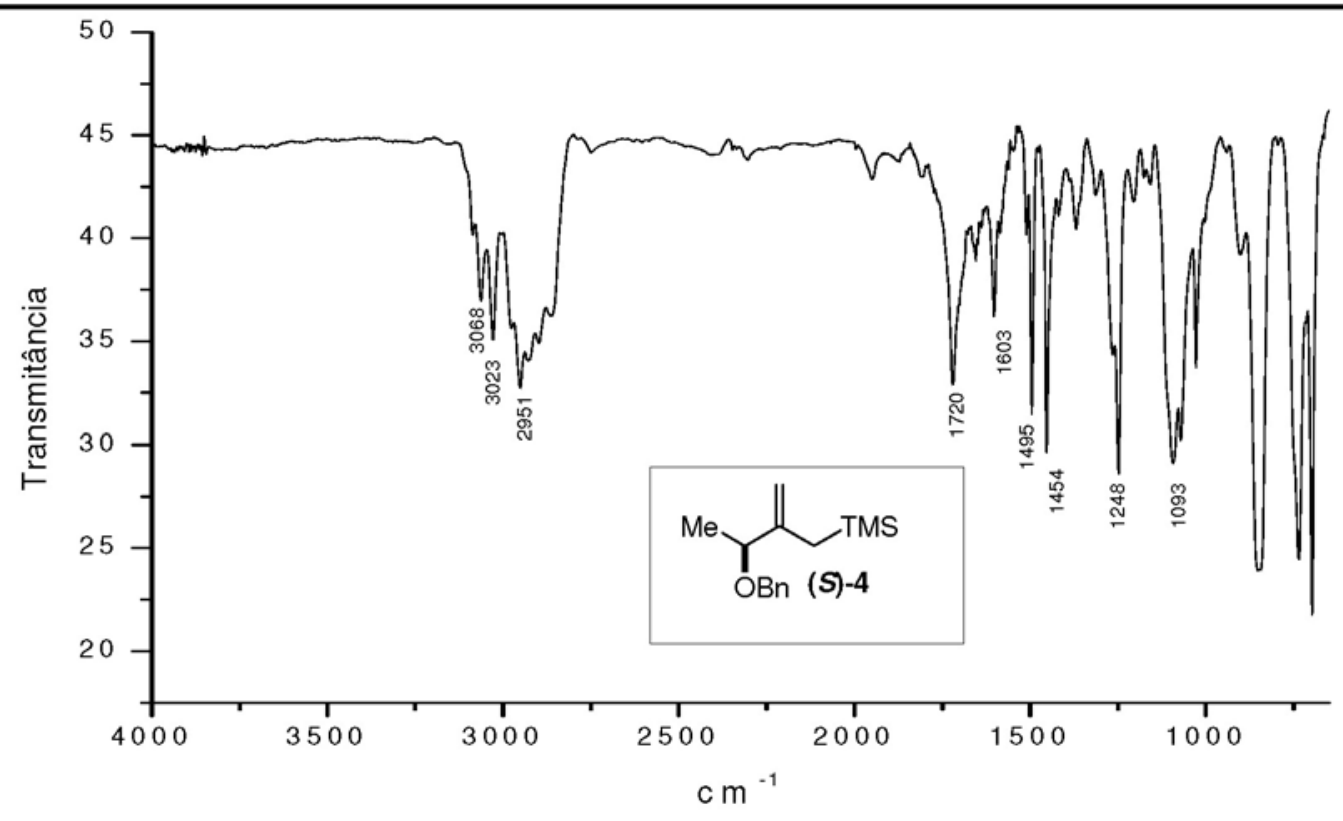

Figure 16S. IR (film) - (S)-(3-(benzyloxy)-2-methylenebutyl)trimethylsilane (4). 


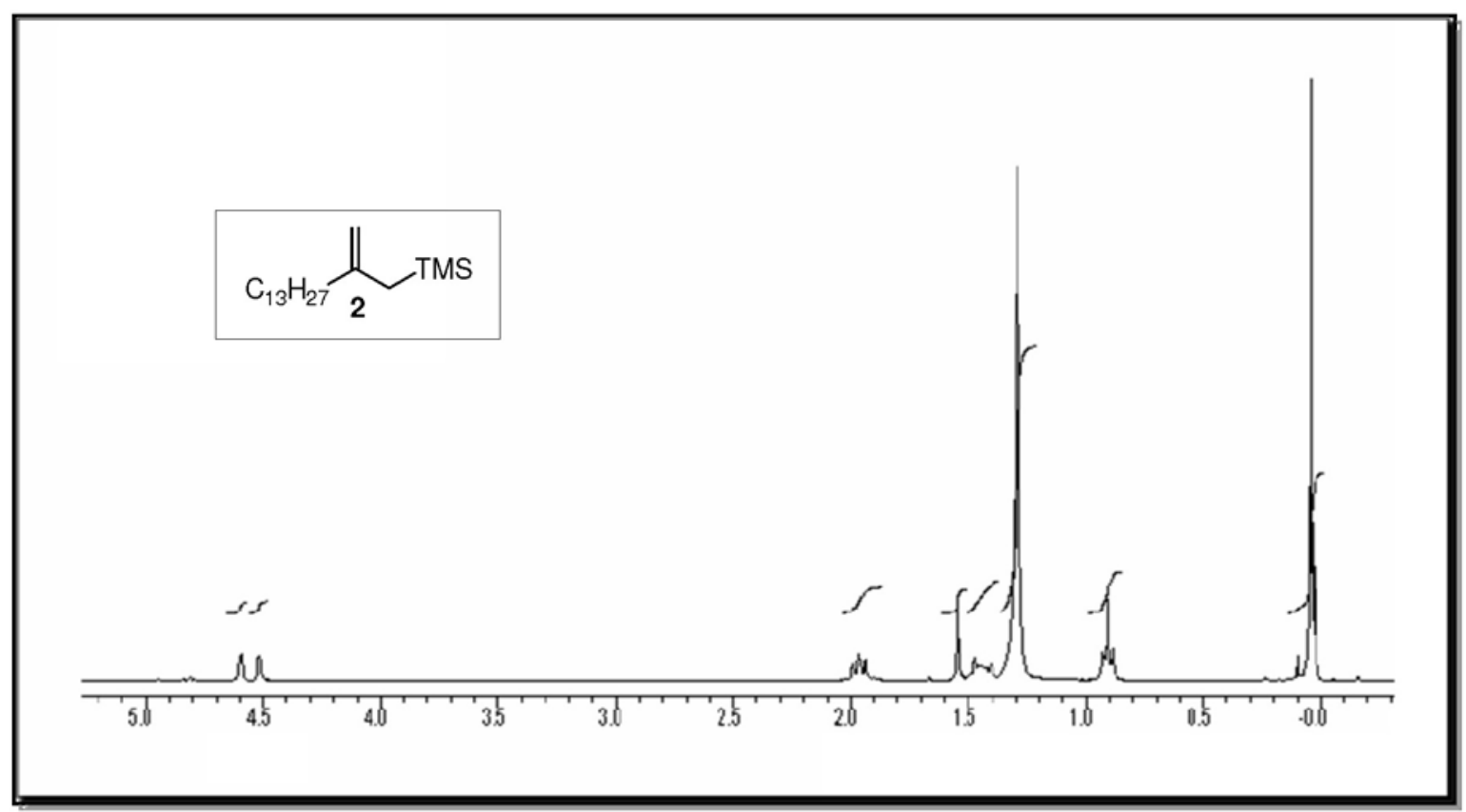

Figure 17S. ${ }^{1} \mathrm{H} \mathrm{NMR}\left(\mathrm{CDCl}_{3}, 300 \mathrm{MHz}\right)$ - Trimethyl(2-methylenepentadecyl)silane (2).

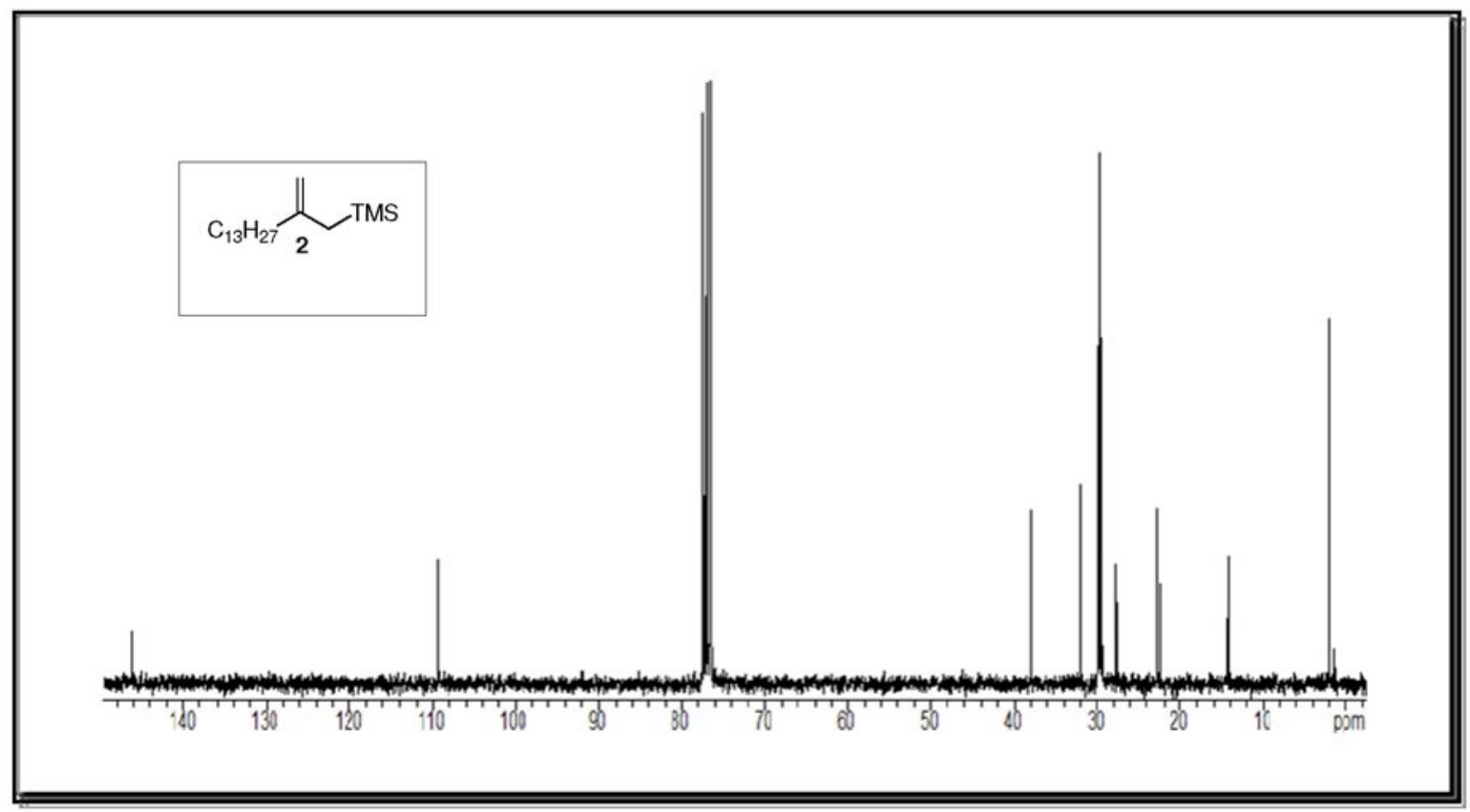

Figure 18S. ${ }^{13} \mathrm{C} \mathrm{NMR}\left(\mathrm{CDCl}_{3}, 75 \mathrm{MHz}\right)$ - Trimethyl(2-methylenepentadecyl)silane (2). 


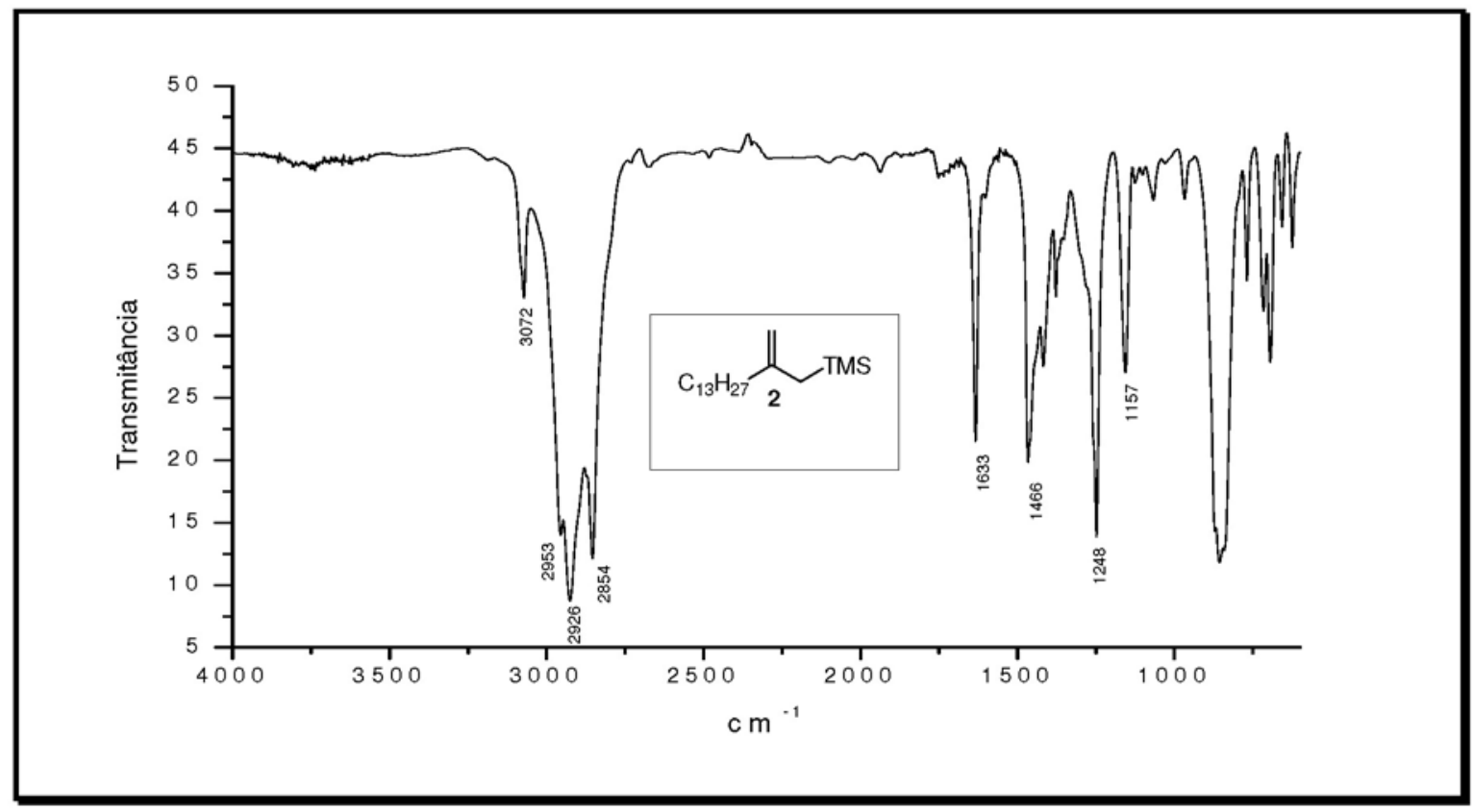

Figure 19S. IR (film) - Trimethyl(2-methylenepentadecyl)silane (2).

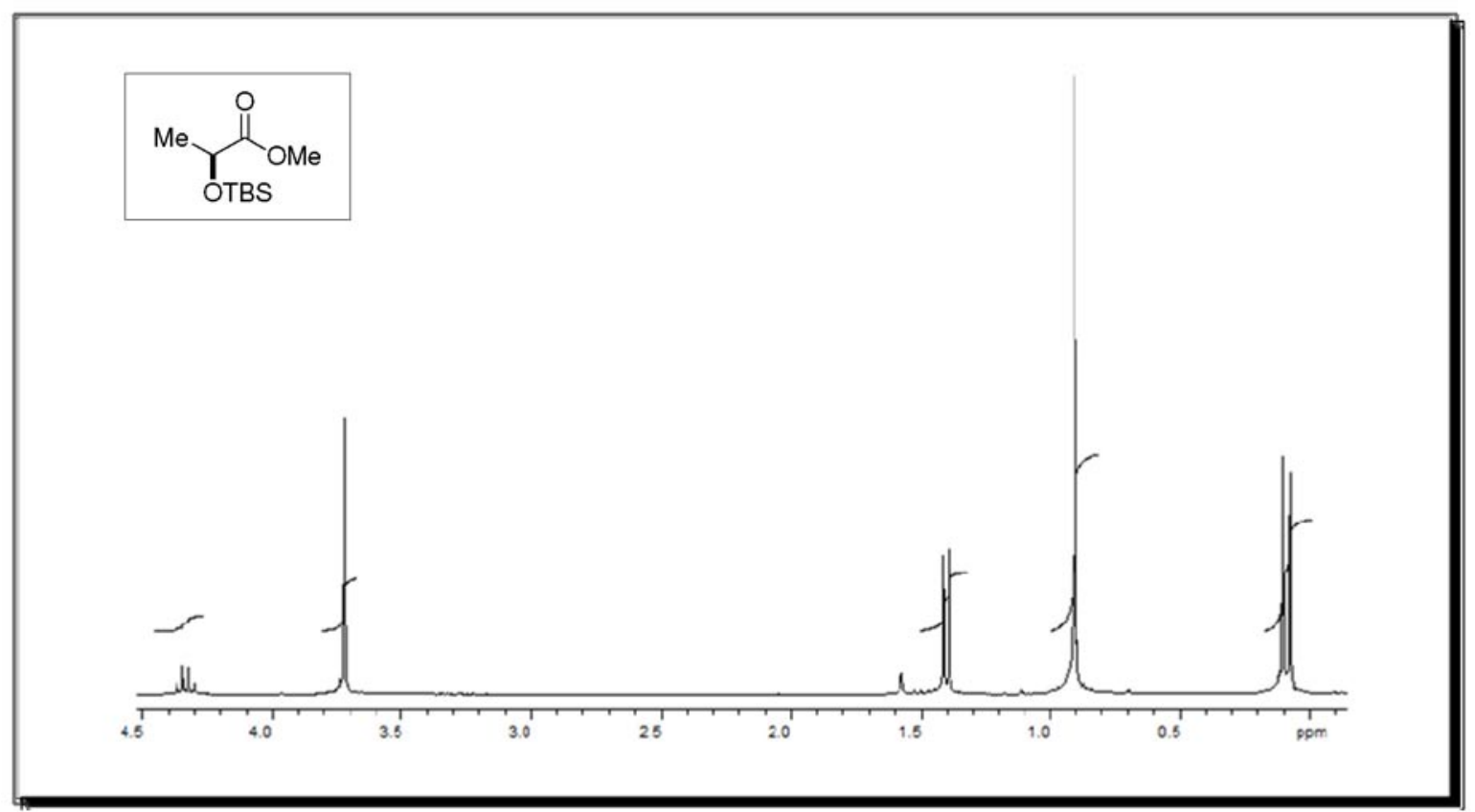

Figure 20S. ${ }^{1} \mathrm{H}$ NMR $\left(\mathrm{CDCl}_{3}, 300 \mathrm{MHz}\right)$. 
Vol. 00, No. 00, 2009

Dias et al.

S17

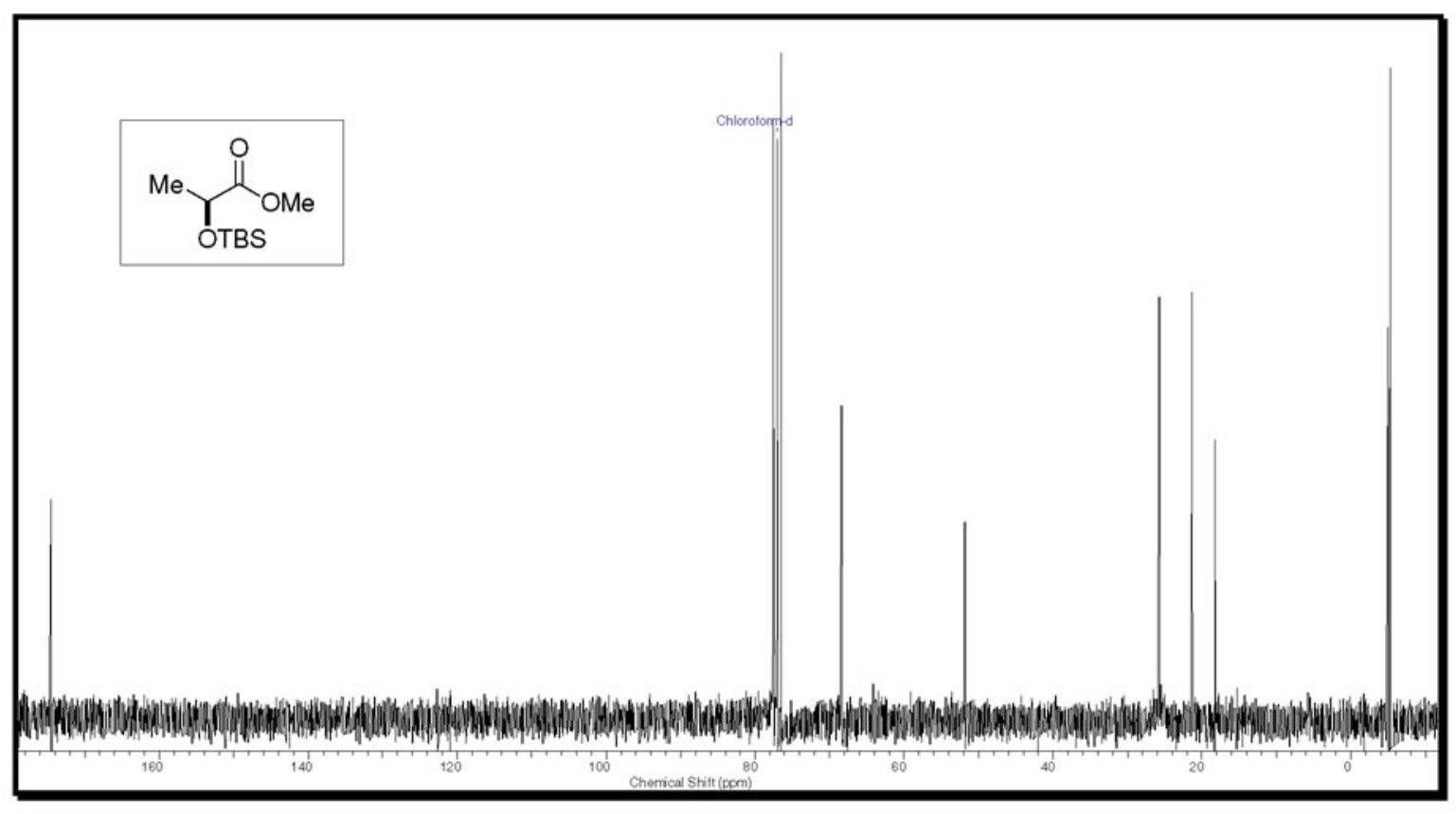

Figure 21S. ${ }^{13} \mathrm{C} \mathrm{NMR}\left(\mathrm{CDCl}_{3}, 63 \mathrm{MHz}\right)$.

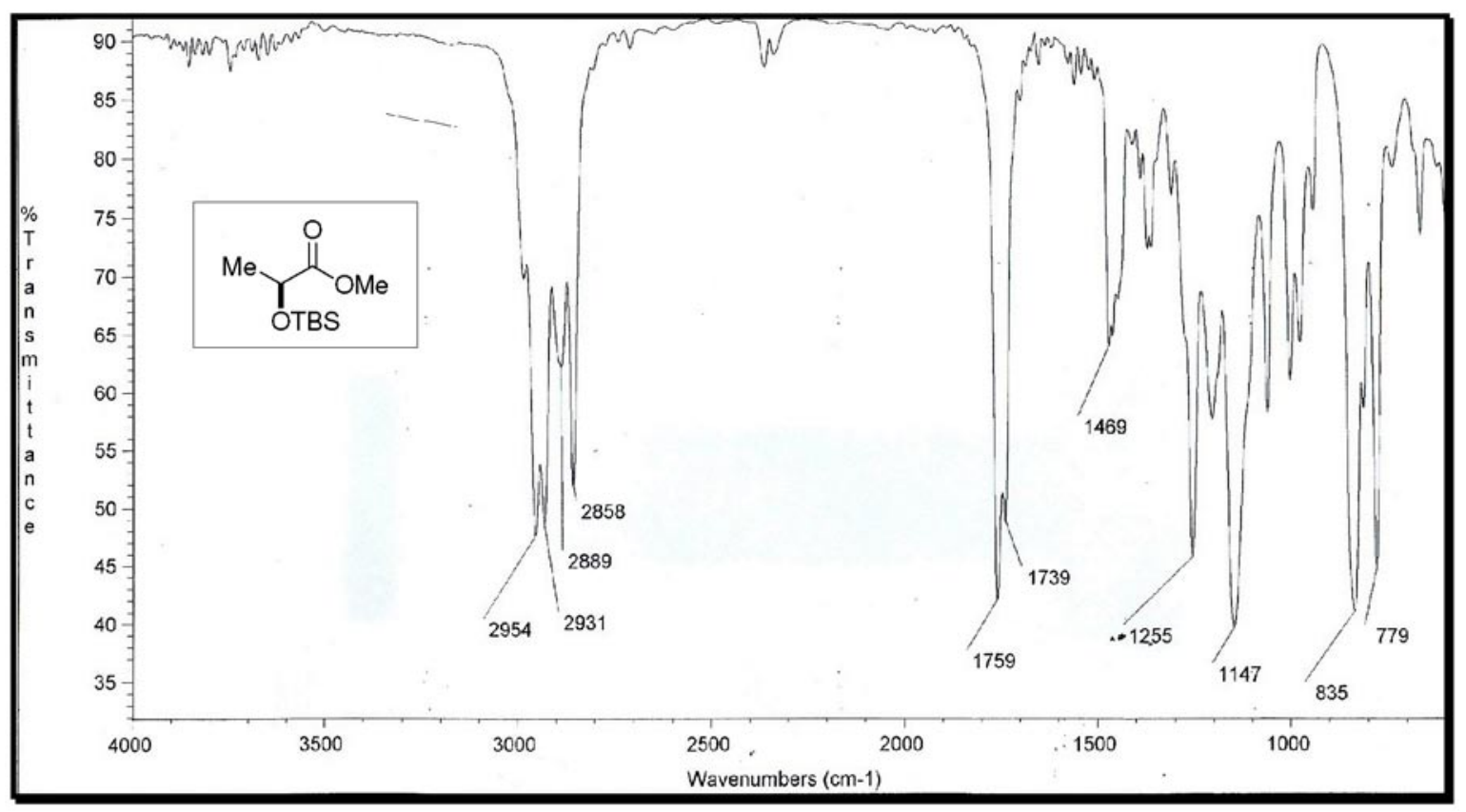

Figure 22S. IR (film). 


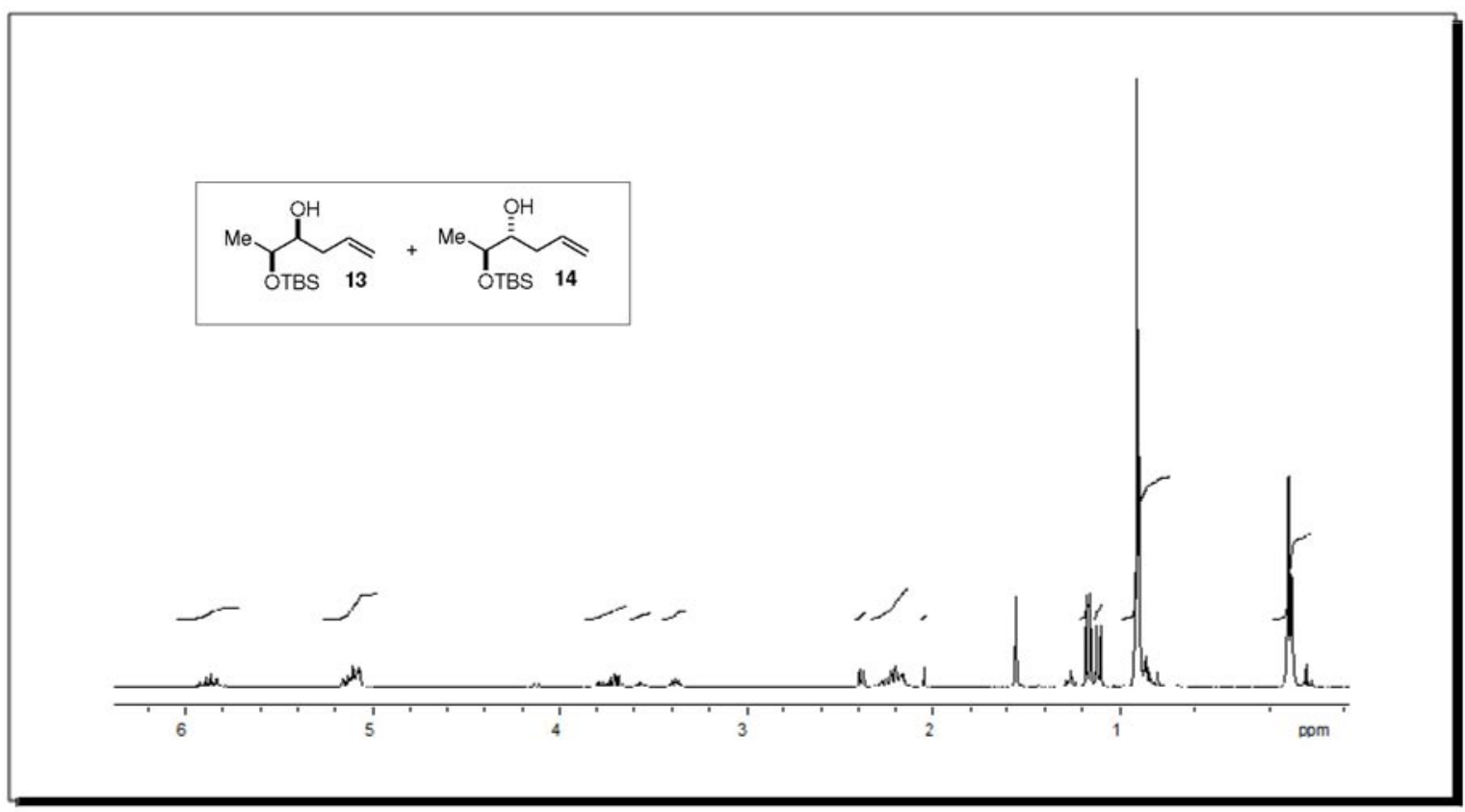

Figure 23S. ${ }^{1} \mathrm{H}$ NMR $\left(\mathrm{CDCl}_{3}, 300 \mathrm{MHz}\right)$ - (2S,3S)-2-(tert-butyldimethylsilyloxy)hex-5-en-3-ol (13) and (2S,3R)-2-(tert-butyldimethylsilyloxy)hex-5en-3-ol (14).

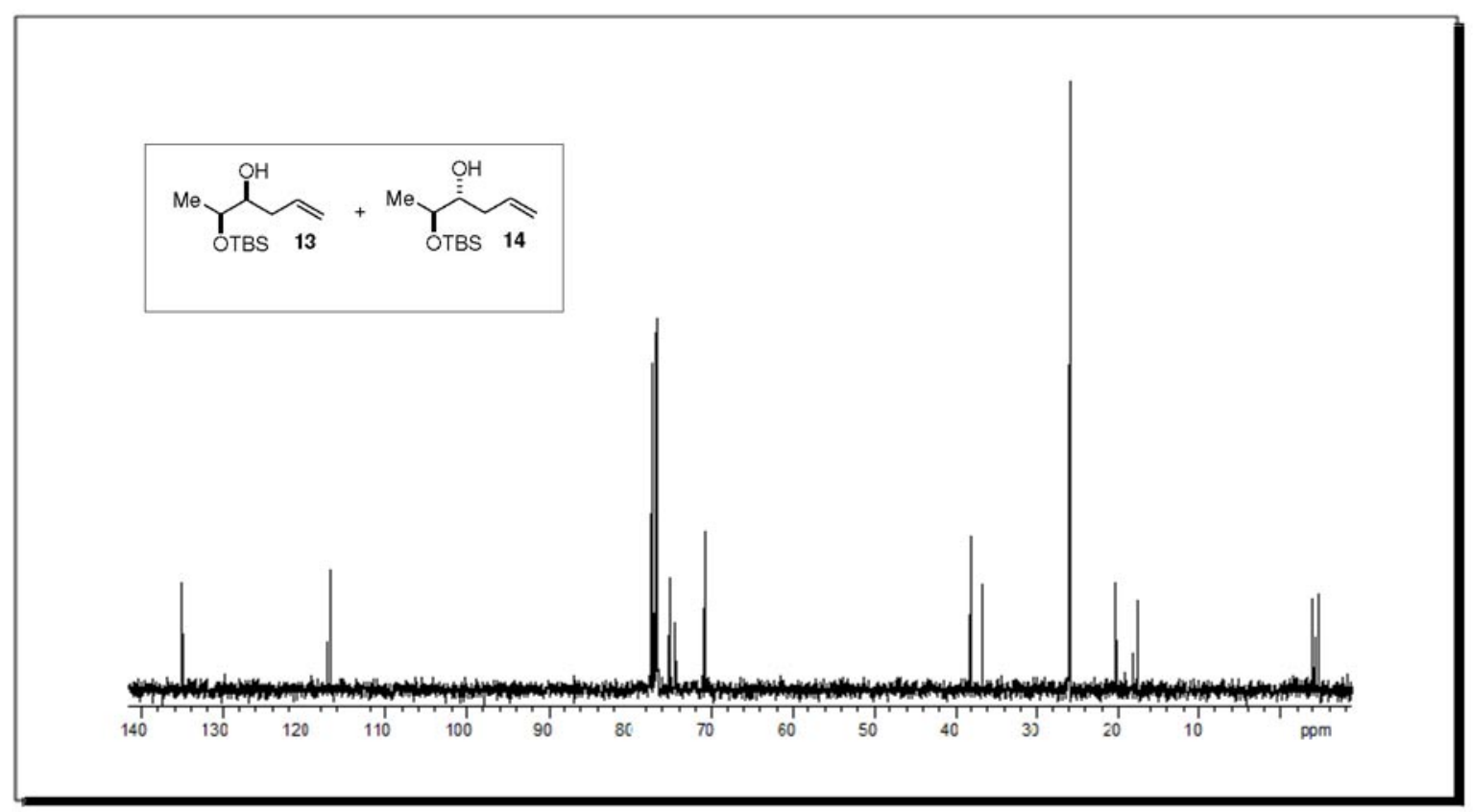

Figure 24S. ${ }^{13} \mathrm{C}$ NMR $\left(\mathrm{CDCl}_{3}, 75 \mathrm{MHz}\right)$ - (2S,3S)-2-(tert-butyldimethylsilyloxy)hex-5-en-3-ol (13) and (2S,3R)-2-(tert-butyldimethylsilyloxy)hex-5en-3-ol (14). 
Vol. 00, No. 00, 2009

Dias et al.

S19

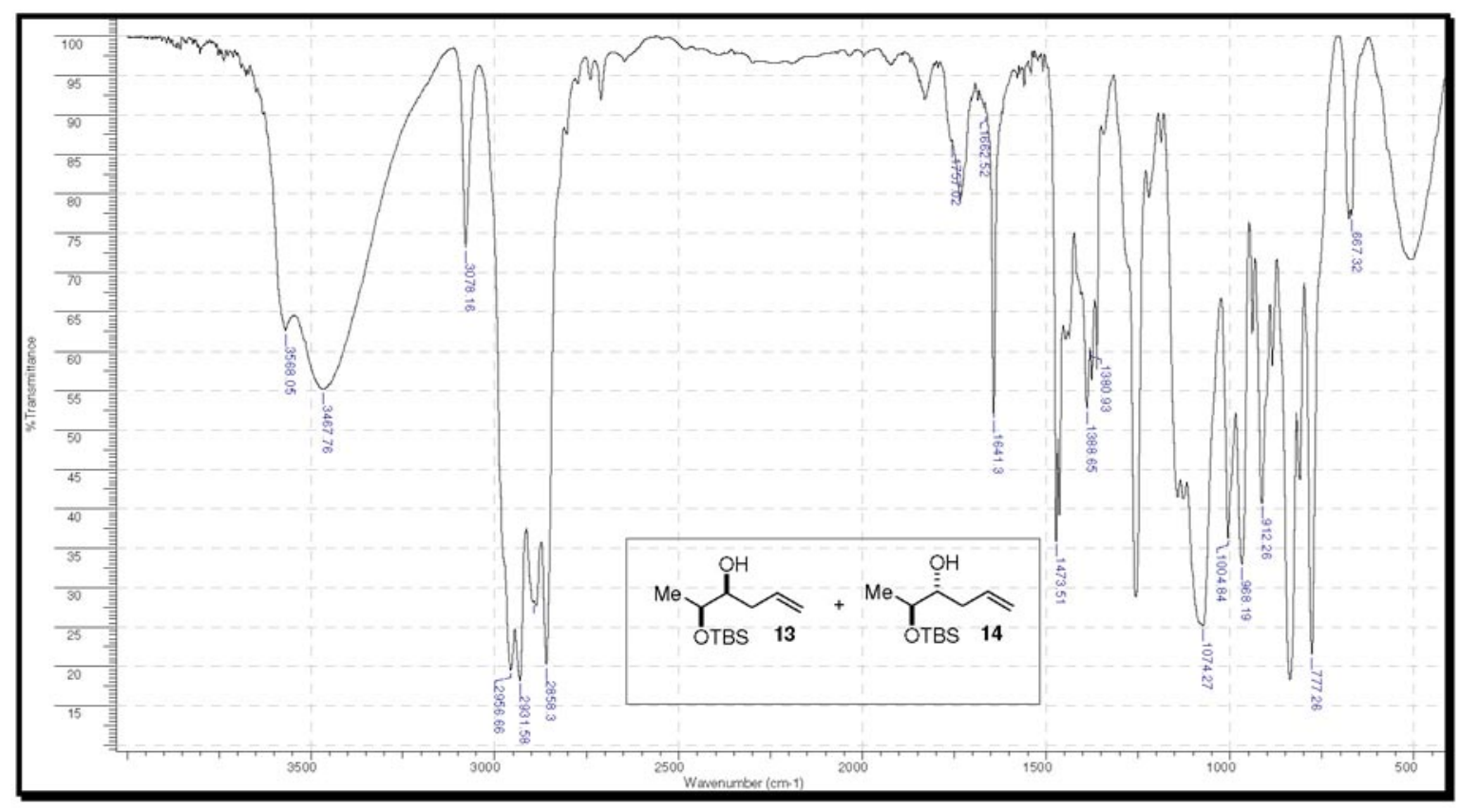

Figure 25S. IR (film) - (2S,3S)-2-(tert-butyldimethylsilyloxy)hex-5-en-3-ol (13) and (2S,3R)-2-(tert-butyldimethylsilyloxy)hex-5-en-3-ol (14).

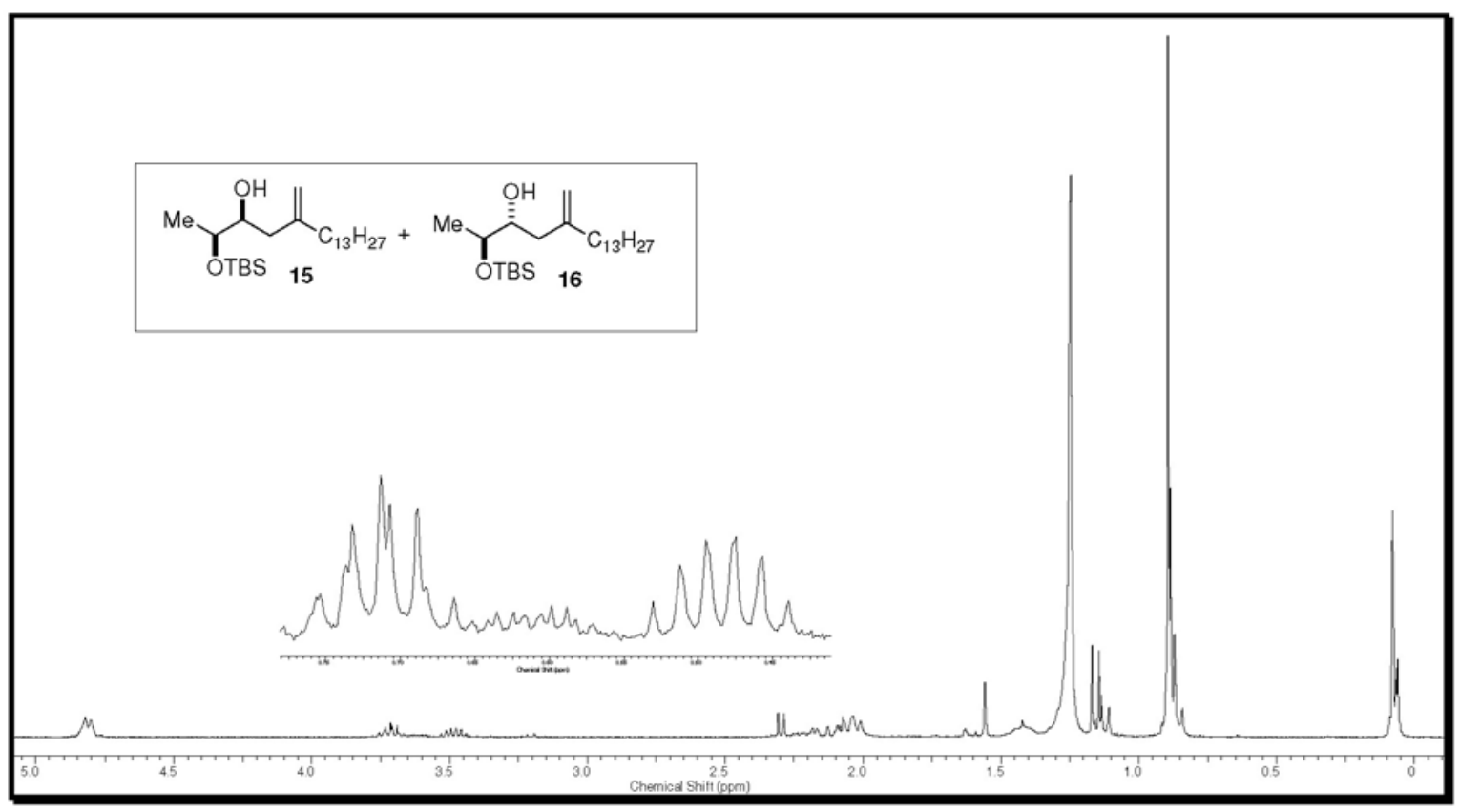

Figure 26S. ${ }^{1} \mathrm{H}$ NMR $\left(\mathrm{CDCl}_{3}, 300 \mathrm{MHz}\right)$ - (2S,3S)-2-(tert-butyldimethylsilyloxy)-5-methyleneoctadecan-3-ol (15) and (2S,3R)-2-(tertbutyldimethylsilyloxy)-5-methyleneoctadecan-3-ol (16). 


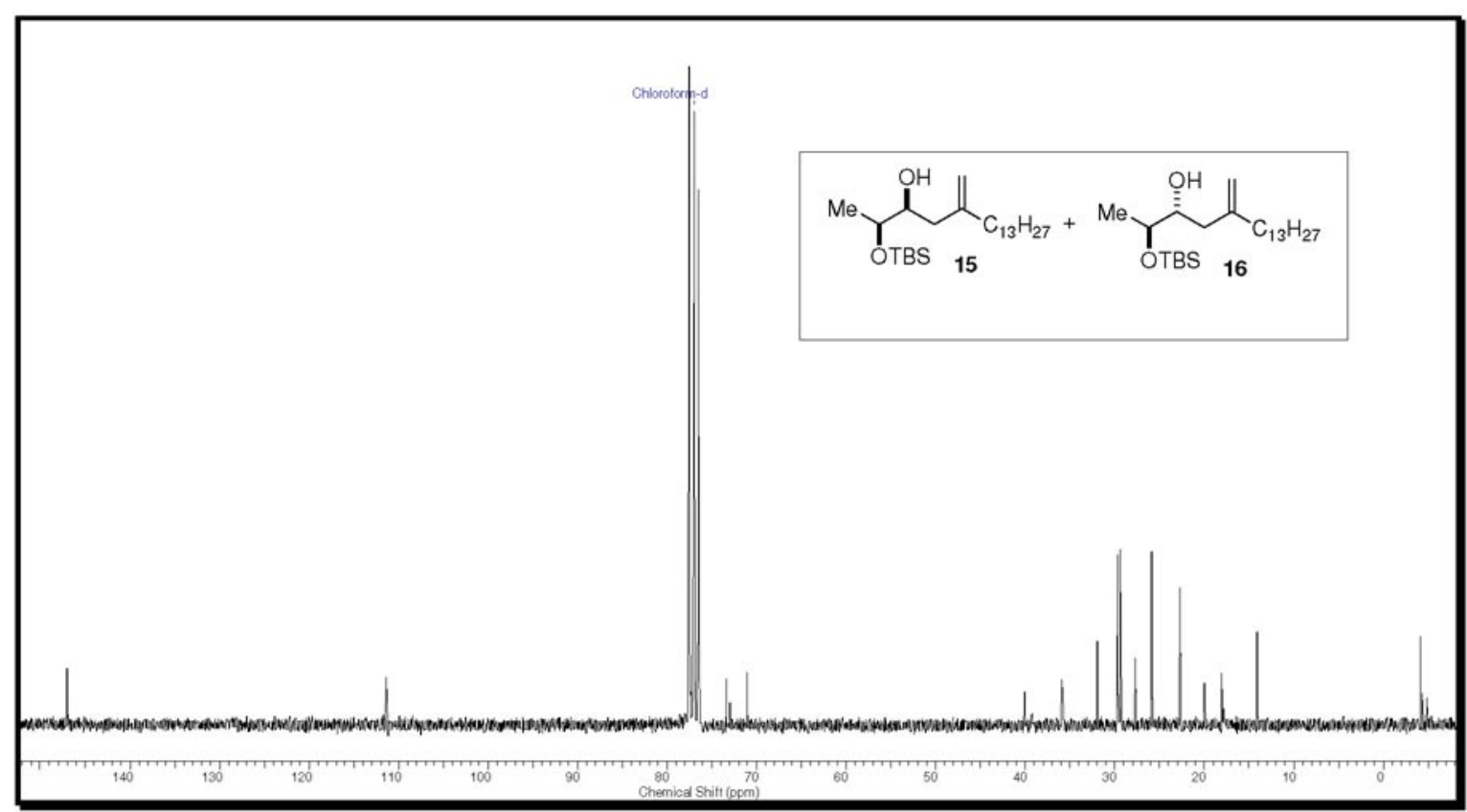

Figure 27S. ${ }^{13} \mathrm{C}$ NMR $\left(\mathrm{CDCl}_{3}, 63 \mathrm{MHz}\right)$ - (2S,3S)-2-(tert-butyldimethylsilyloxy)-5-methyleneoctadecan-3-ol (15) and (2S,3R)-2-(tertbutyldimethylsilyloxy)-5-methyleneoctadecan-3-ol (16).

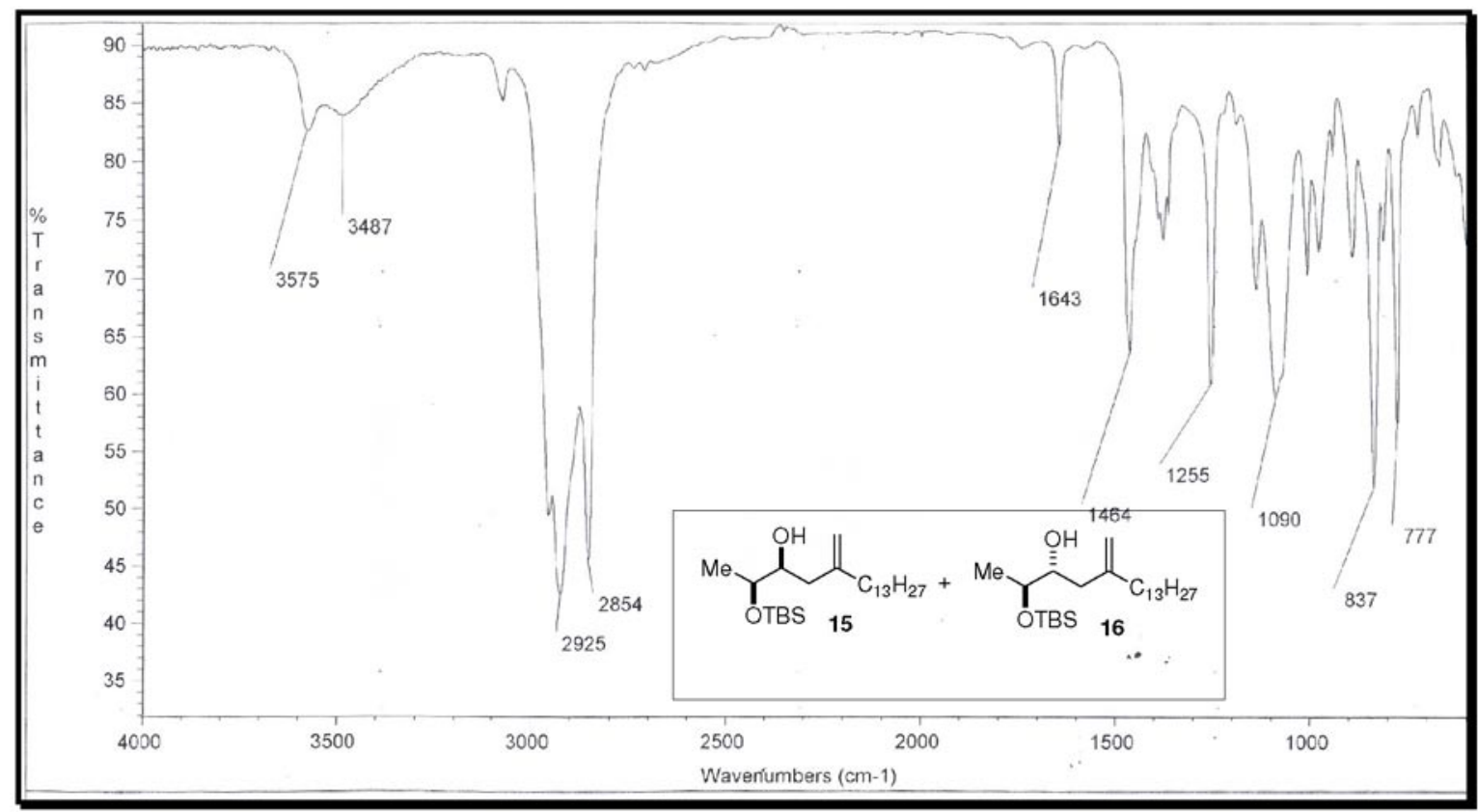

Figure 28S. IR (film) - (2S,3S)-2-(tert-butyldimethylsilyloxy)-5-methyleneoctadecan-3-ol (15) and (2S,3R)-2-(tert-butyldimethylsilyloxy)-5methyleneoctadecan-3-ol (16). 


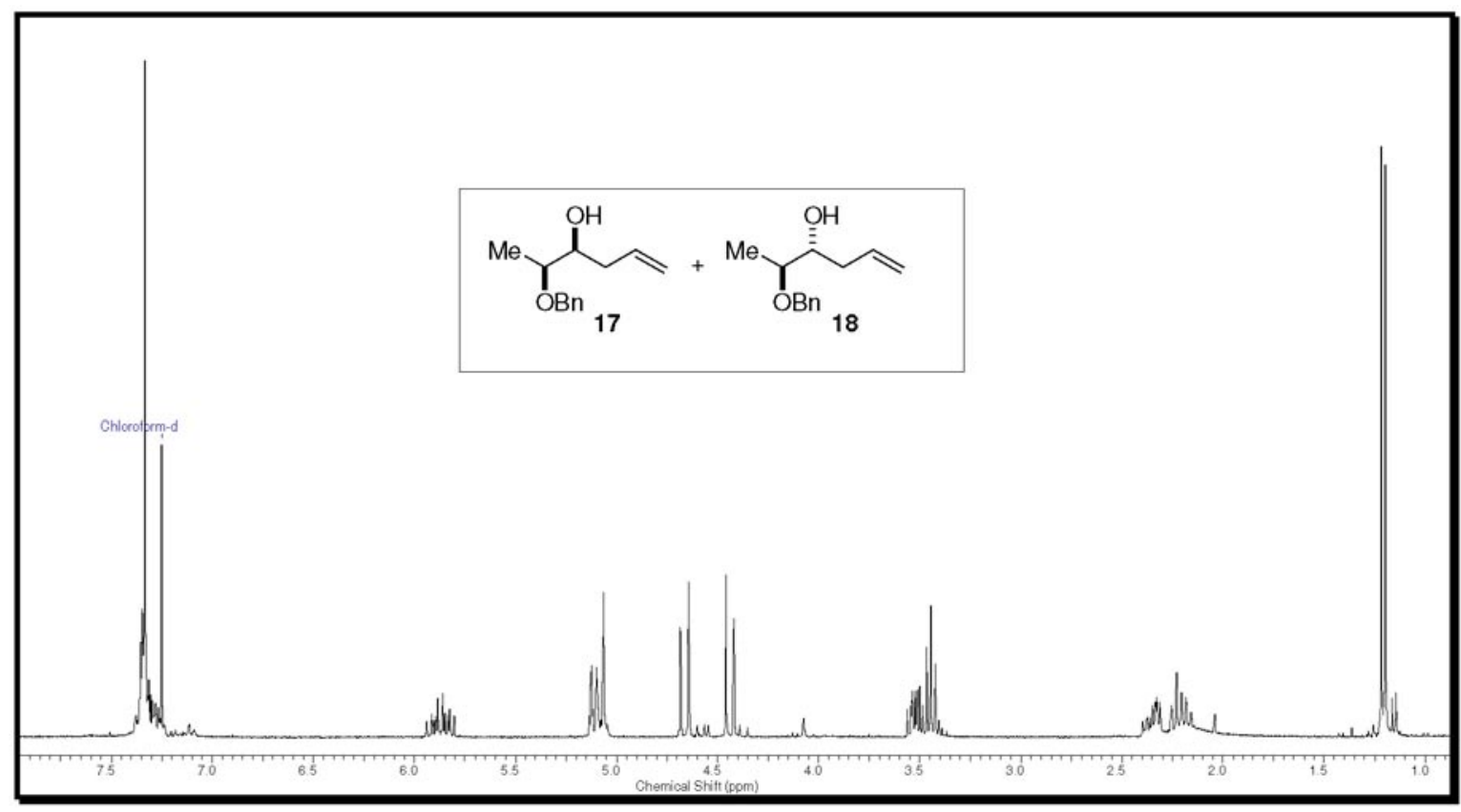

Figure 29S. ${ }^{1} \mathrm{H}$ NMR $\left(\mathrm{CDCl}_{3}, 500 \mathrm{MHz}\right)(2 S, 3 S)$-2-(benzyloxy)hex-5-en-3-ol (17) and (2S,3R)-2-(benzyloxy)hex-5-en-3-ol (18).

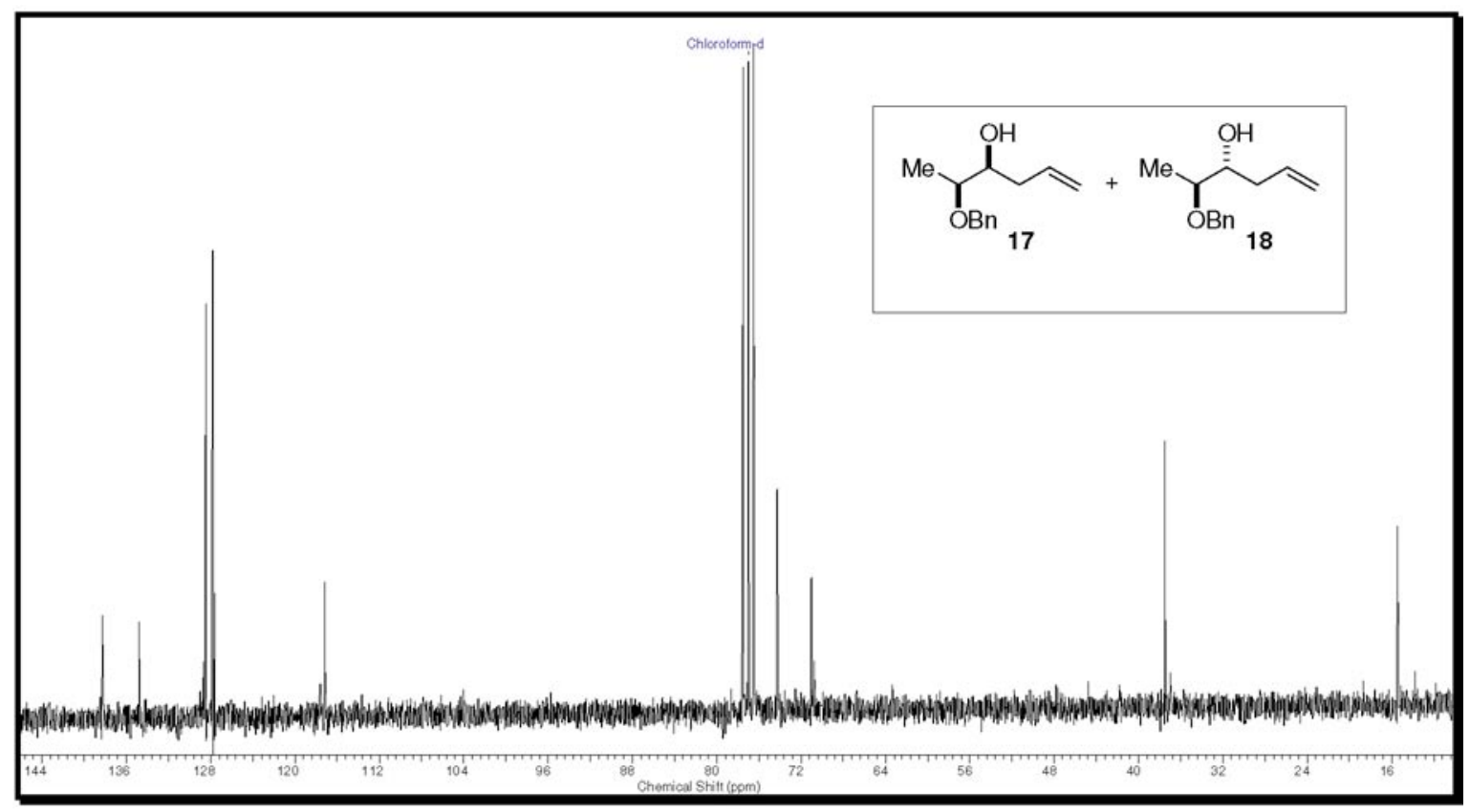

Figure 30S. ${ }^{13} \mathrm{C}$ NMR $\left(\mathrm{CDCl}_{3}, 63 \mathrm{MHz}\right)$ - (2S,3S)-2-(benzyloxy)hex-5-en-3-ol (17) and (2S,3R)-2-(benzyloxy)hex-5-en-3-ol (18). 


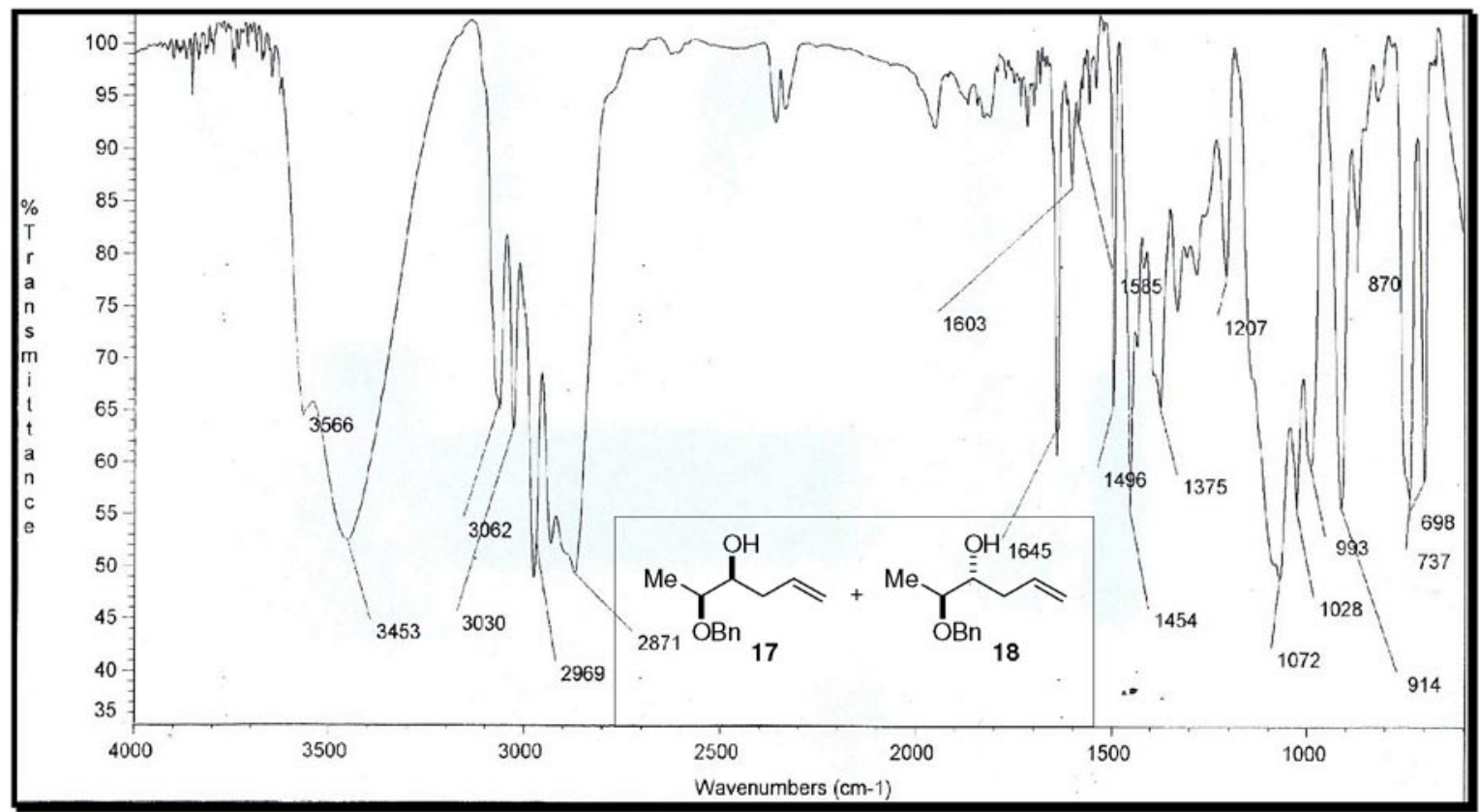

Figure 31S. IR (film) - (2S,3S)-2-(benzyloxy)hex-5-en-3-ol (17) and (2S,3R)-2-(benzyloxy)hex-5-en-3-ol (18).

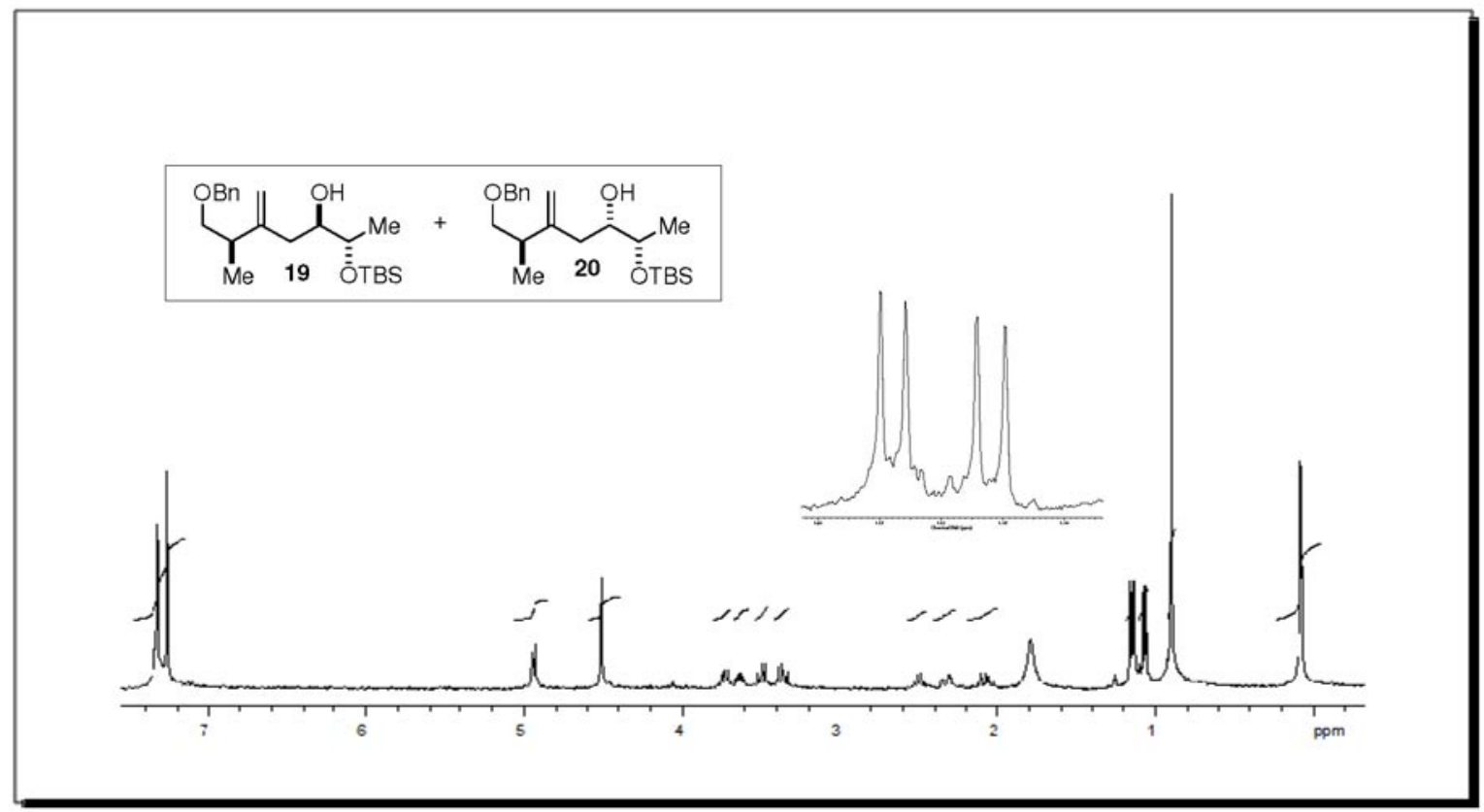

Figure 32S. ${ }^{1} \mathrm{H} \mathrm{NMR}\left(\mathrm{CDCl}_{3}, 300 \mathrm{MHz}\right)$ - (2S,3R,6R)-7-(benzyloxy)-2-(tert-butyldimethylsilyloxy)-6-methyl-5-methyleneheptan-3-ol (19) and (2S,3S,6R)-7-(benzyloxy)-2-(tert-butyldimethylsilyloxy)-6-methyl-5-methyleneheptan-3-ol (20). 


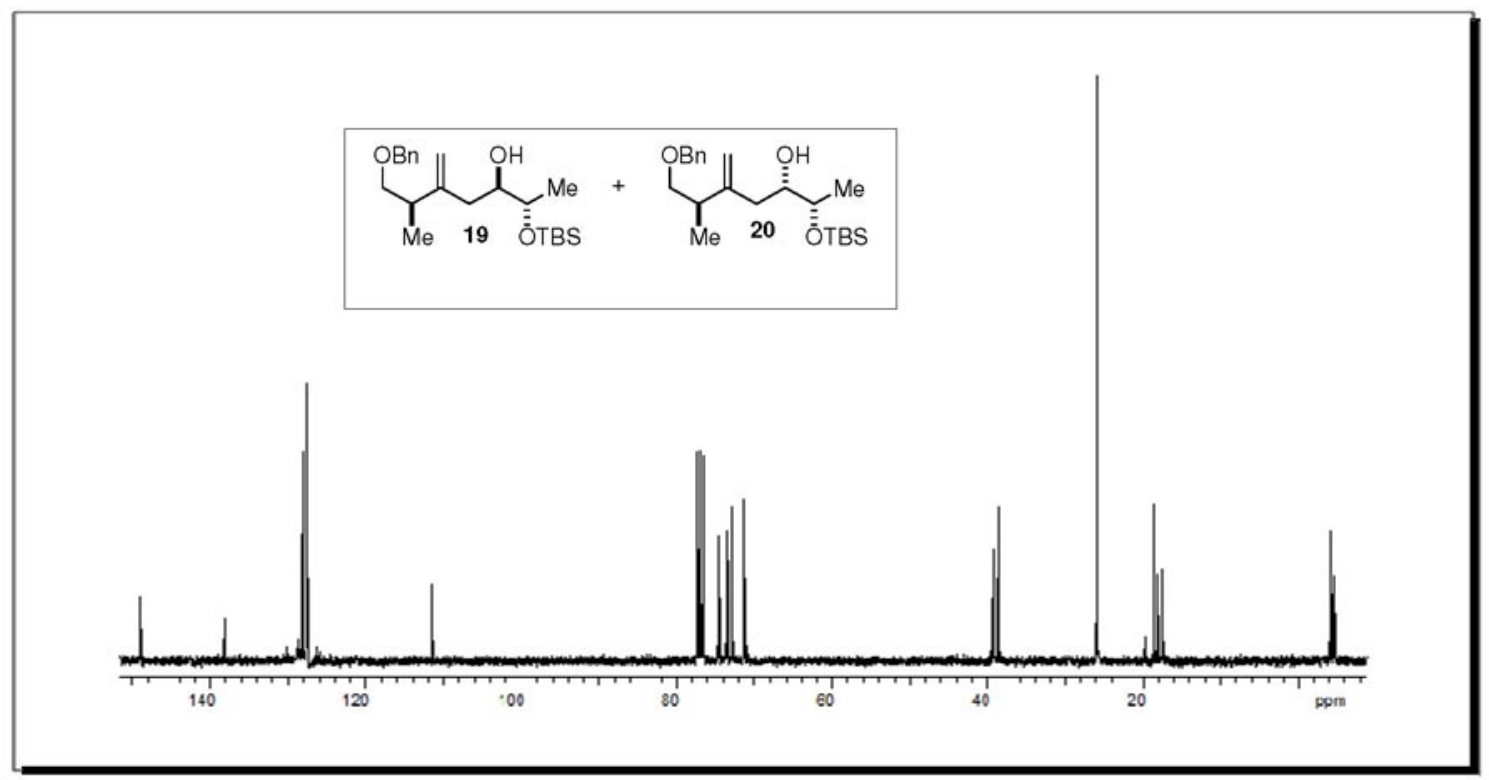

Figure 33S. ${ }^{13} \mathrm{C}$ NMR $\left(\mathrm{CDCl}_{3}, 75 \mathrm{MHz}\right)$ - (2S,3R,6R)-7-(benzyloxy)-2-(tert-butyldimethylsilyloxy)-6-methyl-5-methyleneheptan-3-ol (19) and $(2 S, 3 S, 6 R)$-7-(benzyloxy)-2-(tert-butyldimethylsilyloxy)-6-methyl-5-methyleneheptan-3-ol (20).

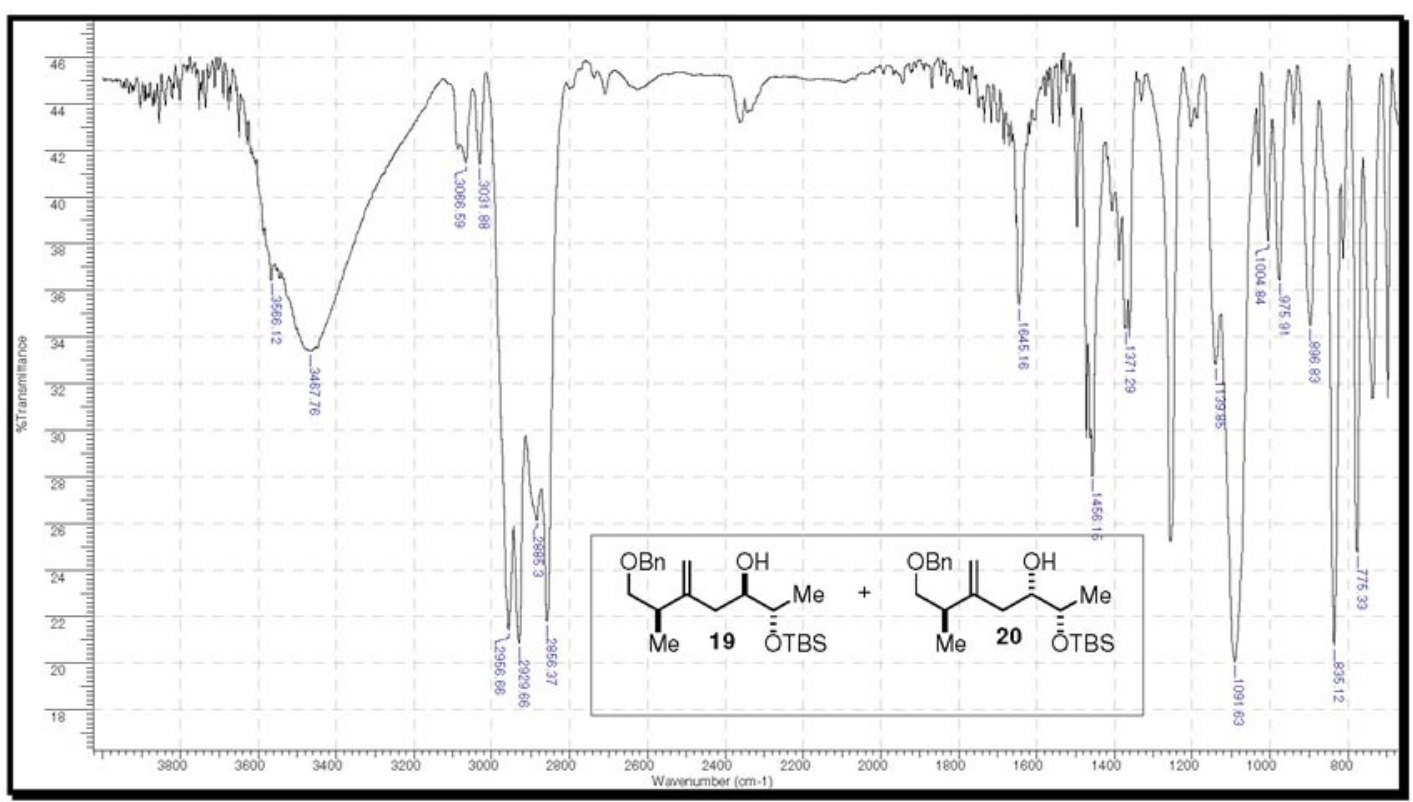

Figure 34S. IR (film) - (2S,3R,6R)-7-(benzyloxy)-2-(tert-butyldimethylsilyloxy)-6-methyl-5-methyleneheptan-3-ol (19) and (2S,3S,6R)-7-(benzyloxy)2-(tert-butyldimethylsilyloxy)-6-methyl-5-methyleneheptan-3-ol (20). 


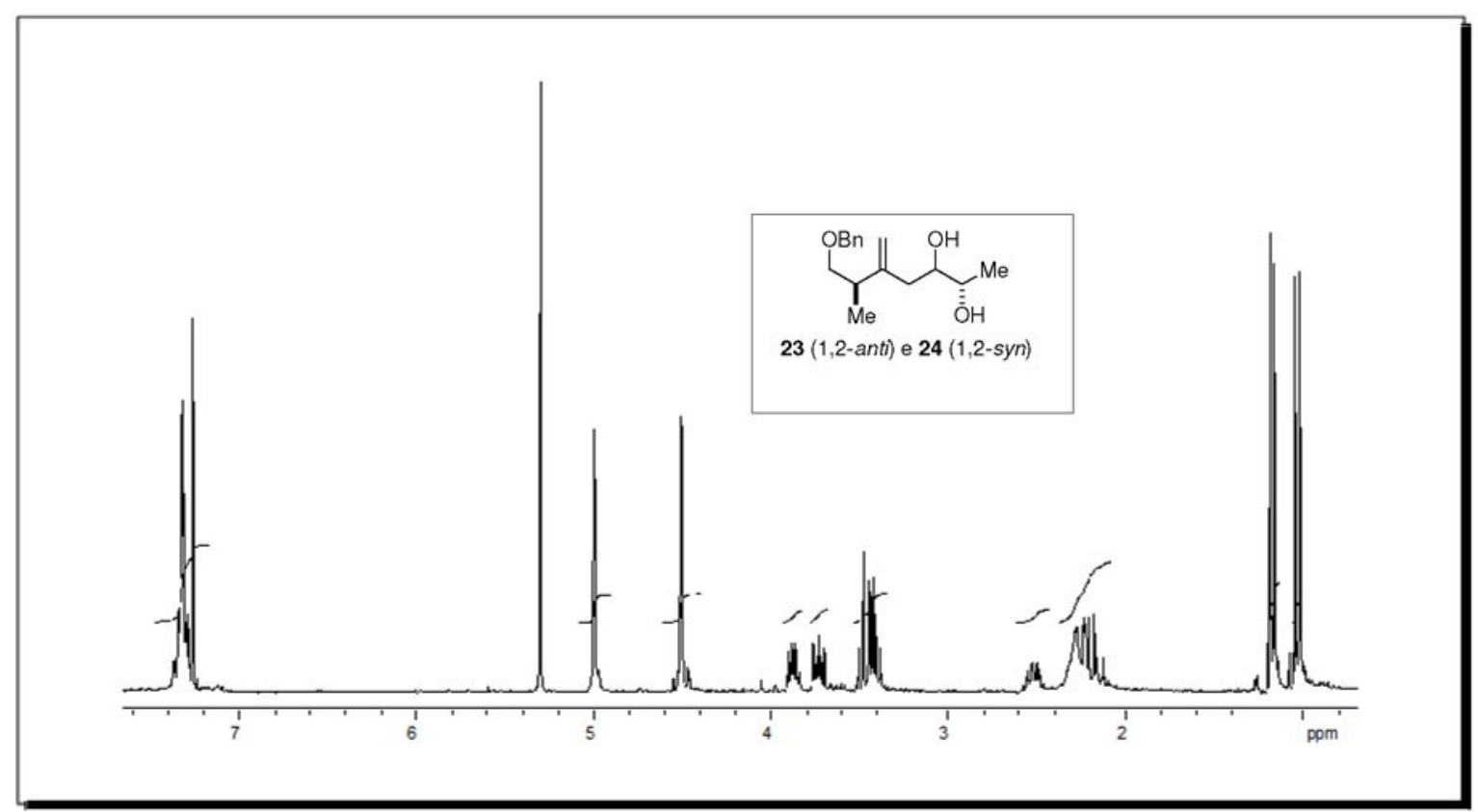

Figure 35S. ${ }^{1} \mathrm{H}$ NMR $\left(\mathrm{CDCl}_{3}, 300 \mathrm{MHz}\right)$ - (2S,6R)-7-(benzyloxy)-6-methyl-5-methyleneheptane-2,3-diols (23) and (24).

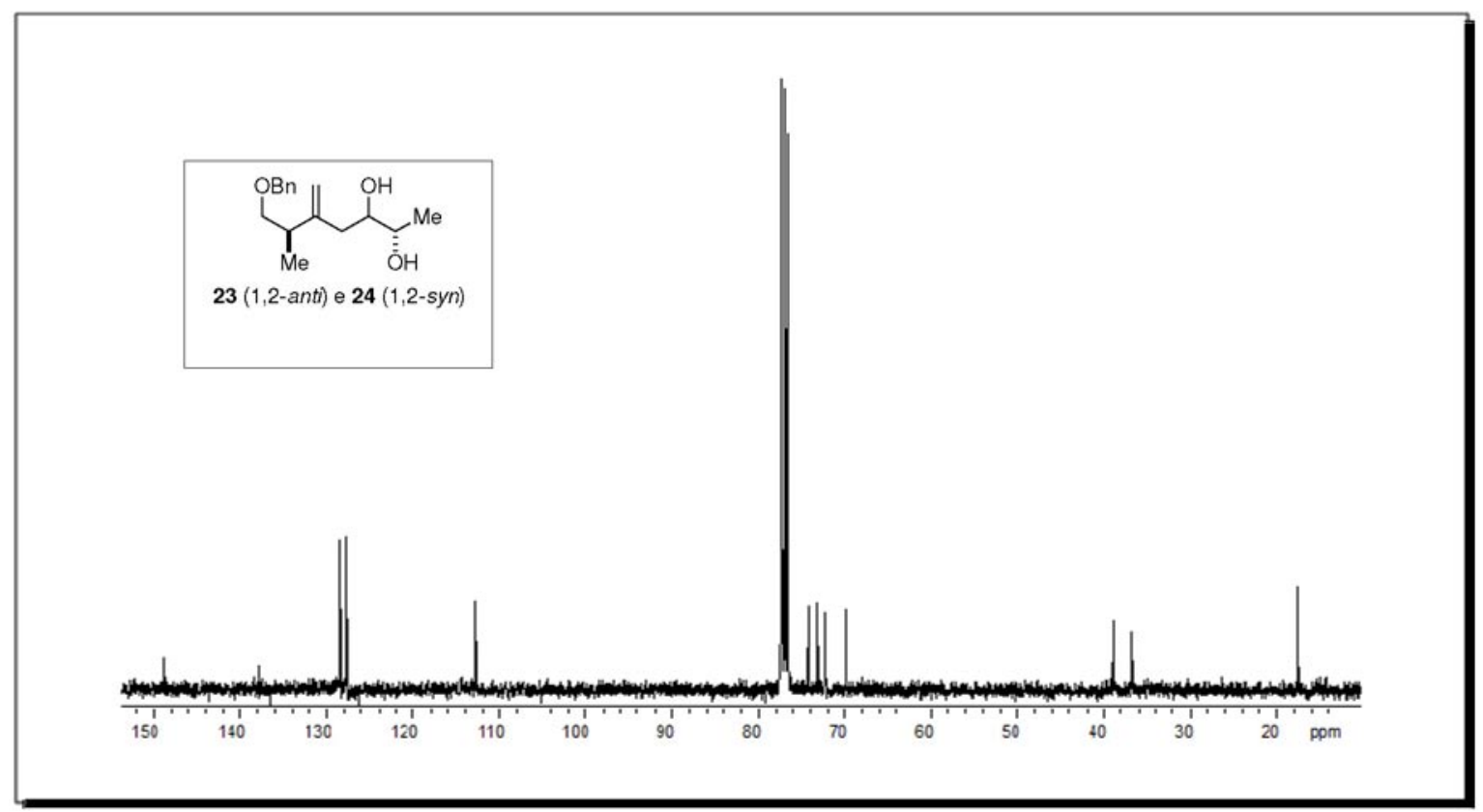

Figure 36S. ${ }^{13} \mathrm{C} \mathrm{NMR}\left(\mathrm{CDCl}_{3}, 75 \mathrm{MHz}\right)$ - (2S,6R)-7-(benzyloxy)-6-methyl-5-methyleneheptane-2,3-diols (23) and (24). 


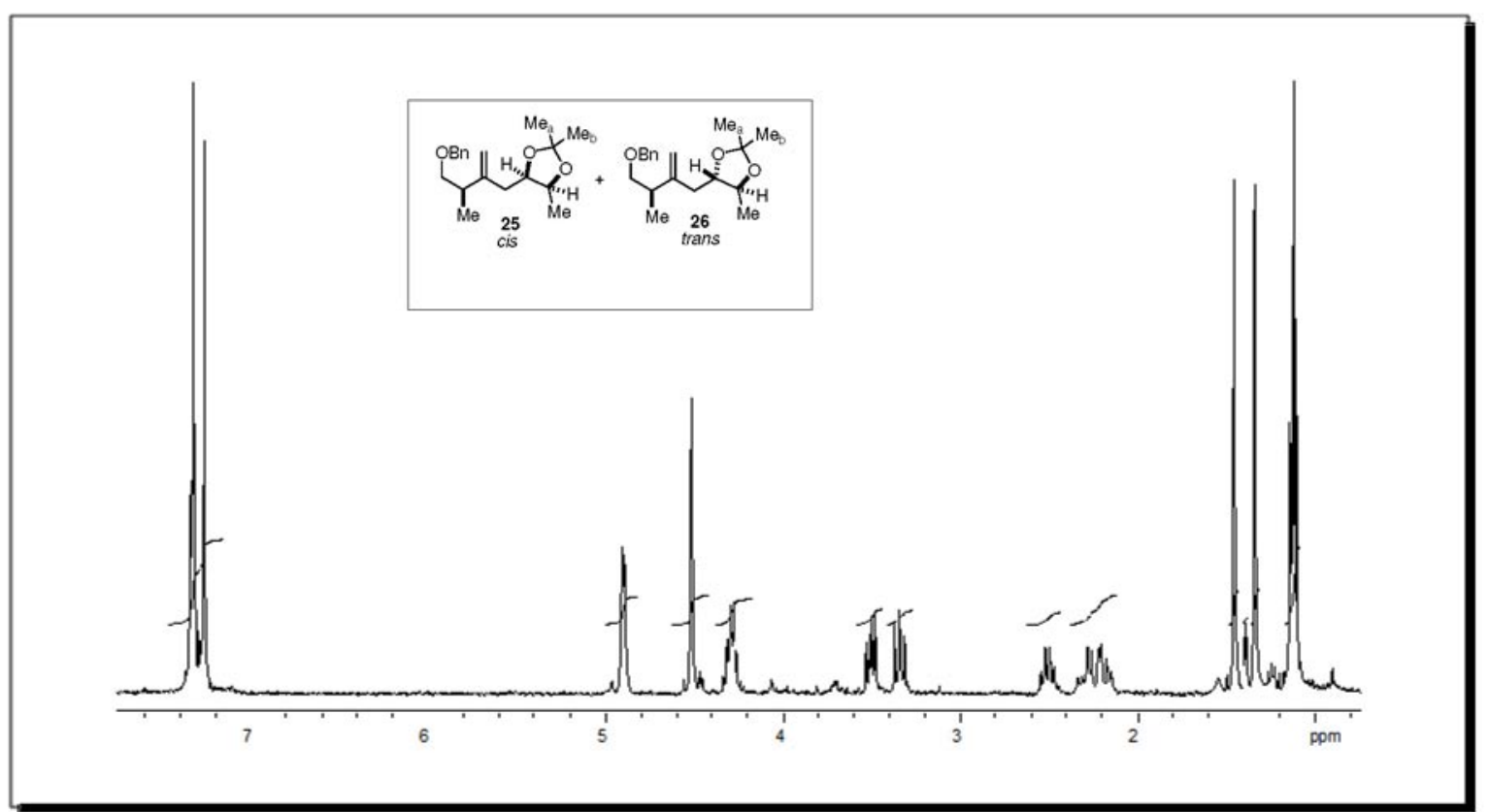

Figure 37S. ${ }^{1} \mathrm{H}$ NMR $\left(\mathrm{CDCl}_{3}, 300 \mathrm{MHz}\right)$ - (4R,5S)-4-((R)-4-(benzyloxy)-3-methyl-2-methylenebutyl)-2,2,5-trimethyl-1,3-dioxolane (25) and (4S,5S)-4$((R)$-4-(benzyloxy)-3-methyl-2-methylenebutyl)-2,2,5-trimethyl-1,3-dioxolane (26).

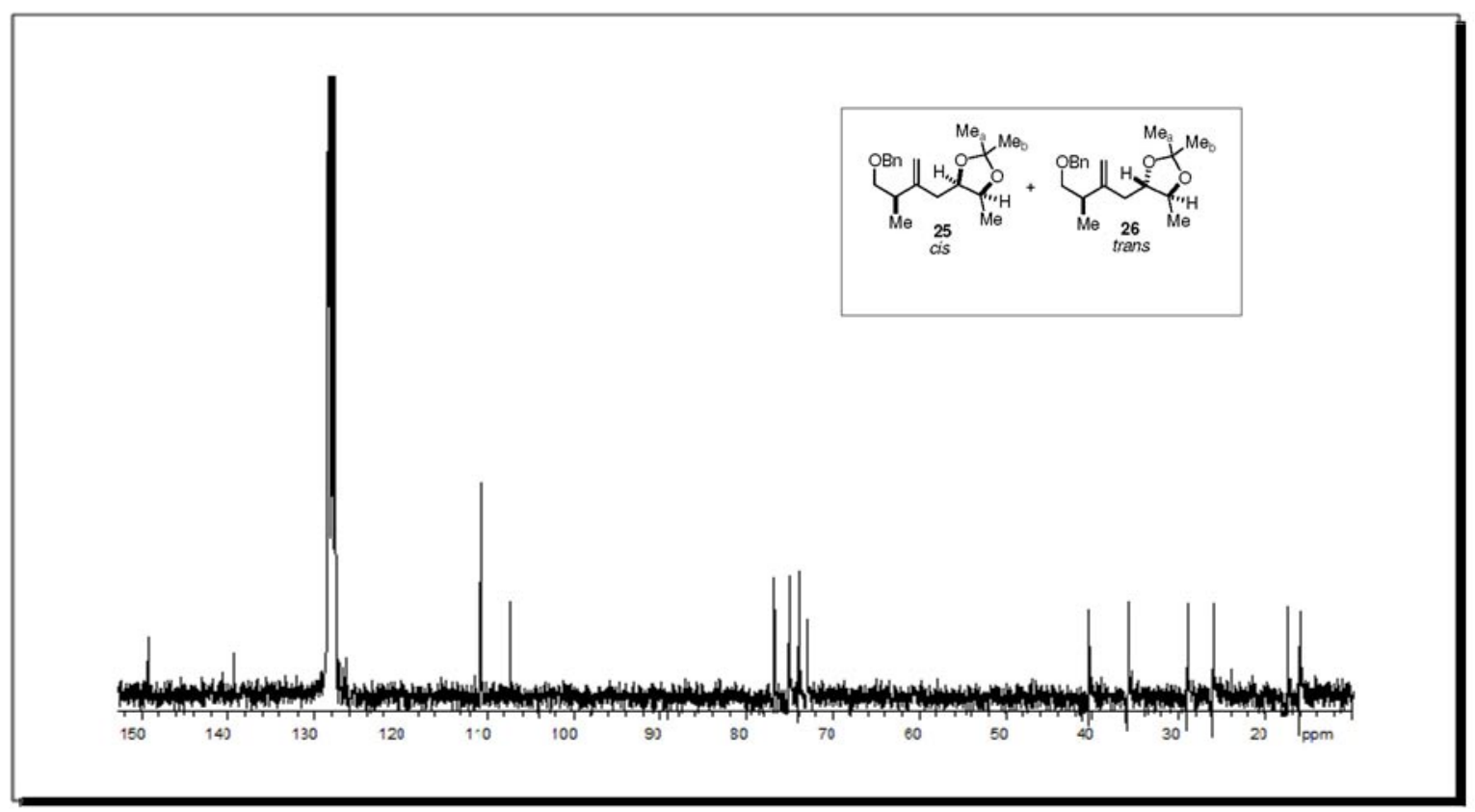

Figure 38S. ${ }^{13} \mathrm{C} \mathrm{NMR}\left(\mathrm{CDCl}_{3}, 75 \mathrm{MHz}\right)$ - (4R,5S)-4-((R)-4-(benzyloxy)-3-methyl-2-methylenebutyl)-2,2,5-trimethyl-1,3-dioxolane (25) and (4S,5S)-4$((R)-4$-(benzyloxy)-3-methyl-2-methylenebutyl)-2,2,5-trimethyl-1,3-dioxolane (26). 


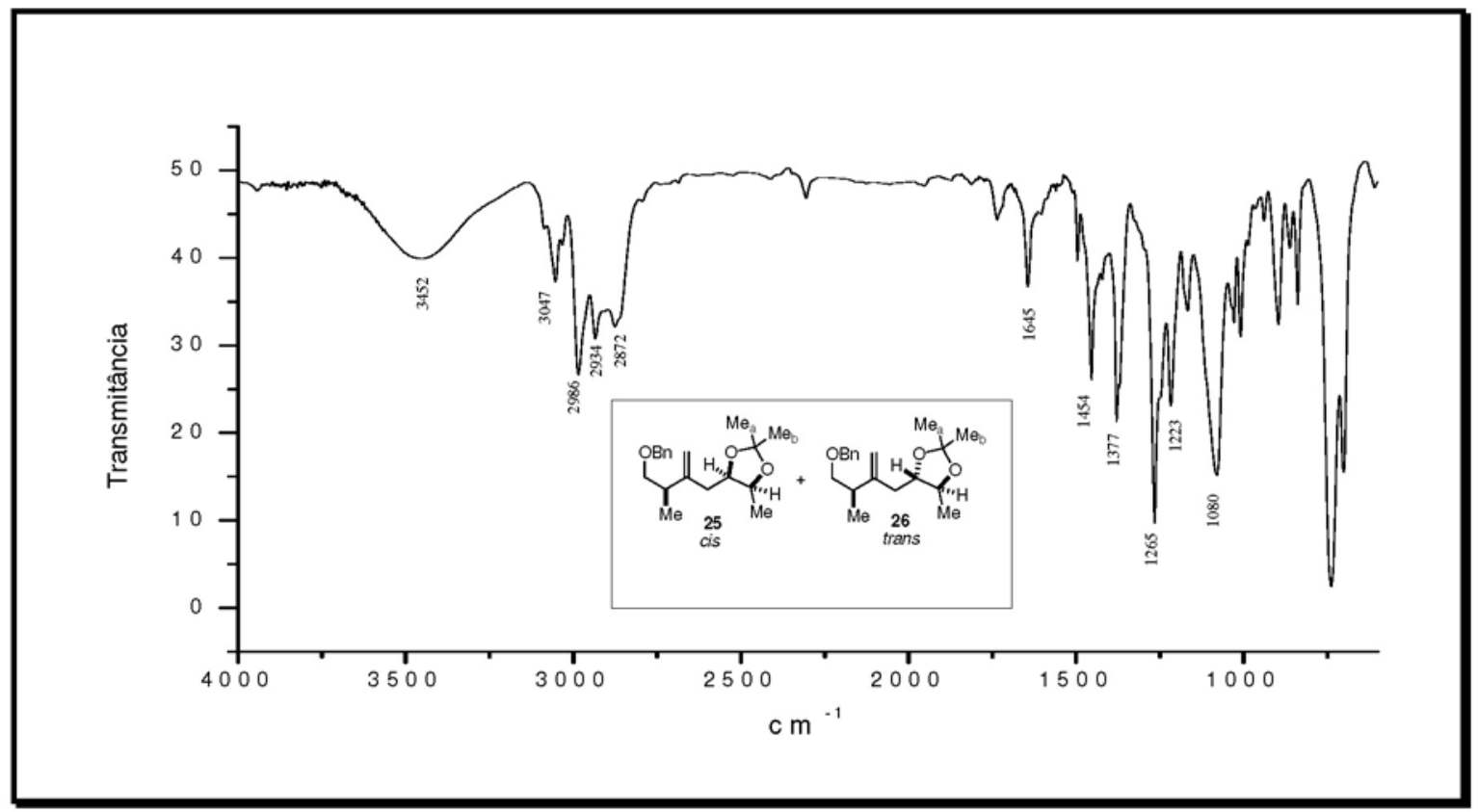

Figure 39S. IR (film) - (4R,5S)-4-((R)-4-(benzyloxy)-3-methyl-2-methylenebutyl)-2,2,5-trimethyl-1,3-dioxolane (25) and (4S,5S)-4-((R)-4-(benzyloxy)3-methyl-2-methylenebutyl)-2,2,5-trimethyl-1,3-dioxolane (26).

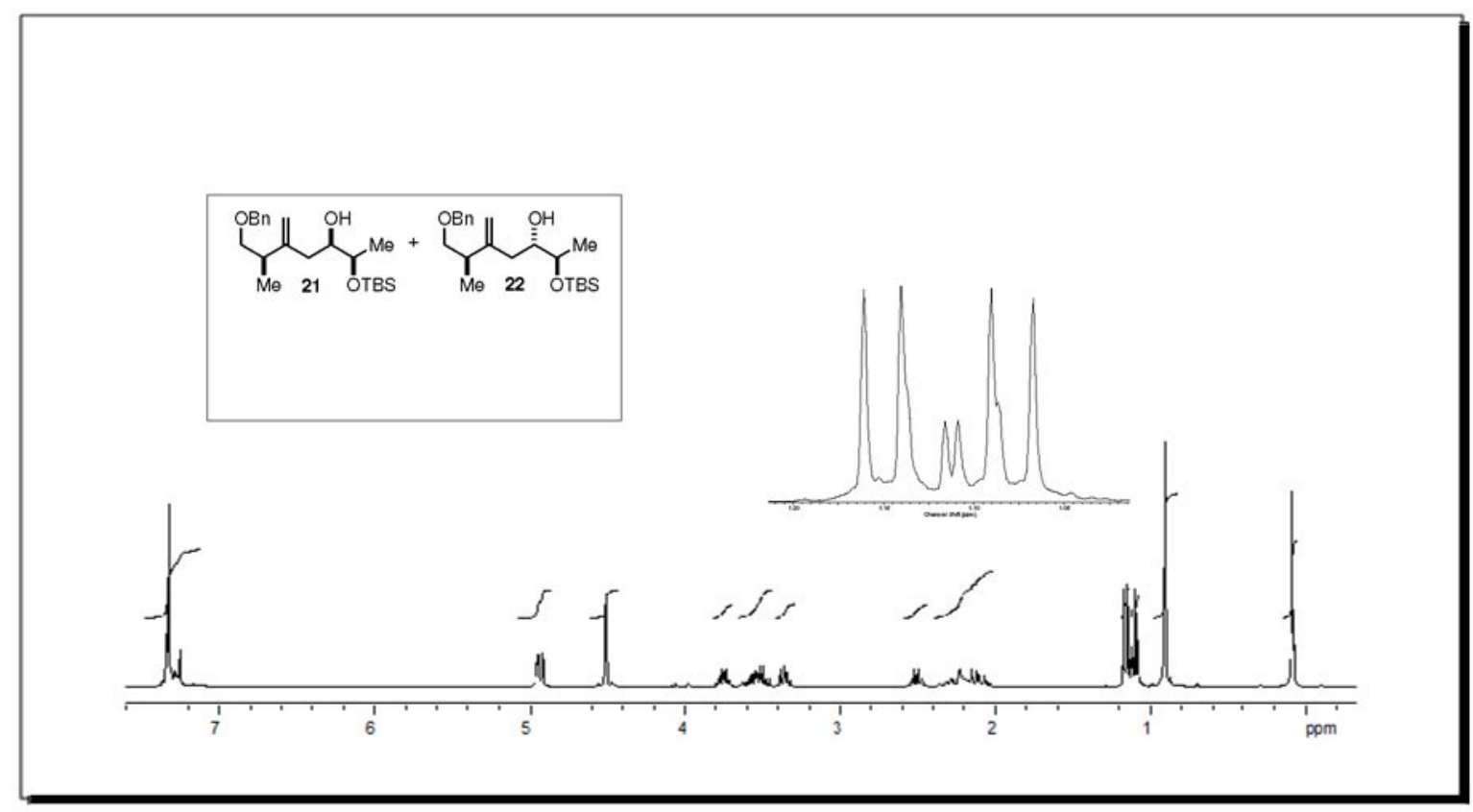

Figure 40S. ${ }^{1} \mathrm{H}$ NMR $\left(\mathrm{CDCl}_{3}, 300 \mathrm{MHz}\right)(2 R, 3 R, 6 R)$-7-(benzyloxy)-2-(tert-butyldimethylsilyloxy)-6-methyl-5-methyleneheptan-3-ol (21) and $(2 R, 3 S, 6 R)$-7-(benzyloxy)-2-(tert-butyldimethylsilyloxy)-6-methyl-5-methyleneheptan-3-ol (22). 


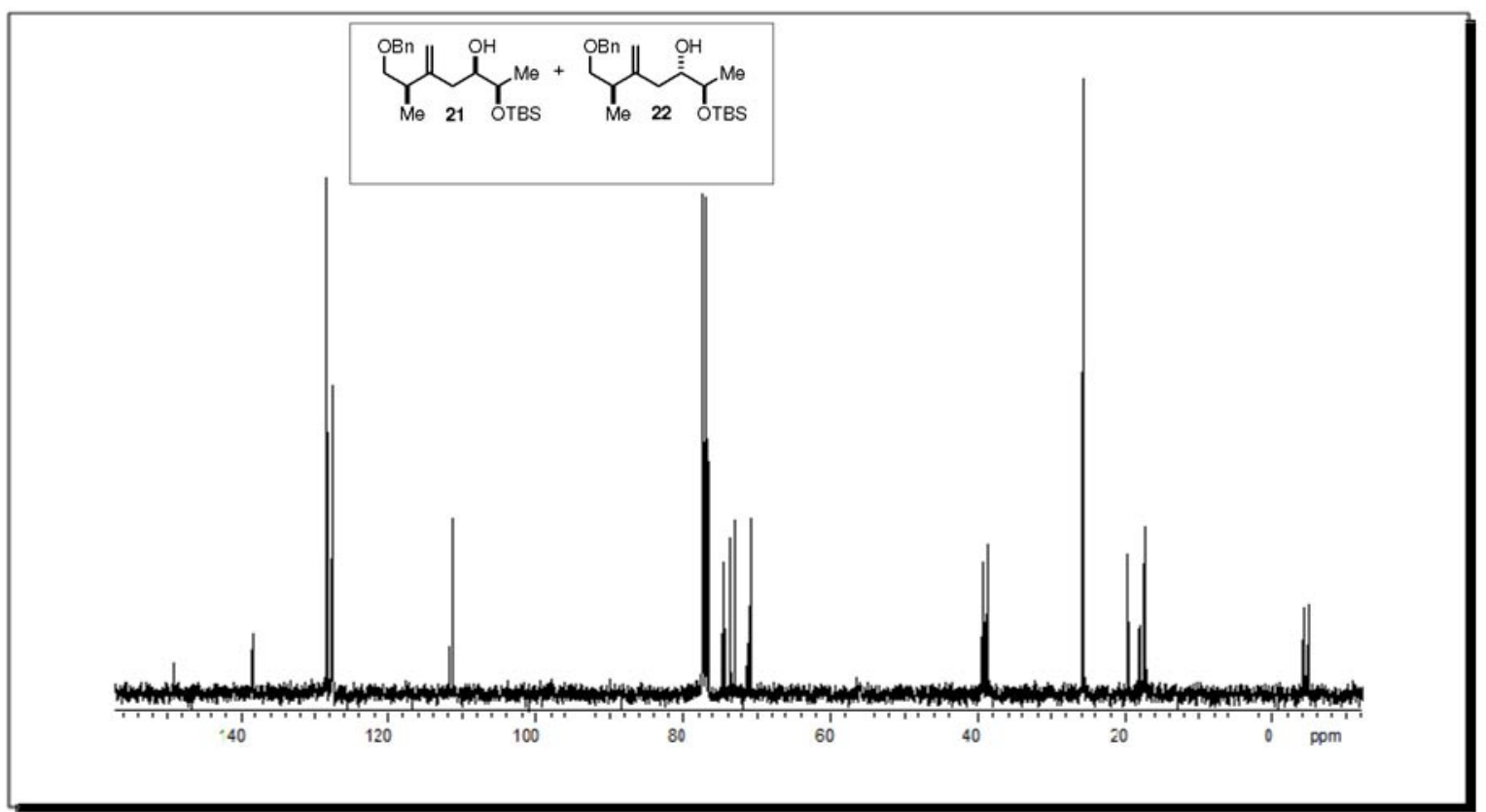

Figure 41S. ${ }^{13} \mathrm{C}$ NMR $\left(\mathrm{CDCl}_{3}, 75 \mathrm{MHz}\right)$ - (2R,3R,6R)-7-(benzyloxy)-2-(tert-butyldimethylsilyloxy)-6-methyl-5-methyleneheptan-3-ol (21) and $(2 R, 3 S, 6 R)$-7-(benzyloxy)-2-(tert-butyldimethylsilyloxy)-6-methyl-5-methyleneheptan-3-ol (22).

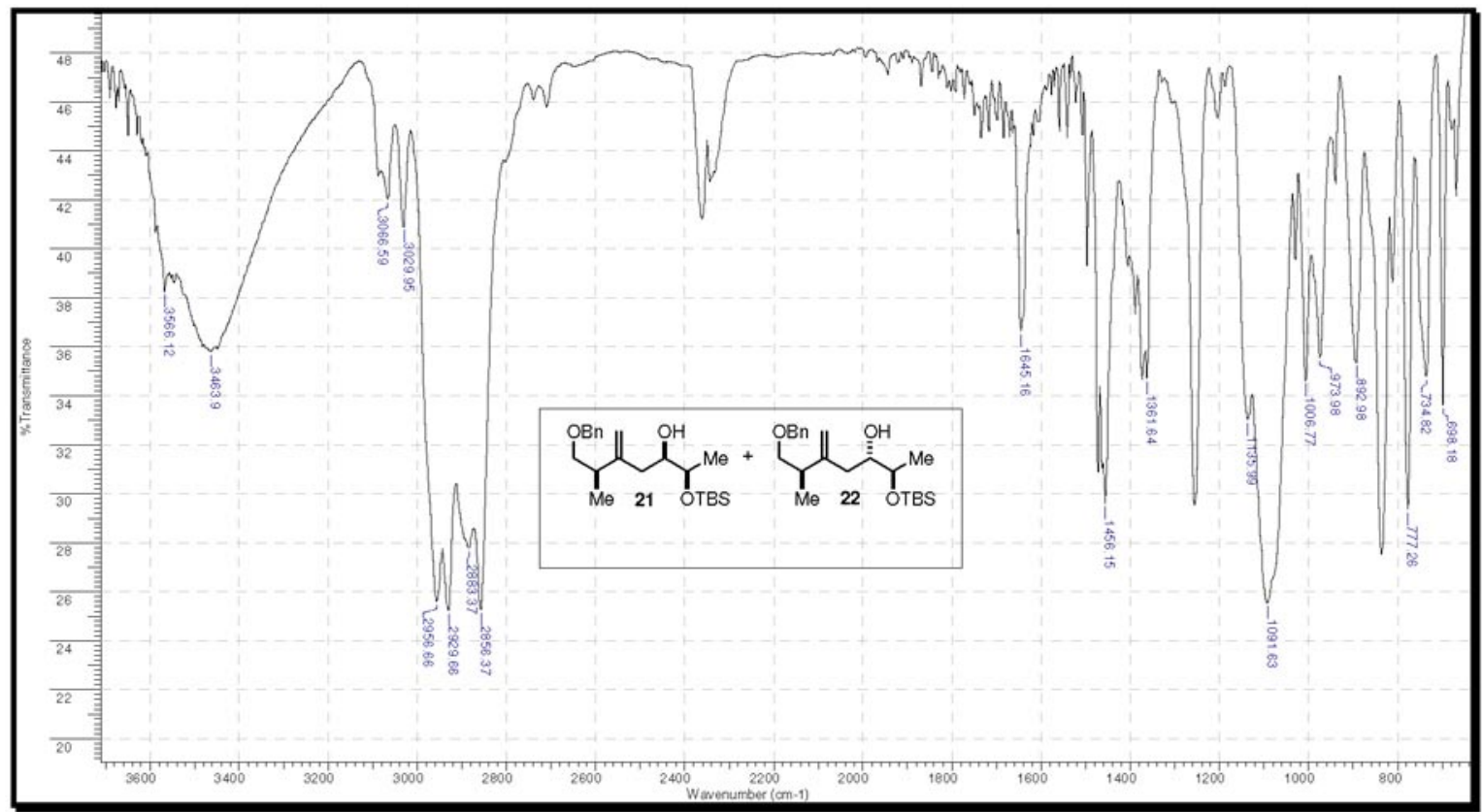

Figure 42S. IR (film) - (2R,3R,6R)-7-(benzyloxy)-2-(tert-butyldimethylsilyloxy)-6-methyl-5-methyleneheptan-3-ol (21) and ( $2 R, 3 S, 6 R)$-7-(benzyloxy)2-(tert-butyldimethylsilyloxy)-6-methyl-5-methyleneheptan-3-ol (22). 


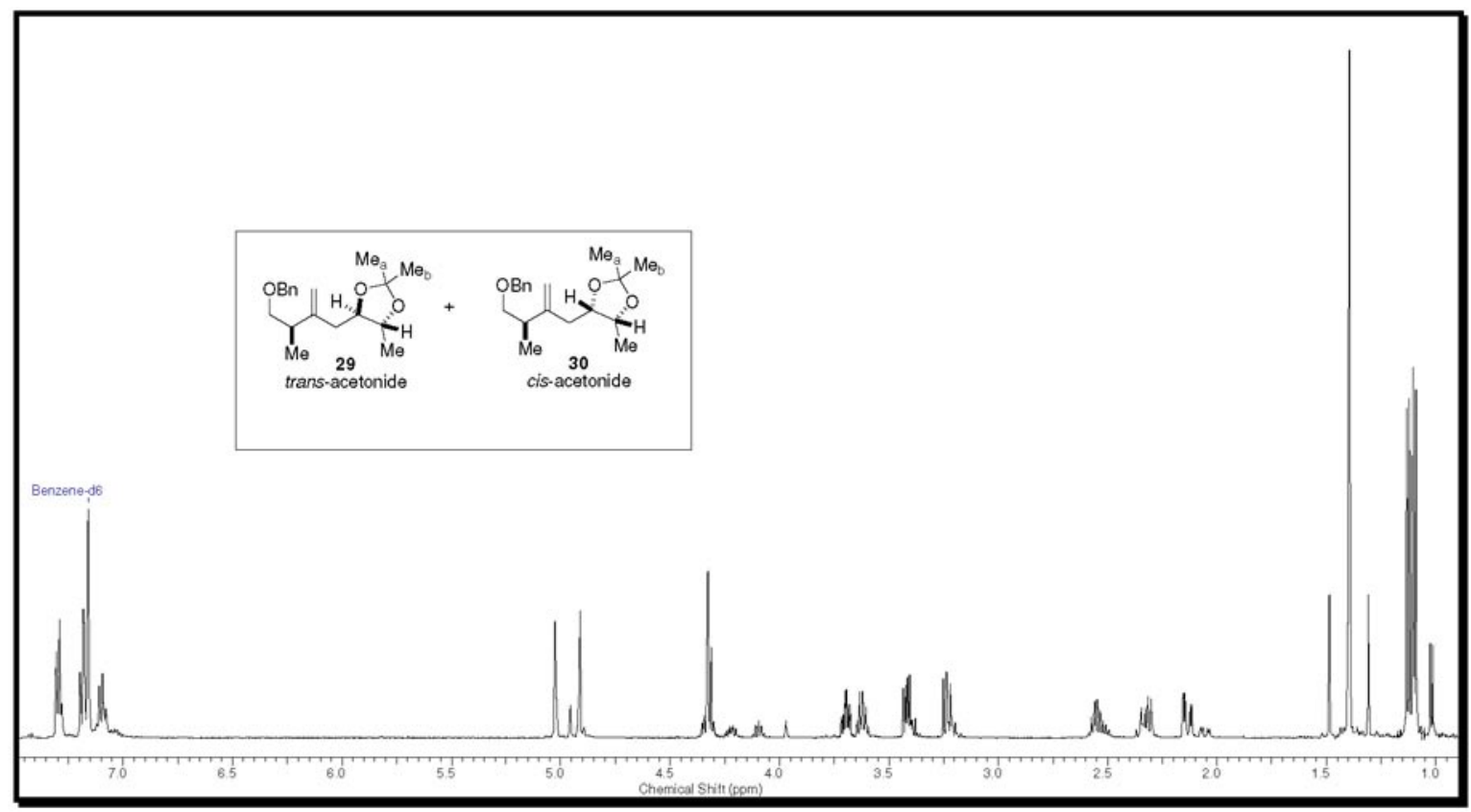

Figure 43S. ${ }^{1} \mathrm{H}$ NMR $\left(\mathrm{C}_{6} \mathrm{D}_{6}, 500 \mathrm{MHz}\right)$ - (4R,5R)-4-((R)-4-(benzyloxy)-3-methyl-2-methylenebutyl)-2,2,5-trimethyl-1,3-dioxolane (29) and (4S,5R)-4$((R)$-4-(benzyloxy)-3-methyl-2-methylenebutyl)-2,2,5-trimethyl-1,3-dioxolane (30).

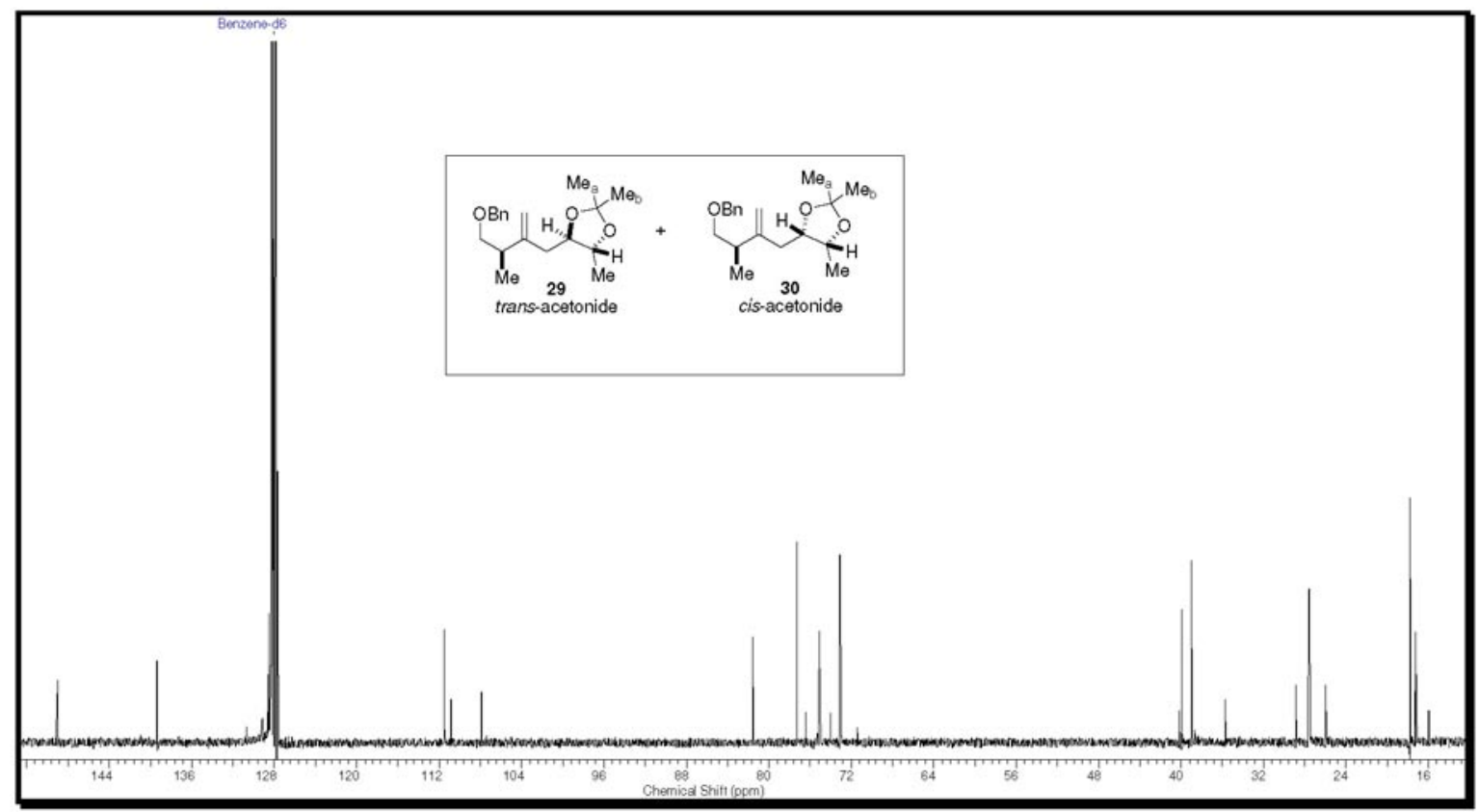

Figure 44S. ${ }^{13} \mathrm{C} \mathrm{NMR}\left(\mathrm{C}_{6} \mathrm{D}_{6}, 125 \mathrm{MHz}\right)$ - (4R,5R)-4-((R)-4-(benzyloxy)-3-methyl-2-methylenebutyl)-2,2,5-trimethyl-1,3-dioxolane (29) and (4S,5R)-4$((R)$-4-(benzyloxy)-3-methyl-2-methylenebutyl)-2,2,5-trimethyl-1,3-dioxolane (30). 
Vol. 00, No. 00, 2009

Dias et al.

S29

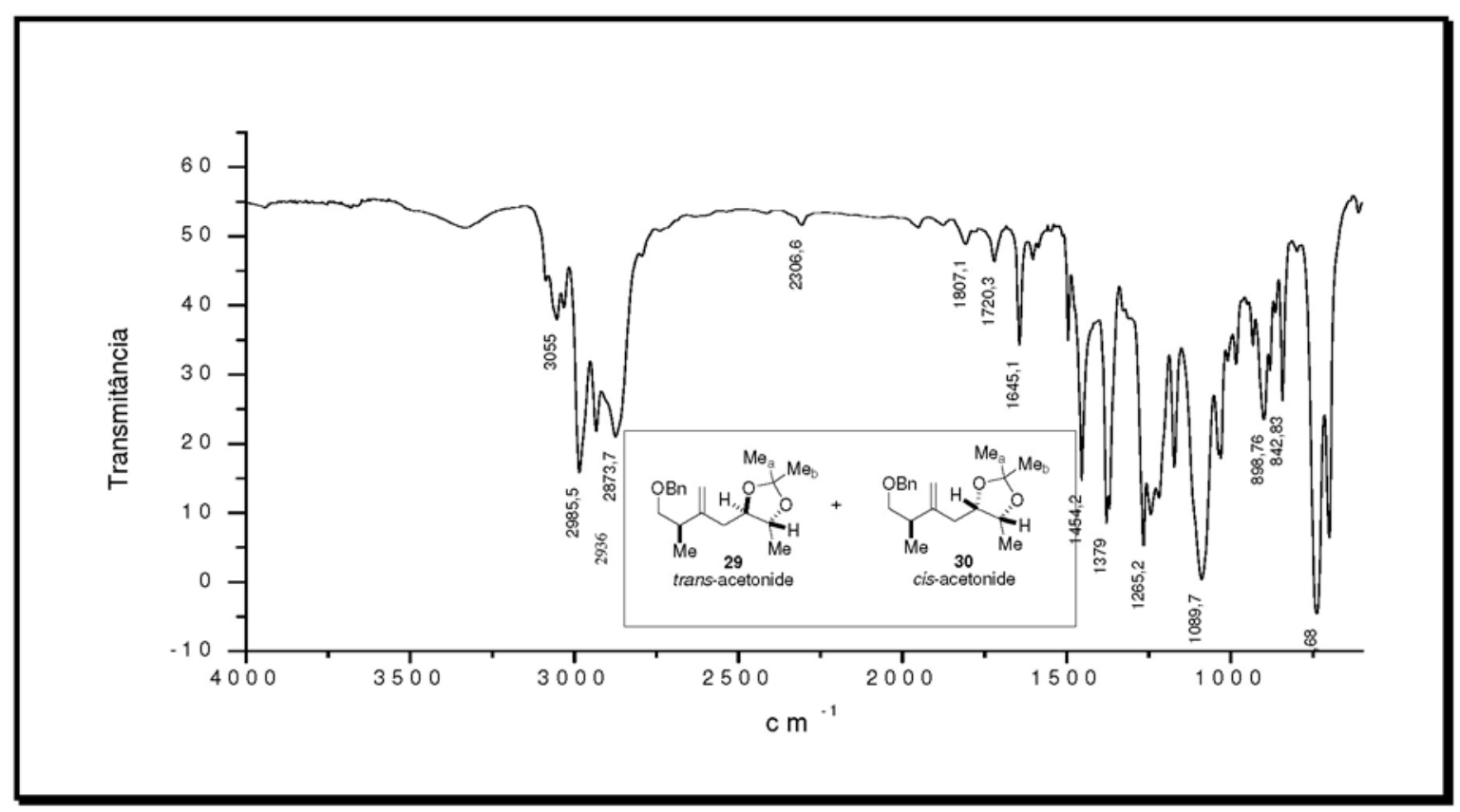

Figure 45S. IR (film) - (4R,5R)-4-((R)-4-(benzyloxy)-3-methyl-2-methylenebutyl)-2,2,5-trimethyl-1,3-dioxolane (29) and (4S,5R)-4-((R)-4(benzyloxy)-3-methyl-2-methylenebutyl)-2,2,5-trimethyl-1,3-dioxolane (30).

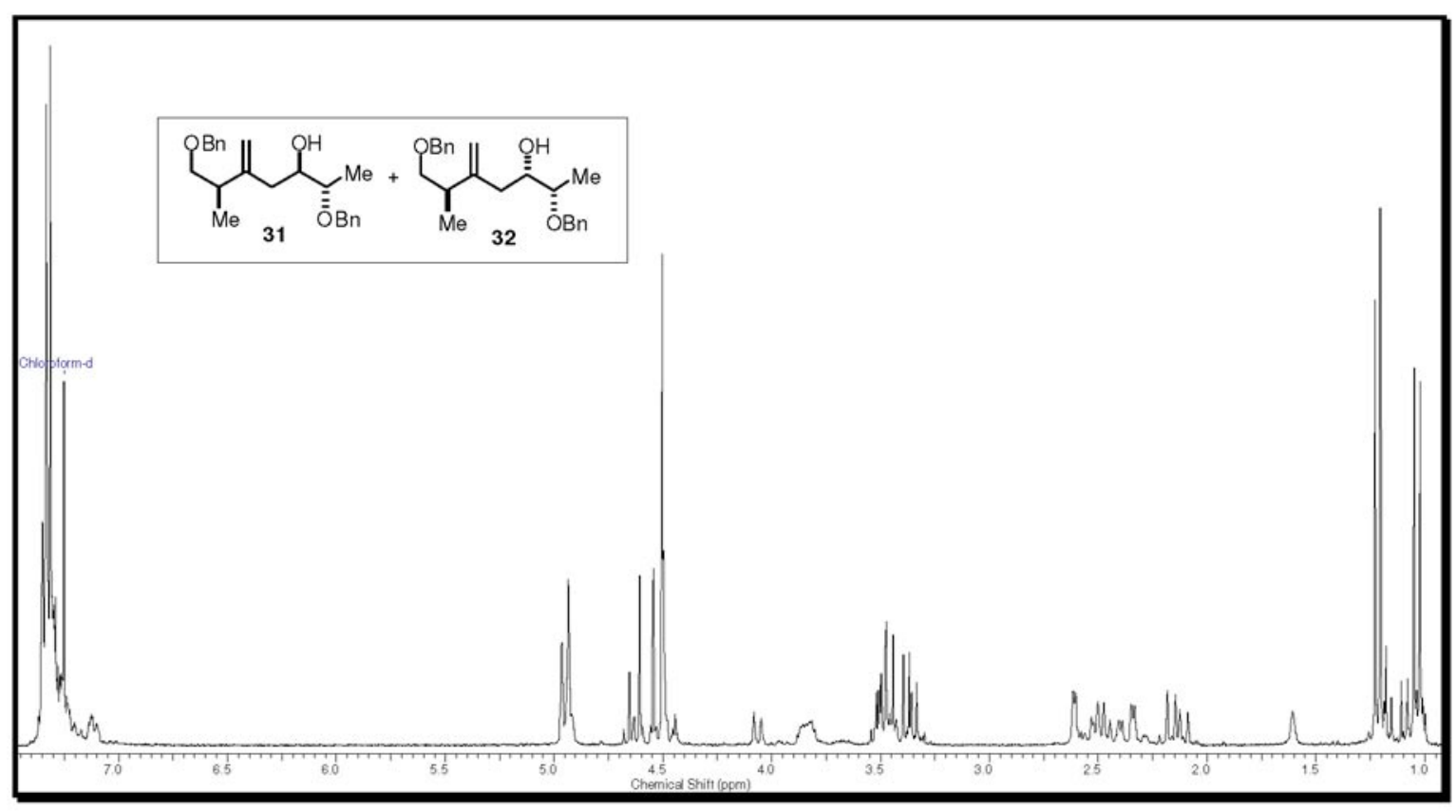

Figure 46S. ${ }^{1} \mathrm{H} \mathrm{NMR}\left(\mathrm{CDCl}_{3}, 250 \mathrm{MHz}\right)$ - (2S,3R,6R)-2,7-bis(benzyloxy)-6-methyl-5-methyleneheptan-3-ol (31) and (2S,3S,6R)-2,7-bis(benzyloxy)-6methyl-5-methyleneheptan-3-ol (32). 


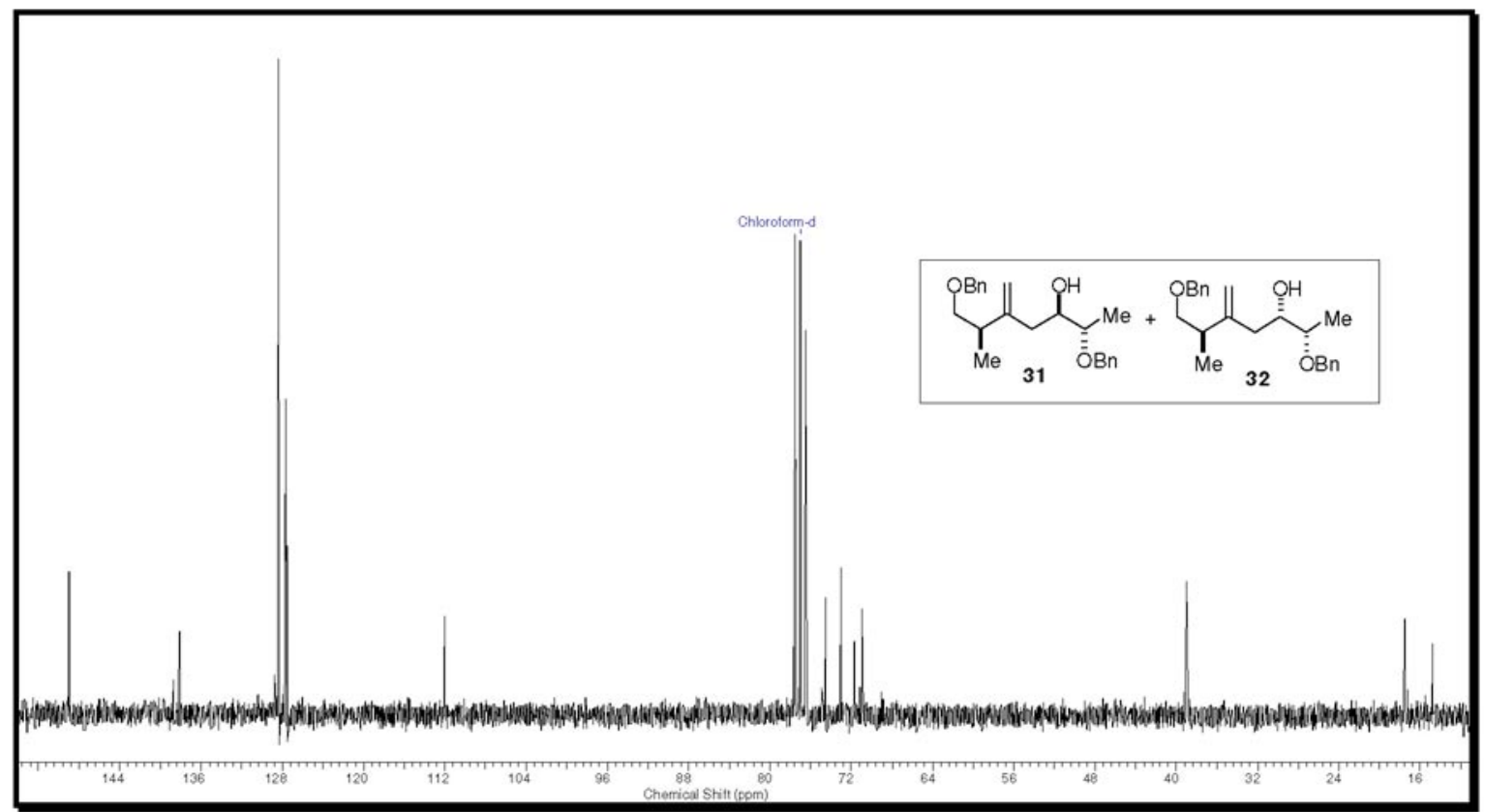

Figure 47S. ${ }^{13} \mathrm{C}$ NMR $\left(\mathrm{CDCl}_{3}, 63 \mathrm{MHz}\right)$ - (2S,3R,6R)-2,7-bis(benzyloxy)-6-methyl-5-methyleneheptan-3-ol (31) and (2S,3S,6R)-2,7-bis(benzyloxy)-6methyl-5-methyleneheptan-3-ol (32).

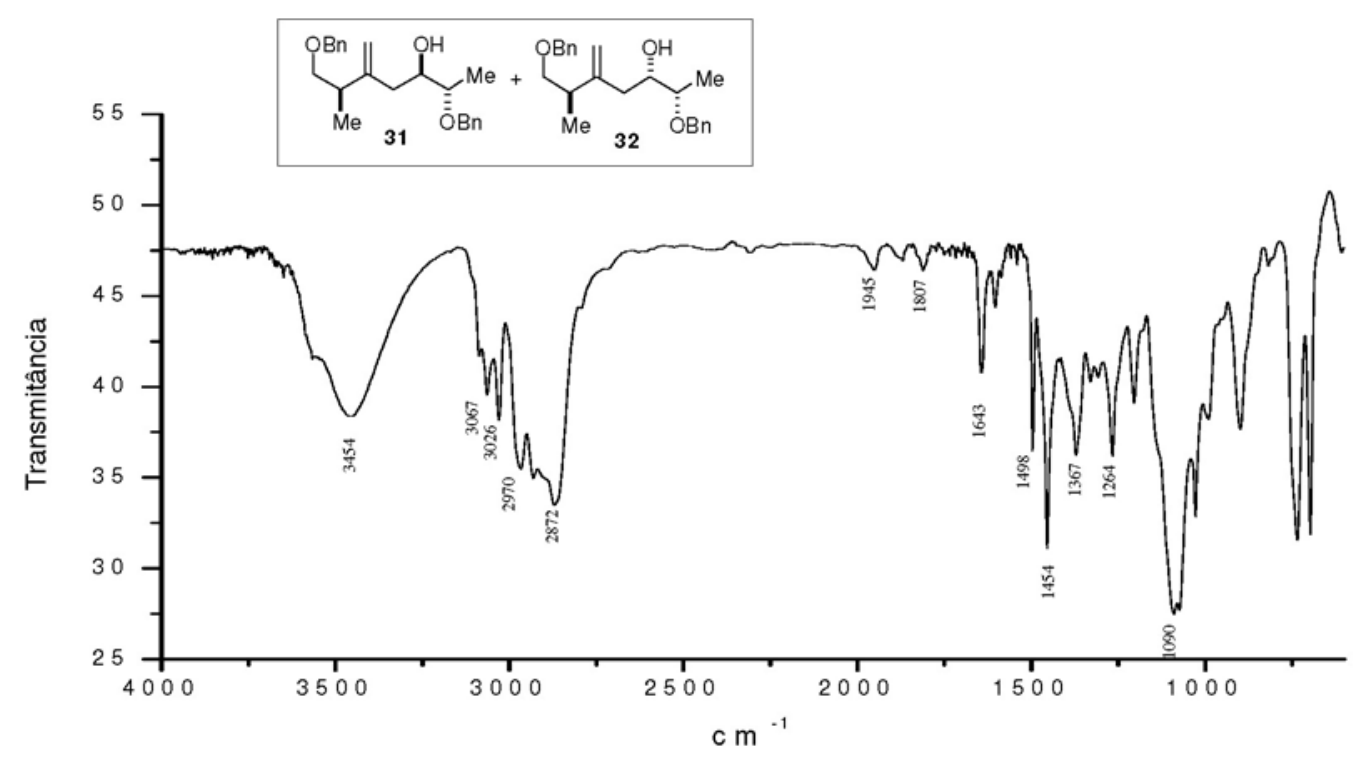

Figure 48S. IR (film) - (2S,3R,6R)-2,7-bis(benzyloxy)-6-methyl-5-methyleneheptan-3-ol (31) and (2S,3S,6R)-2,7-bis(benzyloxy)-6-methyl-5methyleneheptan-3-ol (32). 
Vol. 00, No. 00, 2009

Dias et al.

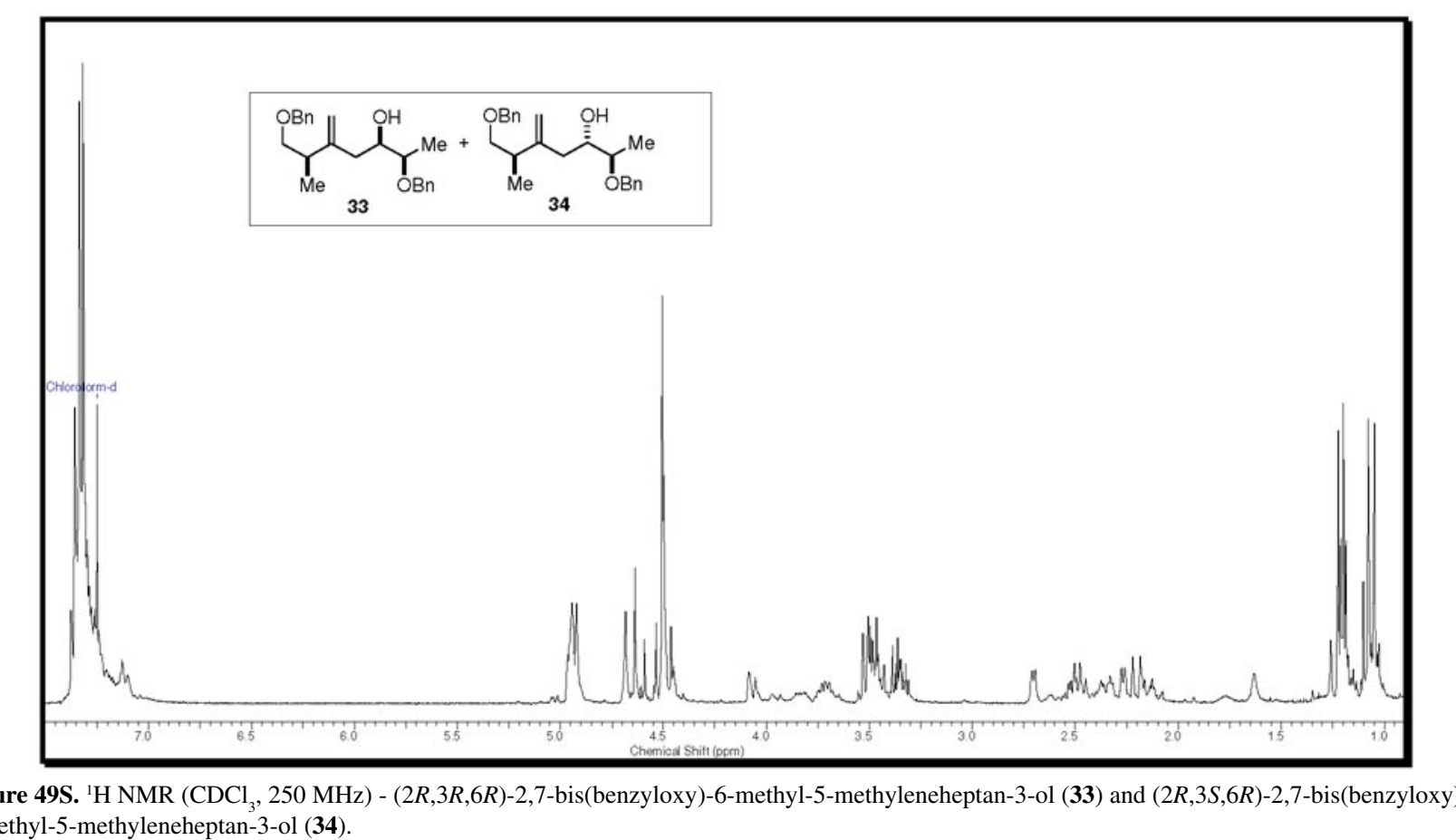

6-methyl-5-methyleneheptan-3-ol (34)

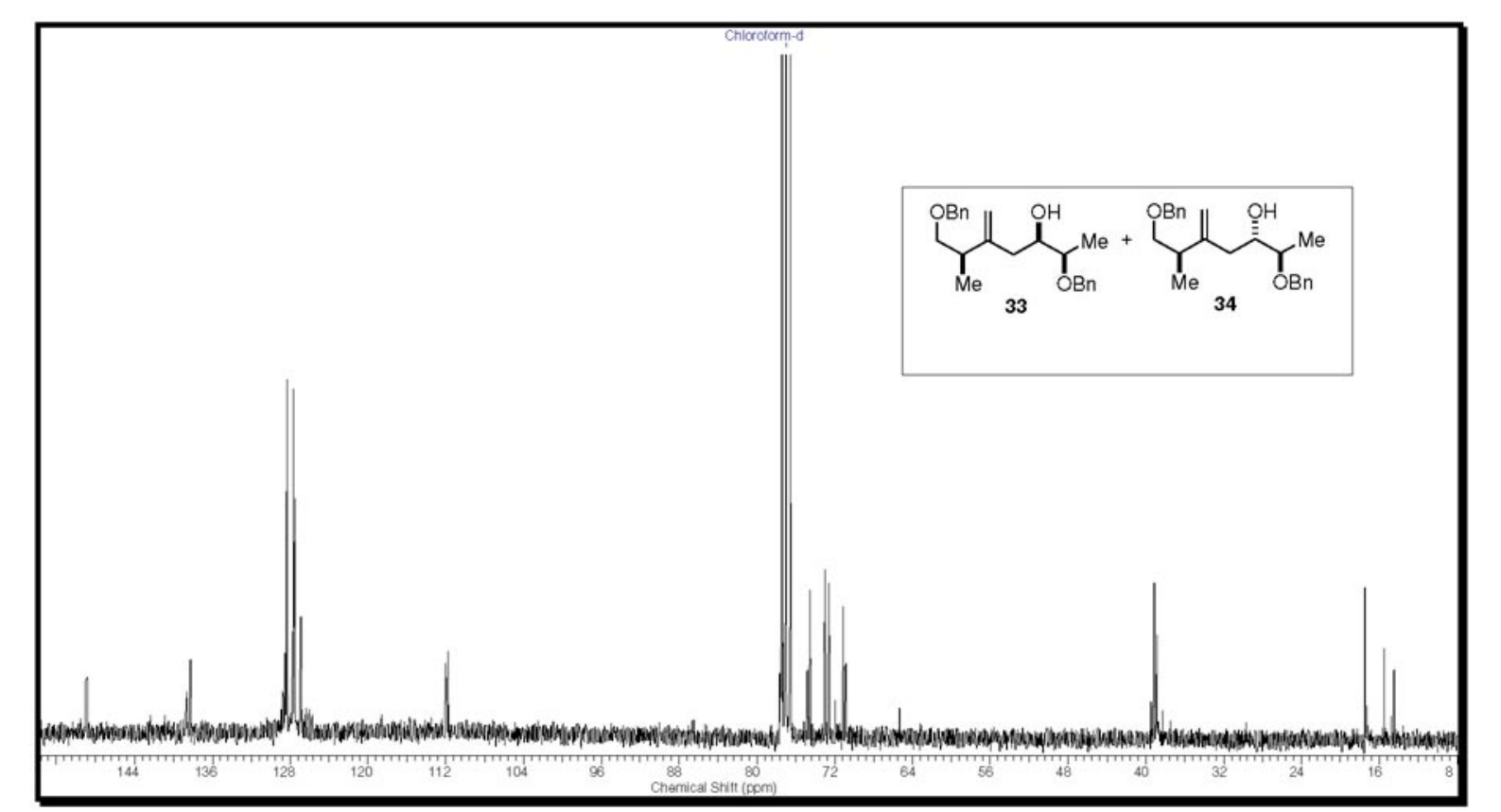

Figure 50S. $\left.{ }^{13} \mathrm{C} \mathrm{NMR} \mathrm{CDCl}_{3}, 75 \mathrm{MHz}\right)$
methyl-5-methyleneheptan-3-ol (34) 


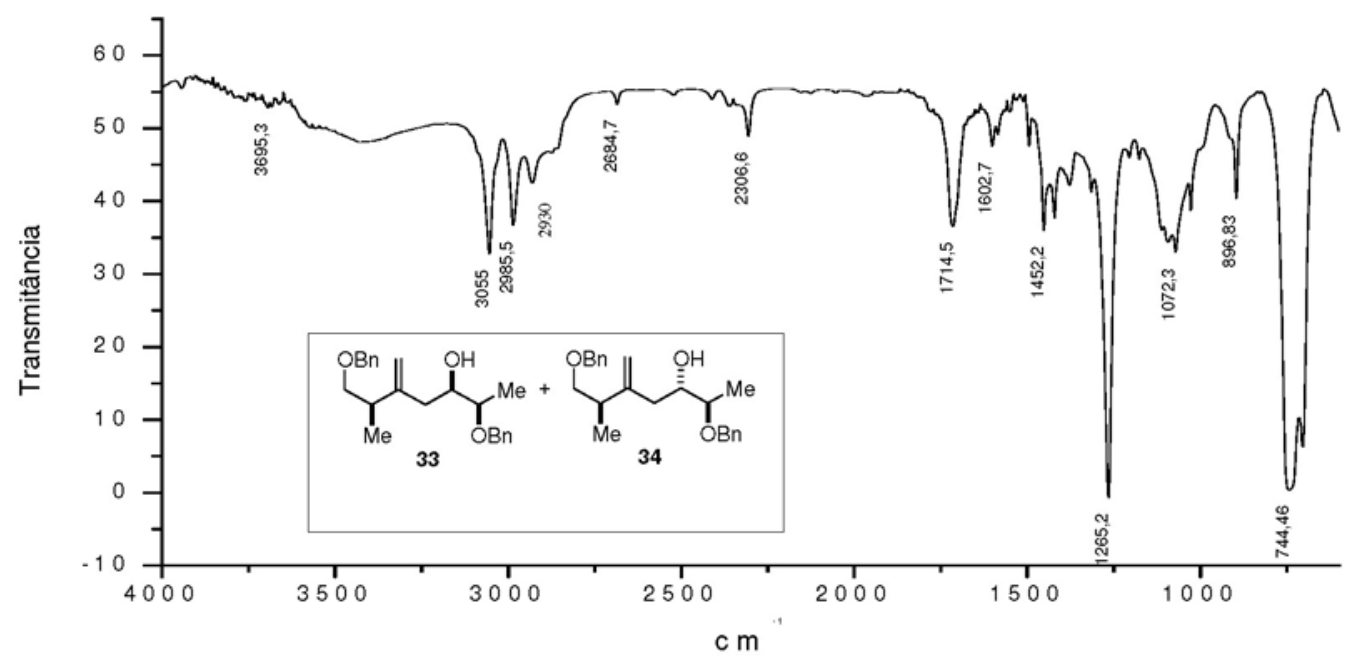

Figure 51S. IR (film) - (2R,3R,6R)-2,7-bis(benzyloxy)-6-methyl-5-methyleneheptan-3-ol (33) and (2R,3S,6R)-2,7-bis(benzyloxy)-6-methyl-5methyleneheptan-3-ol (34).

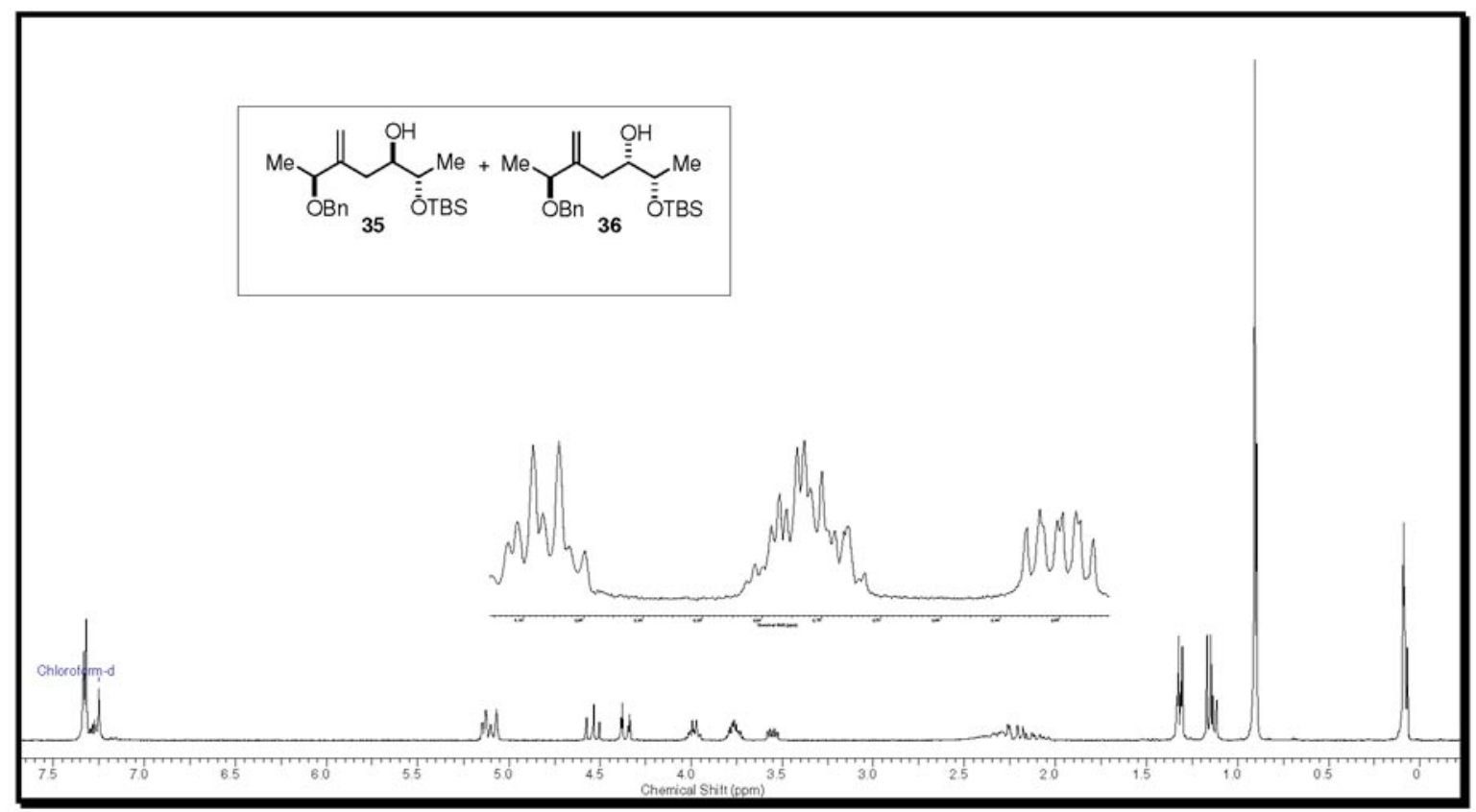

Figure 52S. ${ }^{1} \mathrm{H}$ NMR $\left(\mathrm{CDCl}_{3}, 300 \mathrm{MHz}\right)$ - (2S,3R,6S)-6-(benzyloxy)-2-(tert-butyldimethylsilyloxy)-5-methyleneheptan-3-ol (35) and (2S,3S,6S)-6(benzyloxy)-2-(tert-butyldimethylsilyloxy)-5-methyleneheptan-3-ol (36). 
Vol. 00, No. 00, 2009

Dias et al.

S33

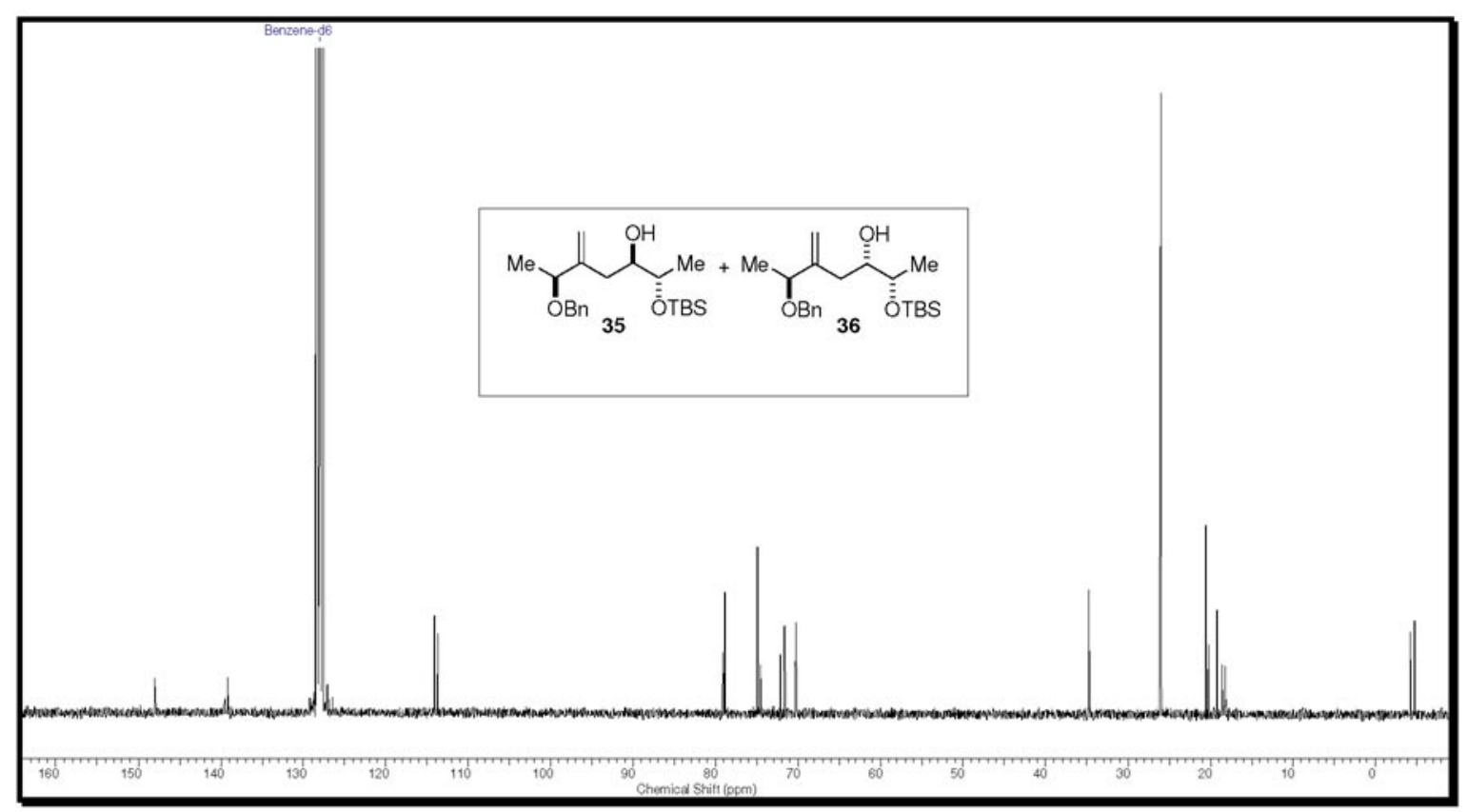

Figure 53S. ${ }^{13} \mathrm{C}$ NMR $\left(\mathrm{C}_{6} \mathrm{D}_{6}, 75 \mathrm{MHz}\right)$ - $(2 S, 3 R, 6 S)$-6-(benzyloxy)-2-(tert-butyldimethylsilyloxy)-5-methyleneheptan-3-ol (35) and (2S,3S,6S)-6(benzyloxy)-2-(tert-butyldimethylsilyloxy)-5-methyleneheptan-3-ol (36).

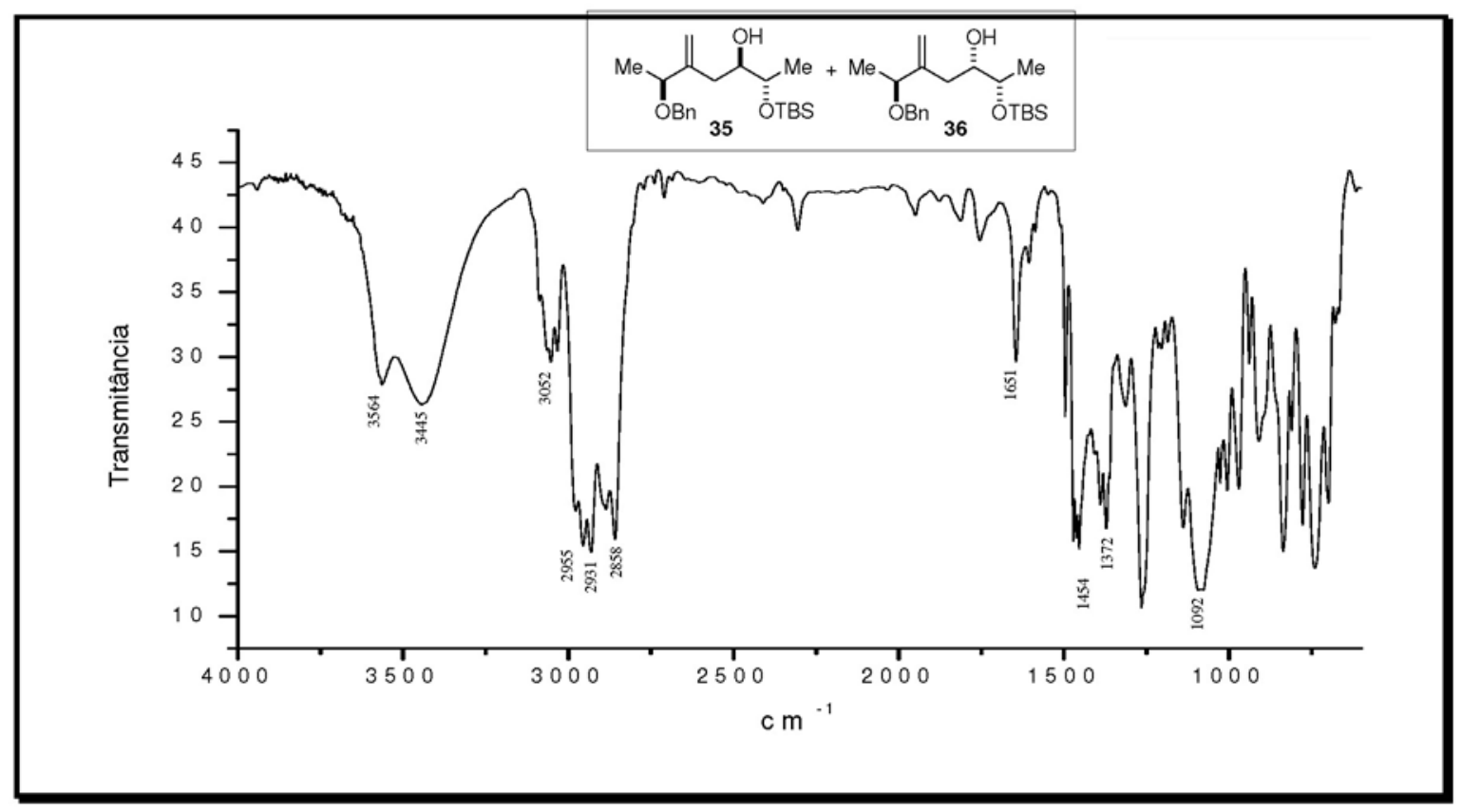

Figure 54S. IR (film) - (2S,3R,6S)-6-(benzyloxy)-2-(tert-butyldimethylsilyloxy)-5-methyleneheptan-3-ol (35) and (2S,3S,6S)-6-(benzyloxy)-2-(tertbutyldimethylsilyloxy)-5-methyleneheptan-3-ol (36). 


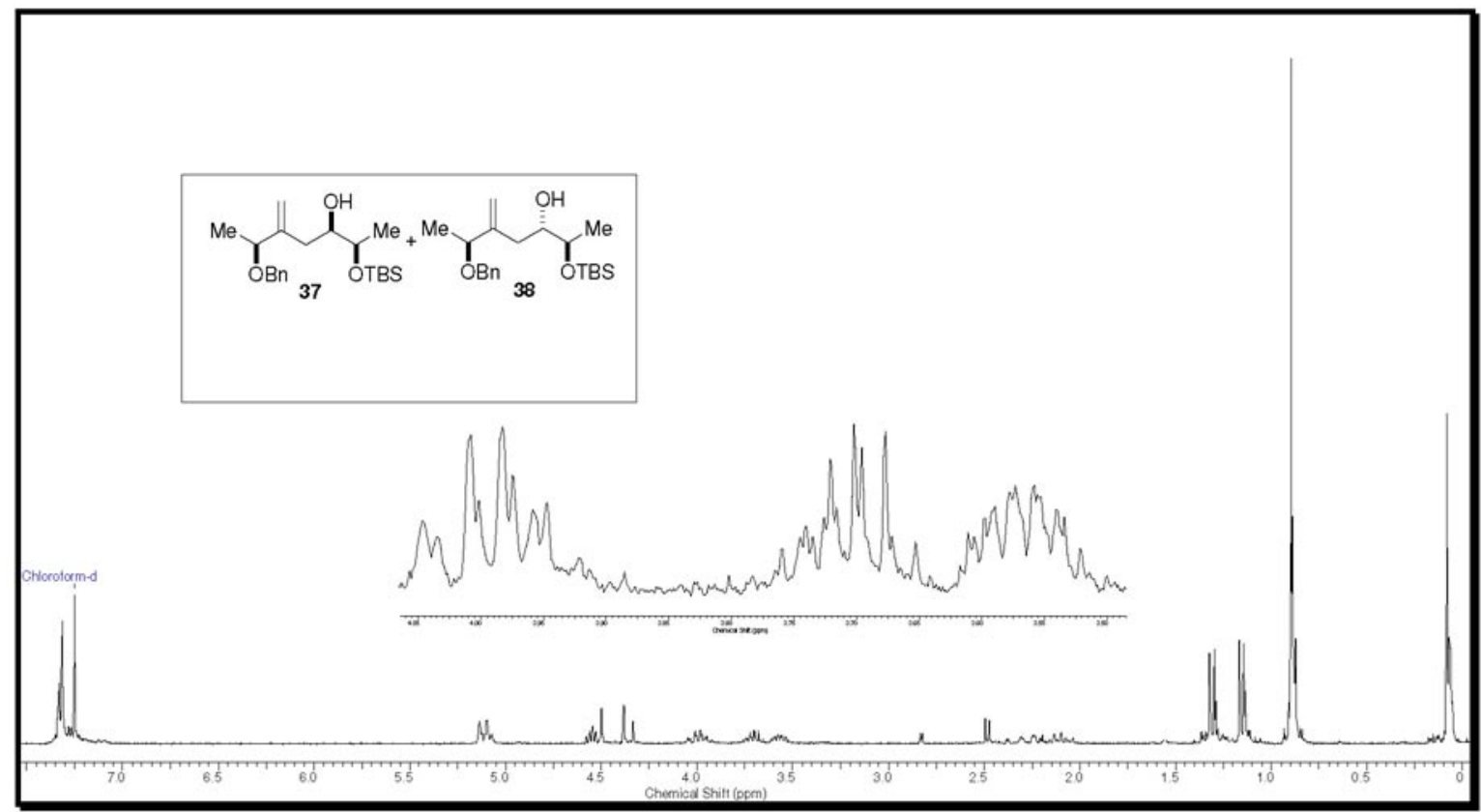

Figure 55S. ${ }^{1} \mathrm{H}$ NMR $\left(\mathrm{CDCl}_{3}, 250 \mathrm{MHz}\right)$ - $(2 R, 3 R, 6 S)$-6-(benzyloxy)-2-(tert-butyldimethylsilyloxy)-5-methyleneheptan-3-ol (37) and (2R,3S,6S)-6(benzyloxy)-2-(tert-butyldimethylsilyloxy)-5-methyleneheptan-3-ol (38).

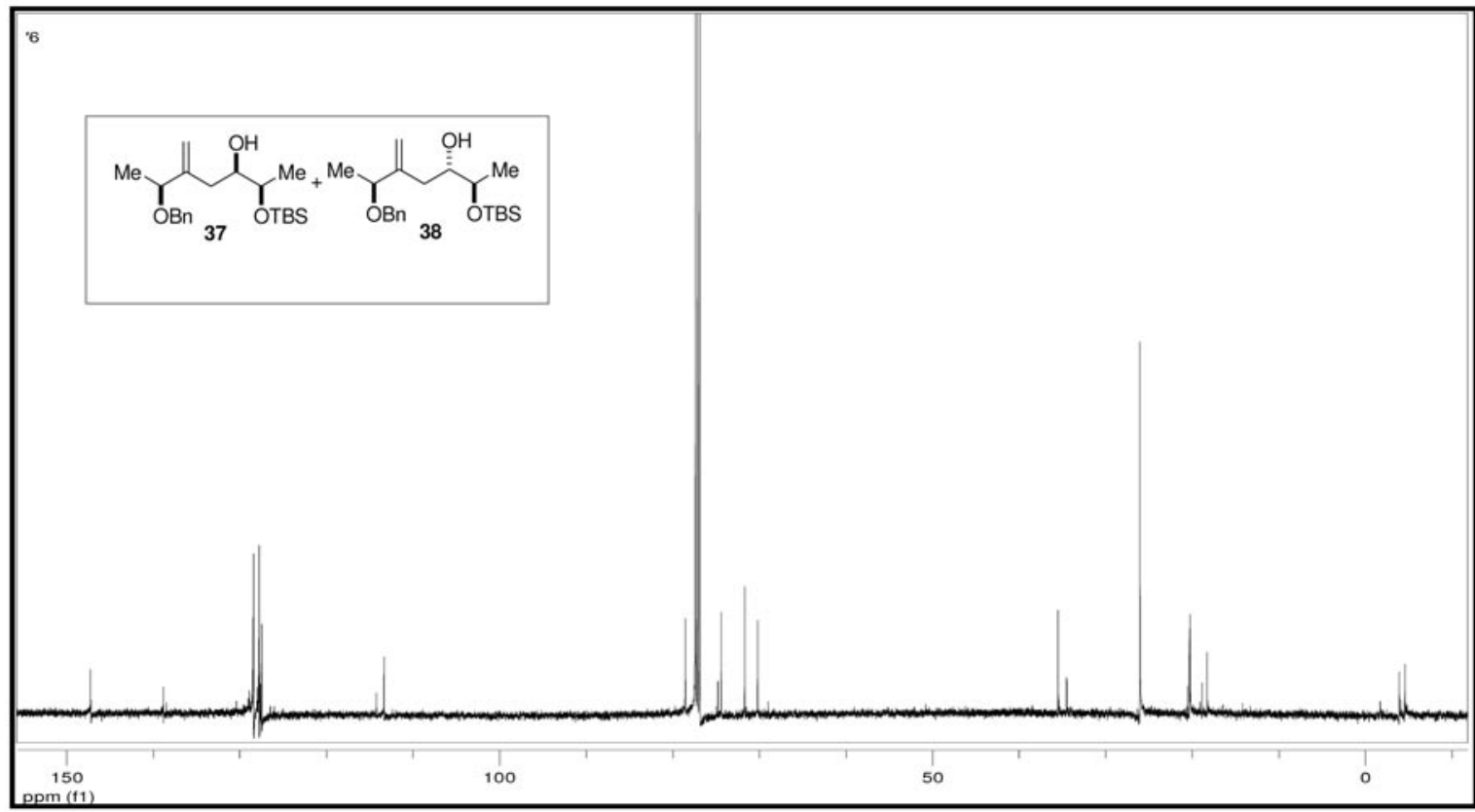

Figure 56S. ${ }^{13} \mathrm{C}$ NMR $\left(\mathrm{CDCl}_{3}, 63 \mathrm{MHz}\right)$ - (2R,3R,6S)-6-(benzyloxy)-2-(tert-butyldimethylsilyloxy)-5-methyleneheptan-3-ol (37) and (2R,3S,6S)-6(benzyloxy)-2-(tert-butyldimethylsilyloxy)-5-methyleneheptan-3-ol (38). 
Vol. 00, No. 00, 2009

Dias et al.

S35

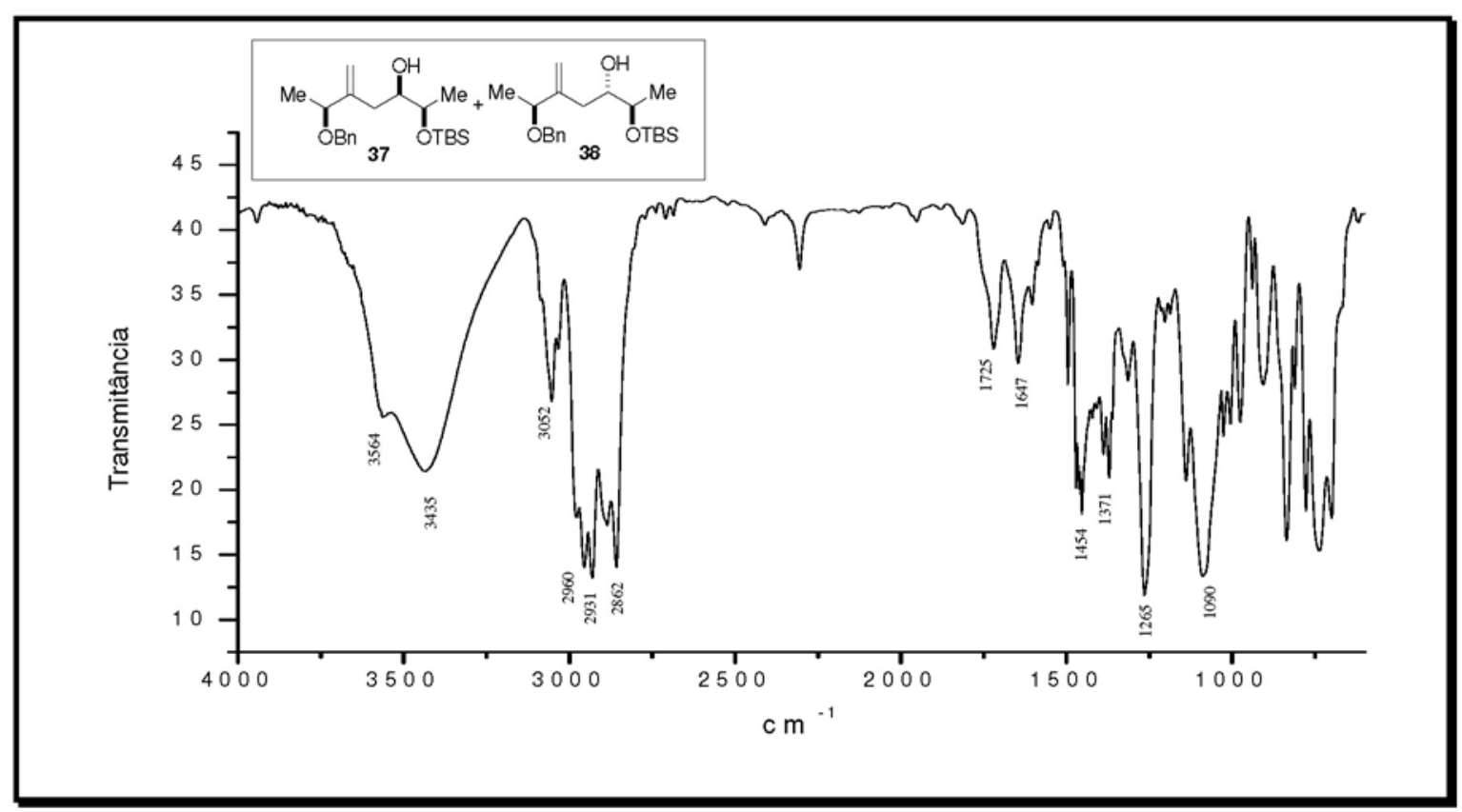

Figure 57S. IR (film) - (2R,3R,6S)-6-(benzyloxy)-2-(tert-butyldimethylsilyloxy)-5-methyleneheptan-3-ol (37) and (2R,3S,6S)-6-(benzyloxy)-2-(tertbutyldimethylsilyloxy)-5-methyleneheptan-3-ol (38).

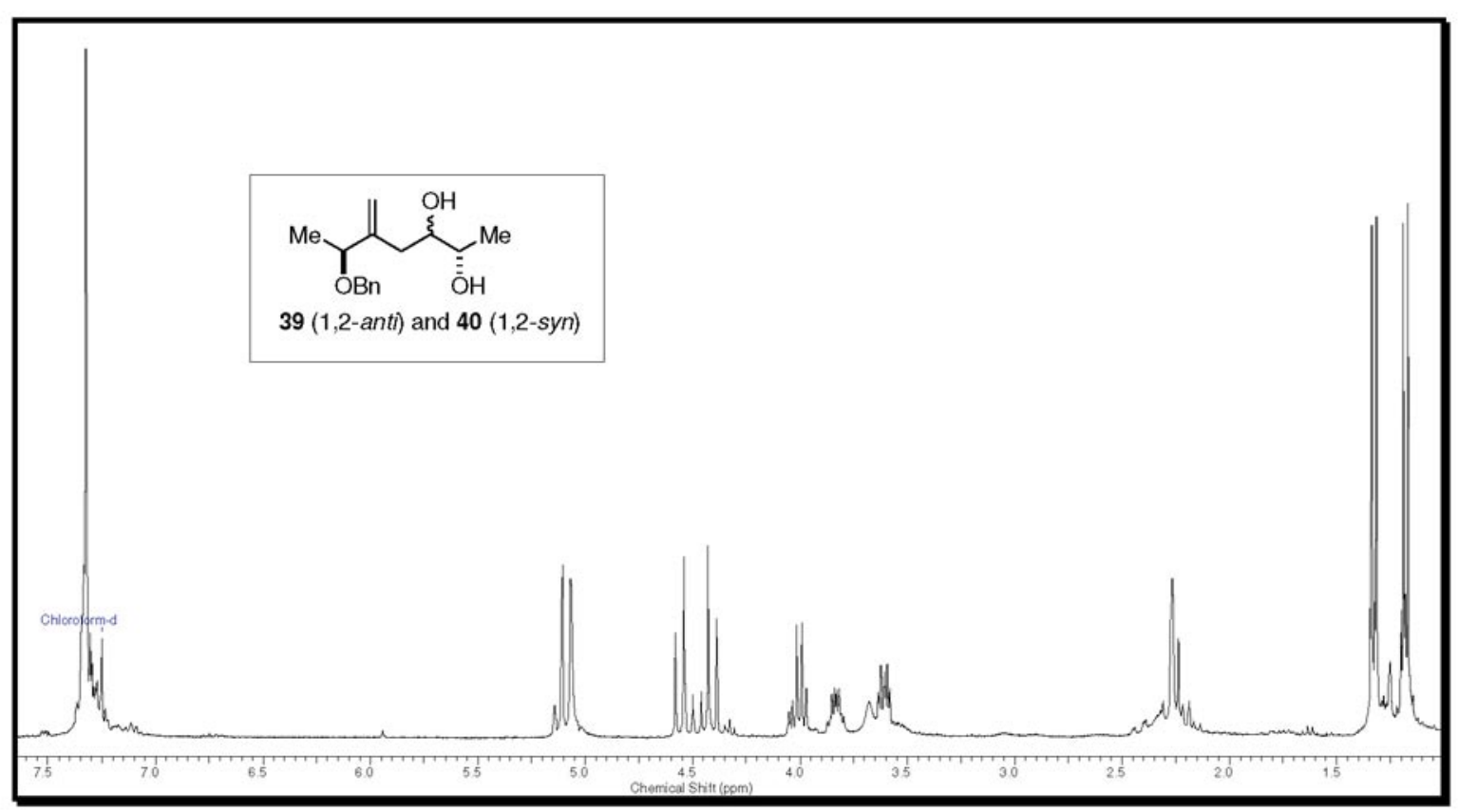

Figure 58S. ${ }^{1} \mathrm{H} \mathrm{NMR}\left(\mathrm{CDCl}_{3}, 300 \mathrm{MHz}\right)$ - (2S,6S)-6-(benzyloxy)-5-methyleneheptane-2,3-diol (39) and (40). 


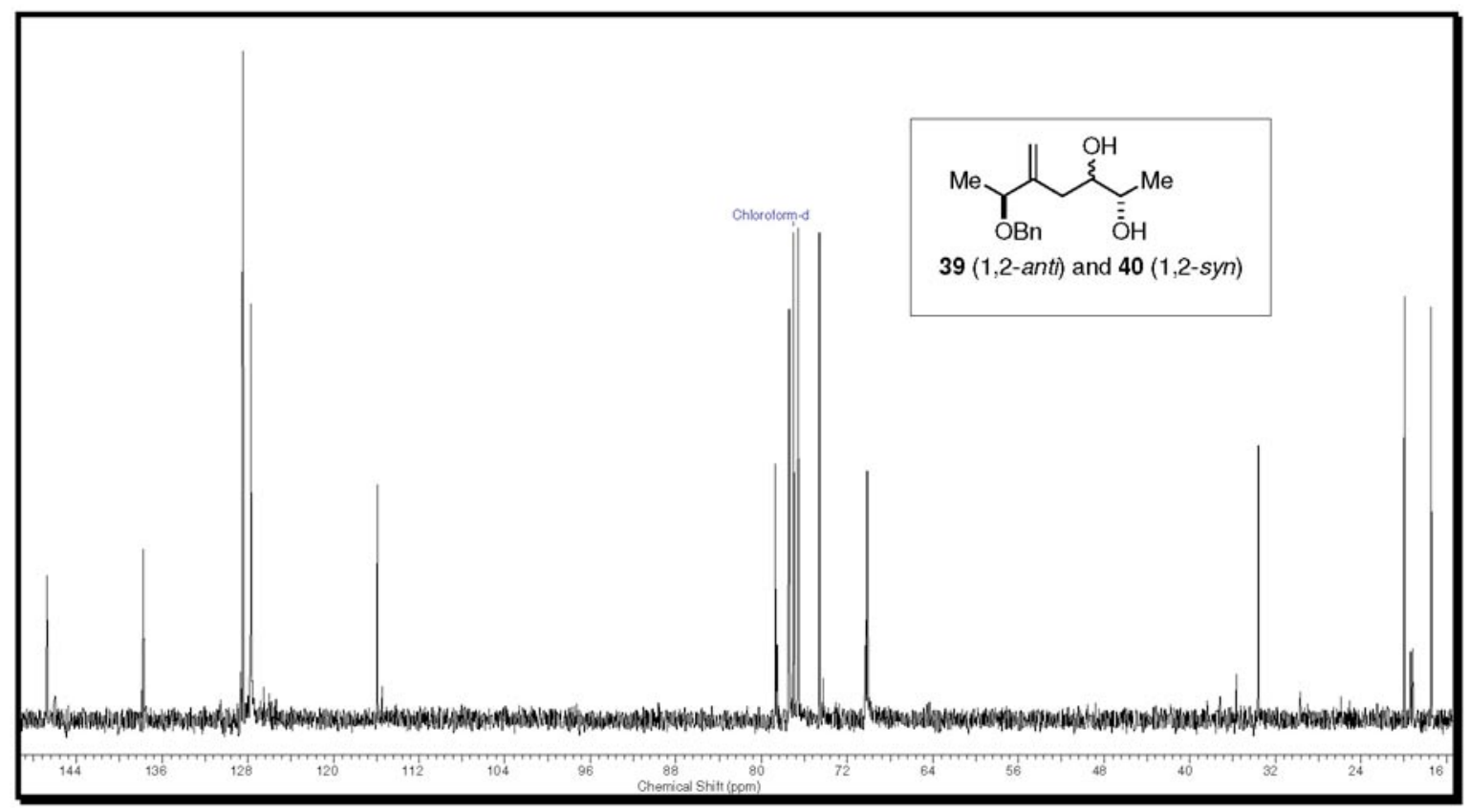

Figure 59S. ${ }^{13} \mathrm{C} \mathrm{NMR}\left(\mathrm{CDCl}_{3}, 75 \mathrm{MHz}\right)$ - (2S,6S)-6-(benzyloxy)-5-methyleneheptane-2,3-diol (39) and (40).

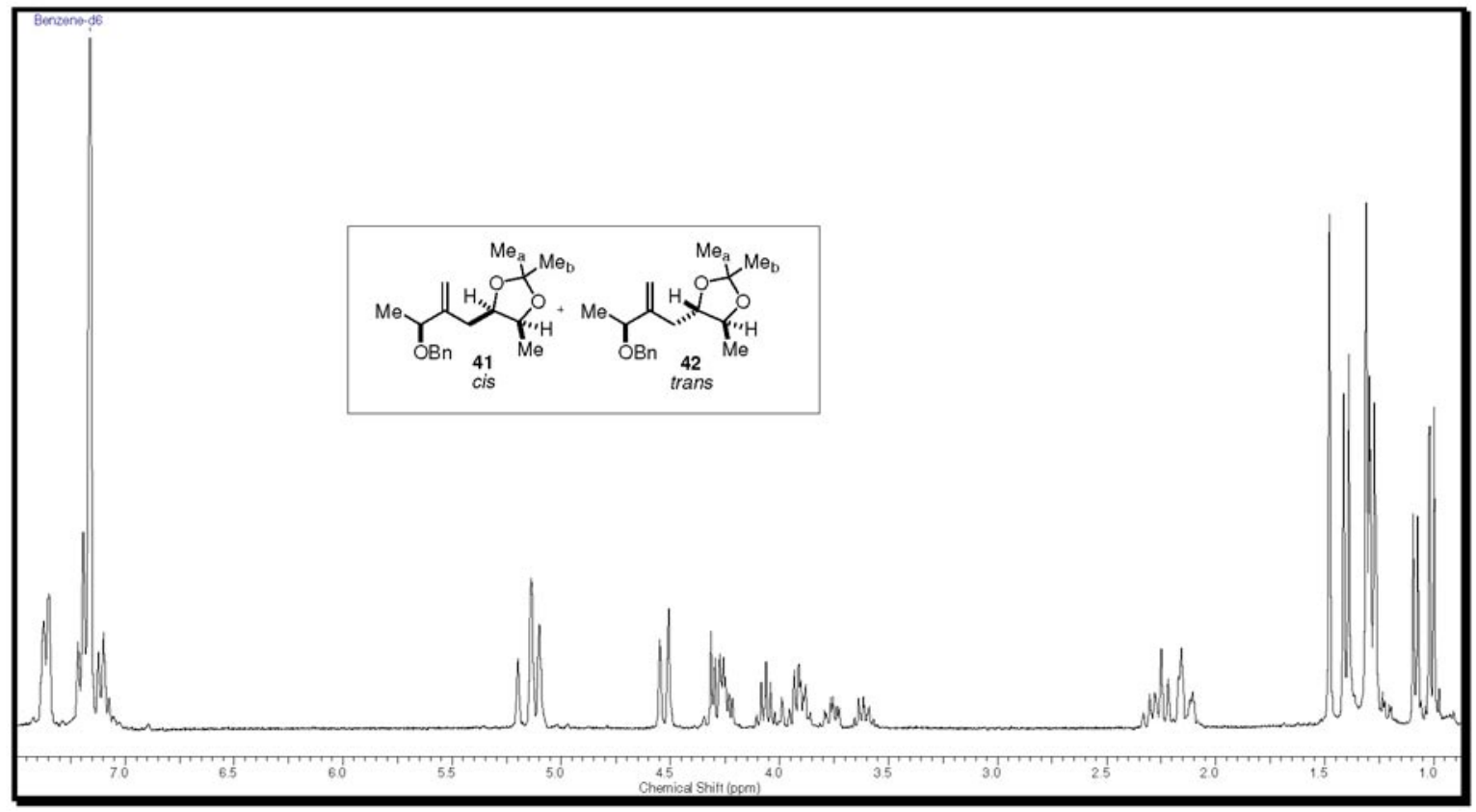

Figure 60S. ${ }^{1} \mathrm{H}$ NMR $\left(\mathrm{C}_{6} \mathrm{D}_{6}, 300 \mathrm{MHz}\right)$ - (4R,5S)-4-((S)-3-(benzyloxy)-2-methylenebutyl)-2,2,5-trimethyl-1,3-dioxolane (41) and (4S,5S)-4-((S)-3(benzyloxy)-2-methylenebutyl)-2,2,5-trimethyl-1,3-dioxolane (42). 


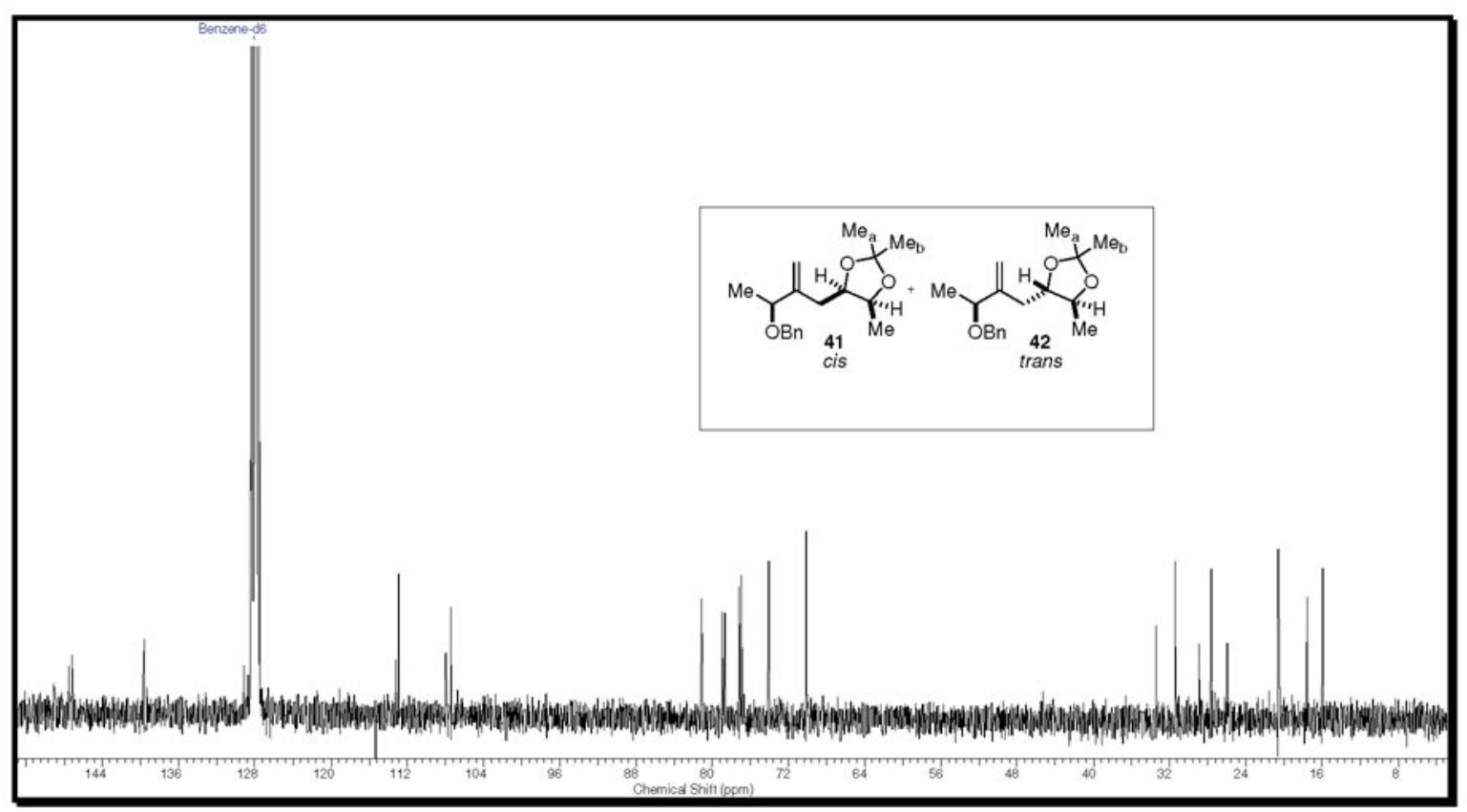

Figure 61S. ${ }^{13} \mathrm{C}$ NMR $\left(\mathrm{C}_{6} \mathrm{D}_{6}, 300 \mathrm{MHz}\right)-(4 R, 5 S)-4-((S)$-3-(benzyloxy)-2-methylenebutyl)-2,2,5-trimethyl-1,3-dioxolane (41) and (4S,5S)-4- $((S)-3$ (benzyloxy)-2-methylenebutyl)-2,2,5-trimethyl-1,3-dioxolane (42).

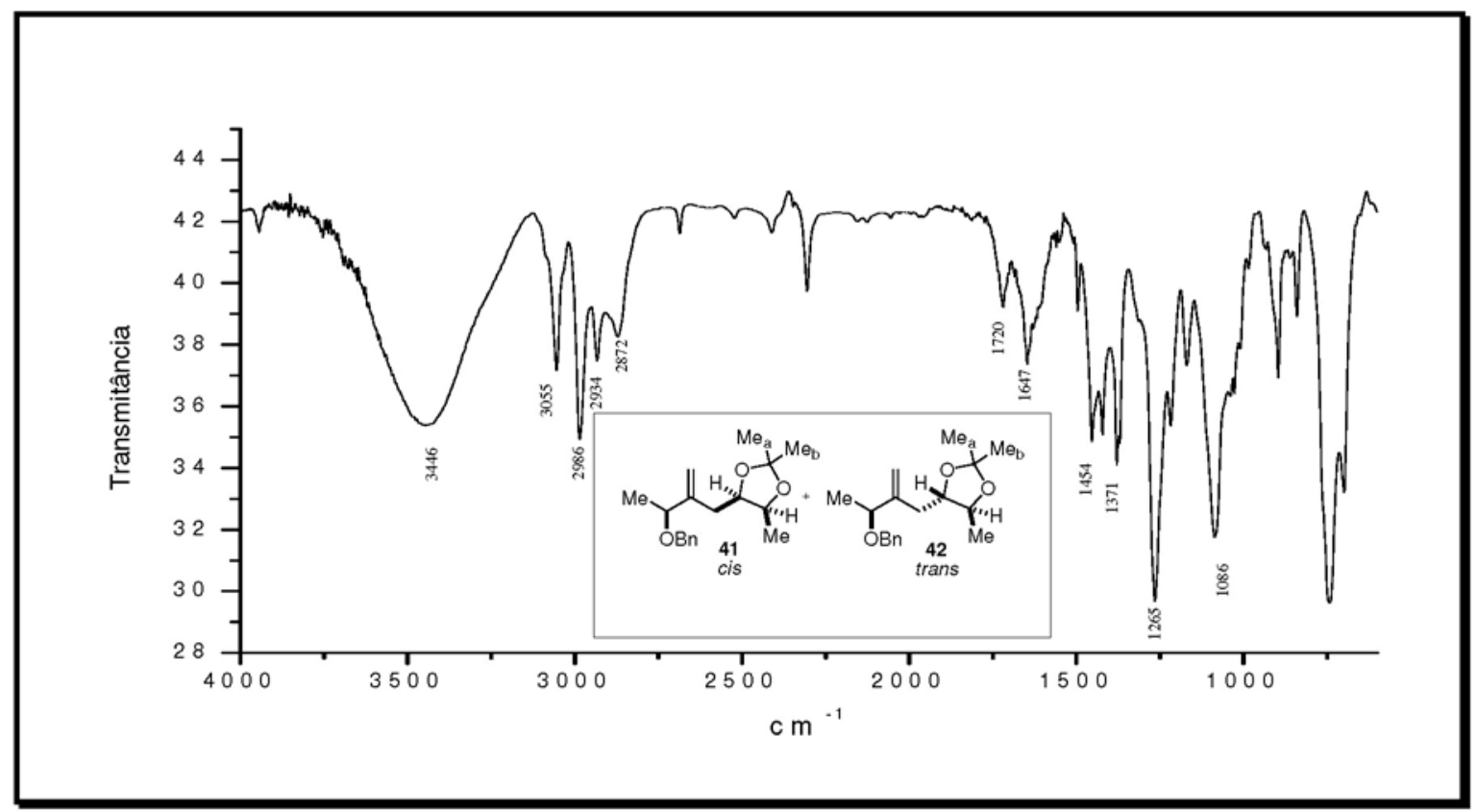

Figure 62S. IR (film) - (4R,5S)-4-((S)-3-(benzyloxy)-2-methylenebutyl)-2,2,5-trimethyl-1,3-dioxolane (41) and (4S,5S)-4-((S)-3-(benzyloxy)-2methylenebutyl)-2,2,5-trimethyl-1,3-dioxolane (42). 


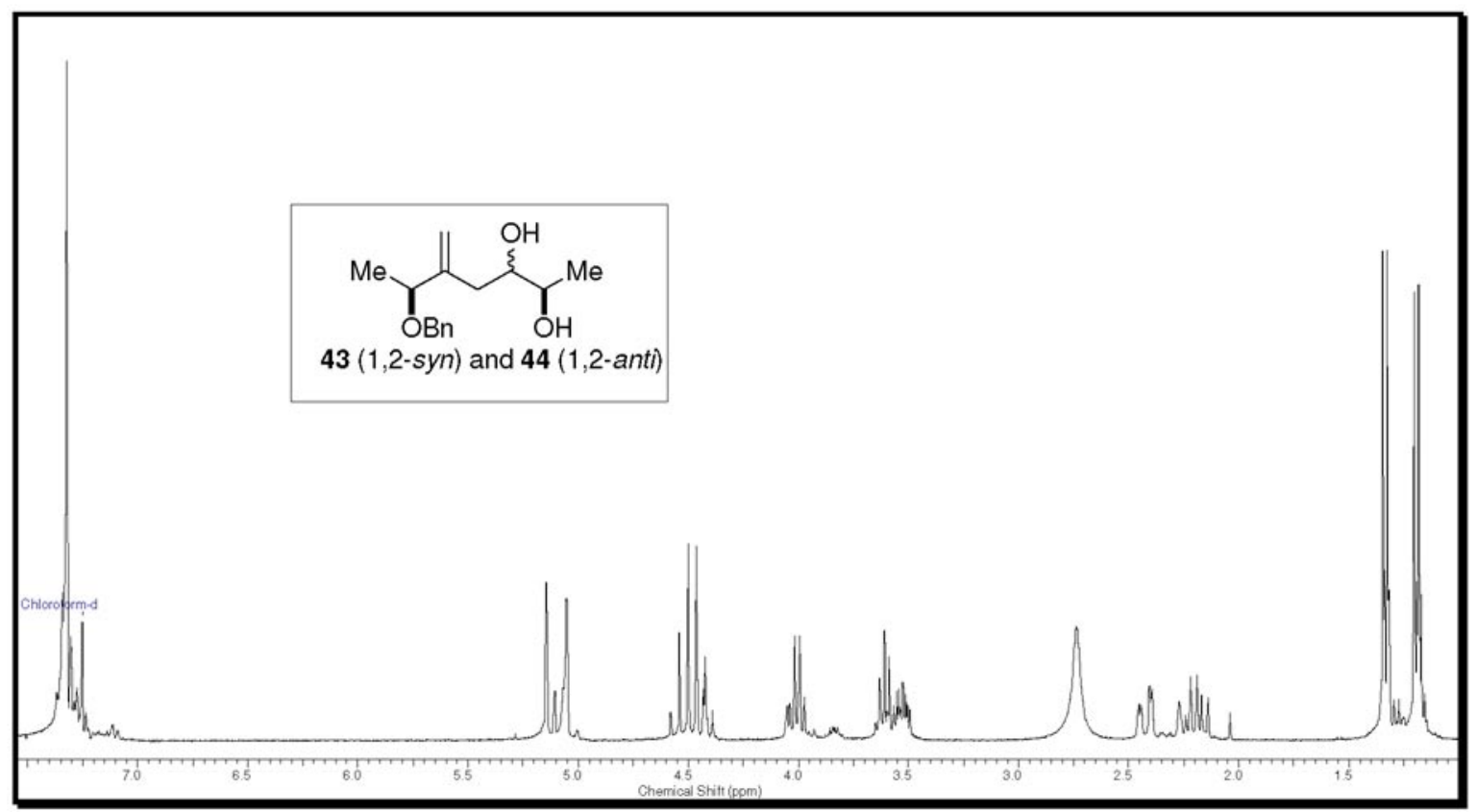

Figure 63S. ${ }^{1} \mathrm{H} \mathrm{NMR}\left(\mathrm{CDCl}_{3}, 300 \mathrm{MHz}\right)$ - (2R,6S)-6-(benzyloxy)-5-methyleneheptane-2,3-diol (43) and (44).

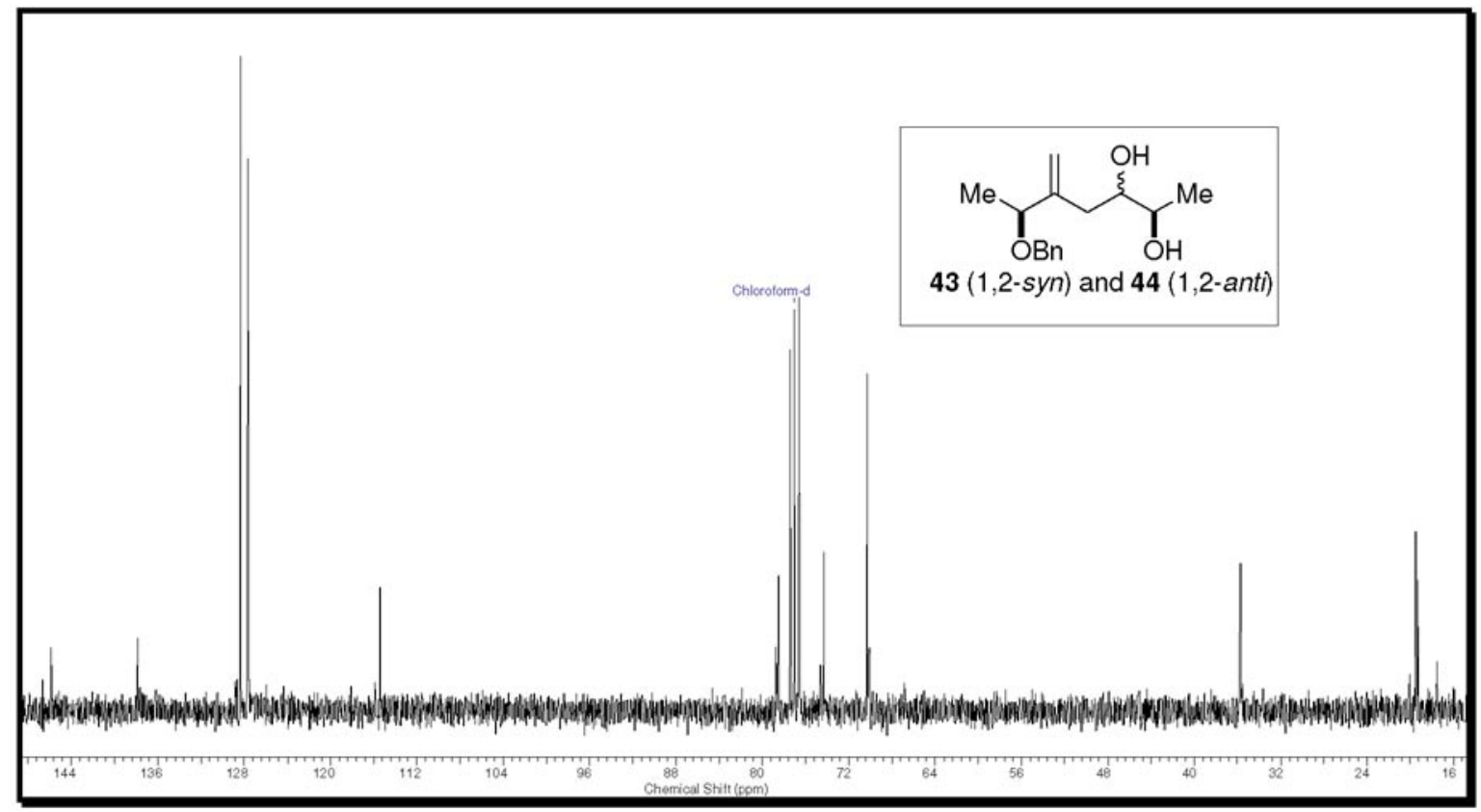

Figure 64S. ${ }^{13} \mathrm{C} \mathrm{NMR}\left(\mathrm{CDCl}_{3}, 75 \mathrm{MHz}\right)$ - (2R,6S)-6-(benzyloxy)-5-methyleneheptane-2,3-diol (43) and (44). 
Vol. 00, No. 00, 2009

Dias et al.

S39

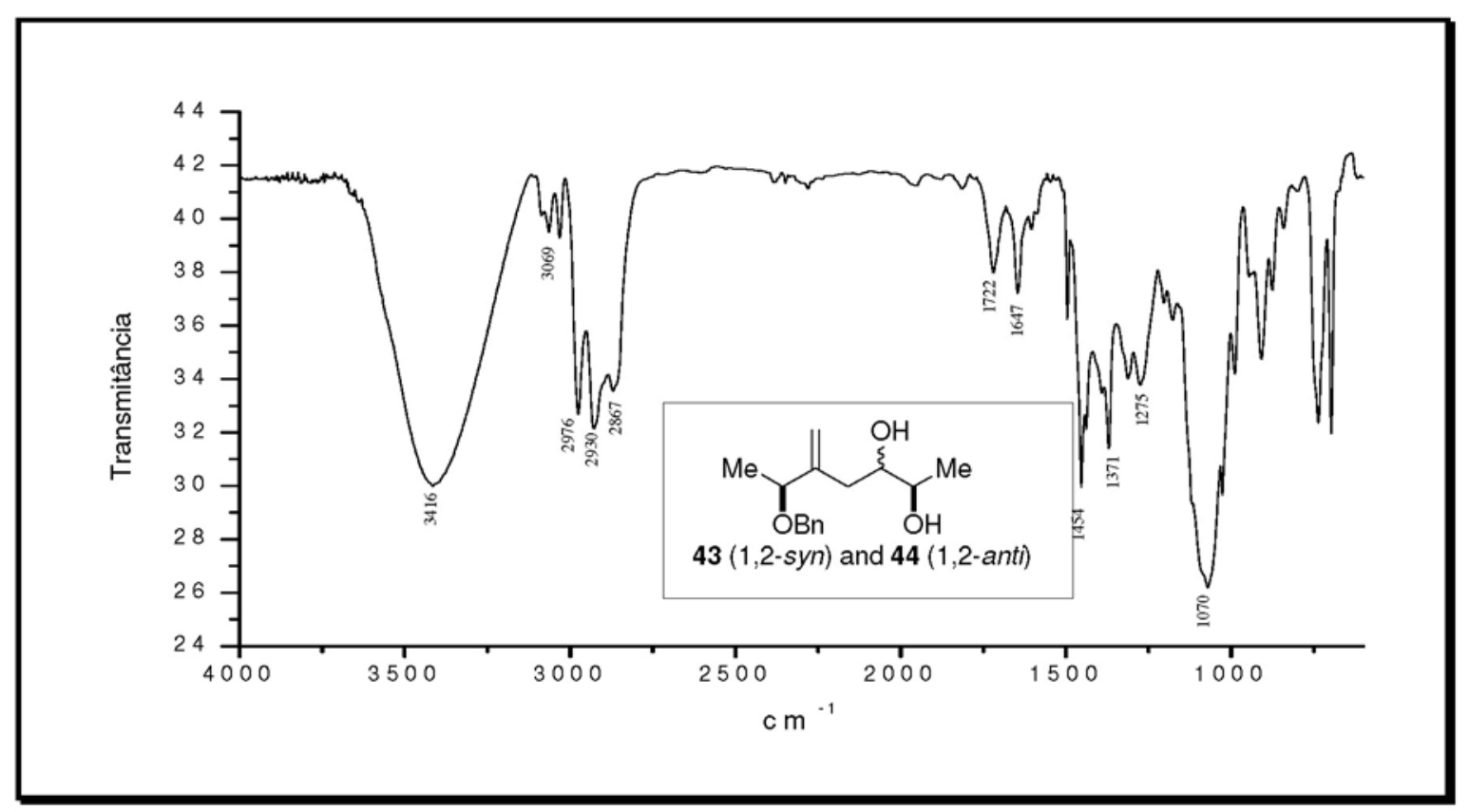

Figure 65S. IR (film) - (2R,6S)-6-(benzyloxy)-5-methyleneheptane-2,3-diol (43) and (44).

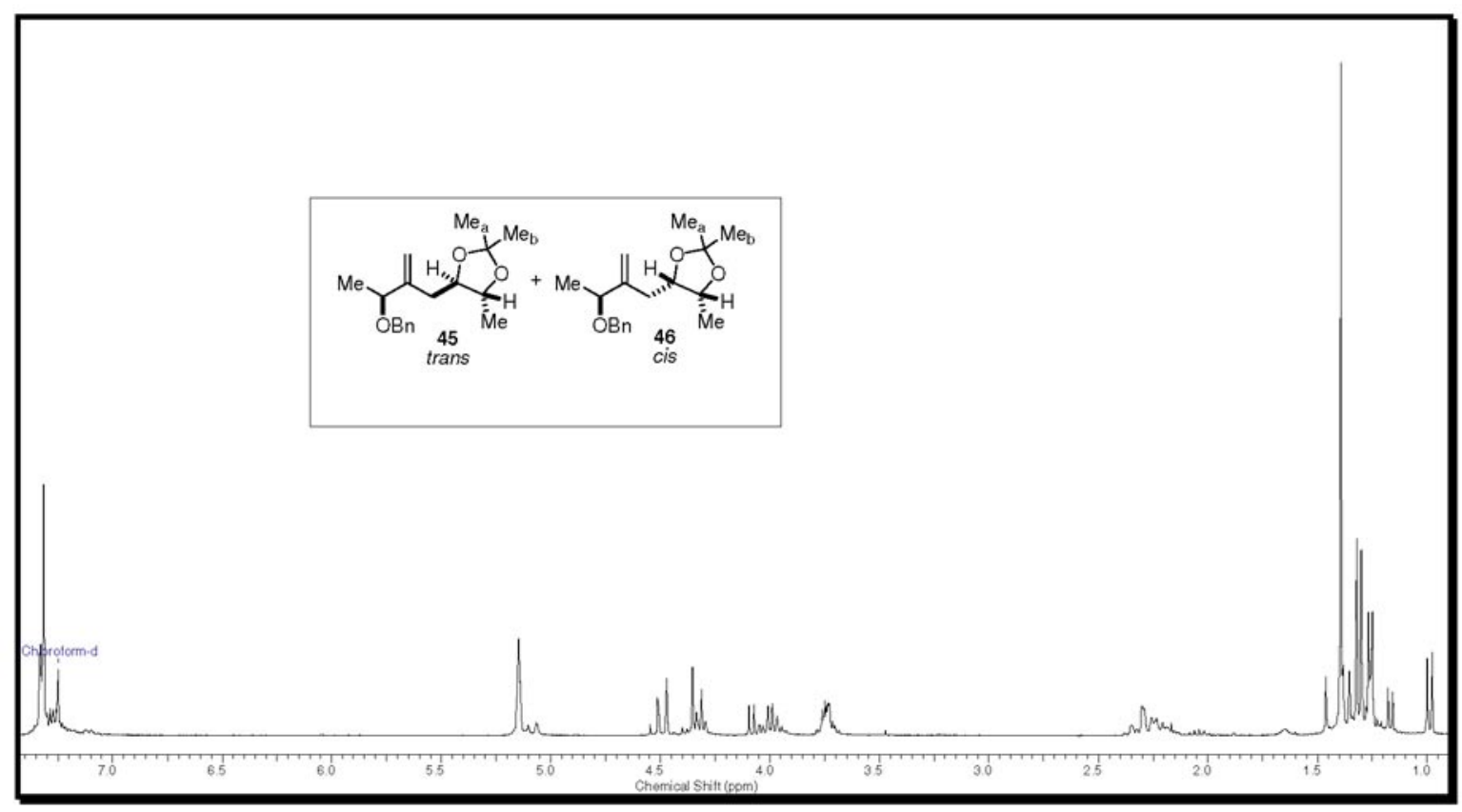

Figure 66S. ${ }^{1} \mathrm{H}$ NMR $\left(\mathrm{CDCl}_{3}, 250 \mathrm{MHz}\right)$ - (4R,5R)-4-((S)-3-(benzyloxy)-2-methylenebutyl)-2,2,5-trimethyl-1,3-dioxolane (45) and (4S,5R)-4-((S)-3(benzyloxy)-2-methylenebutyl)-2,2,5-trimethyl-1,3-dioxolane (46). 


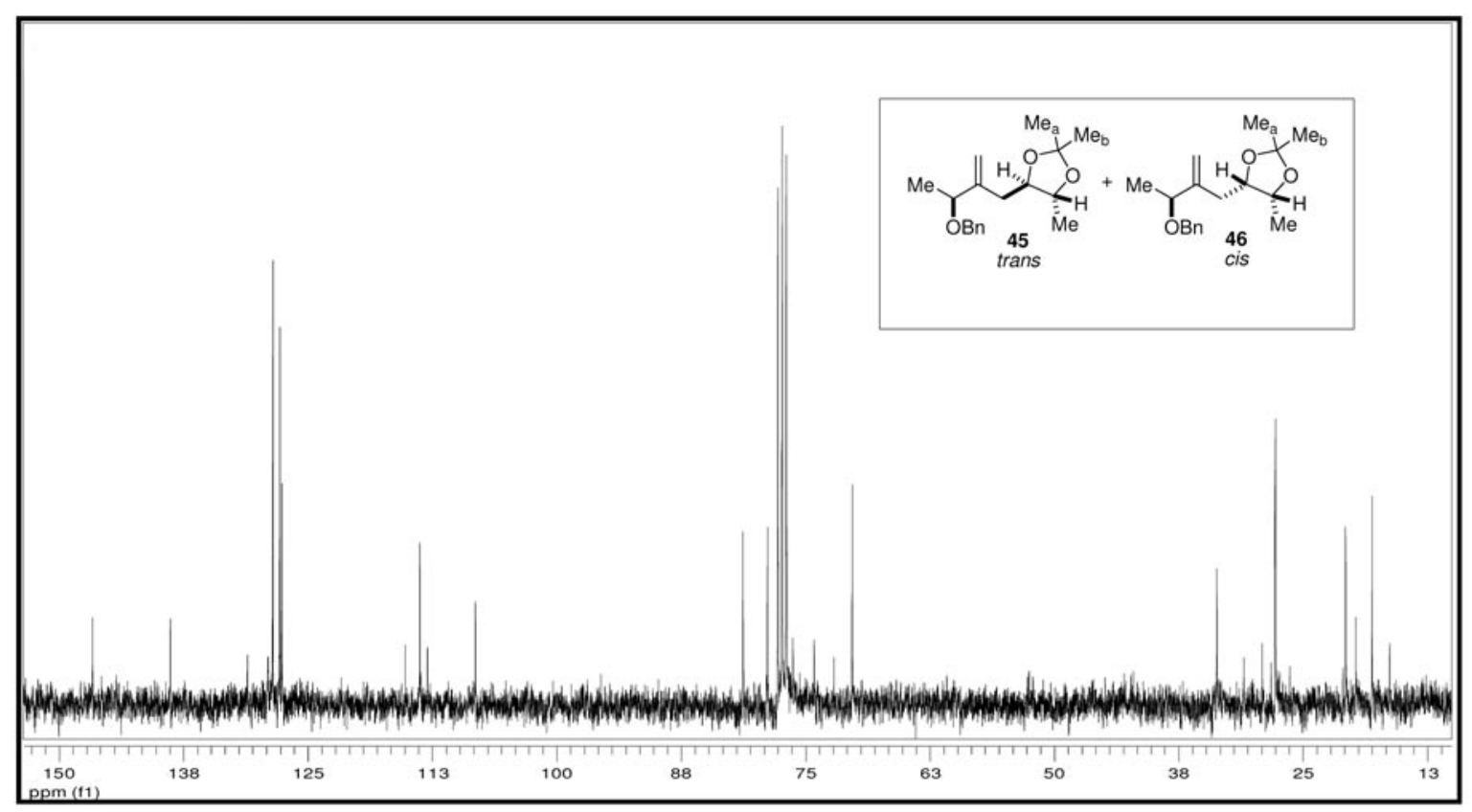

Figure 67S. ${ }^{13} \mathrm{C} \mathrm{NMR}\left(\mathrm{CDCl}_{3}, 63 \mathrm{MHz}\right)$ - (4R,5R)-4-((S)-3-(benzyloxy)-2-methylenebutyl)-2,2,5-trimethyl-1,3-dioxolane $(\mathbf{4 5})$ and $(4 S, 5 R)-4-((S)-3$ (benzyloxy)-2-methylenebutyl)-2,2,5-trimethyl-1,3-dioxolane (46).

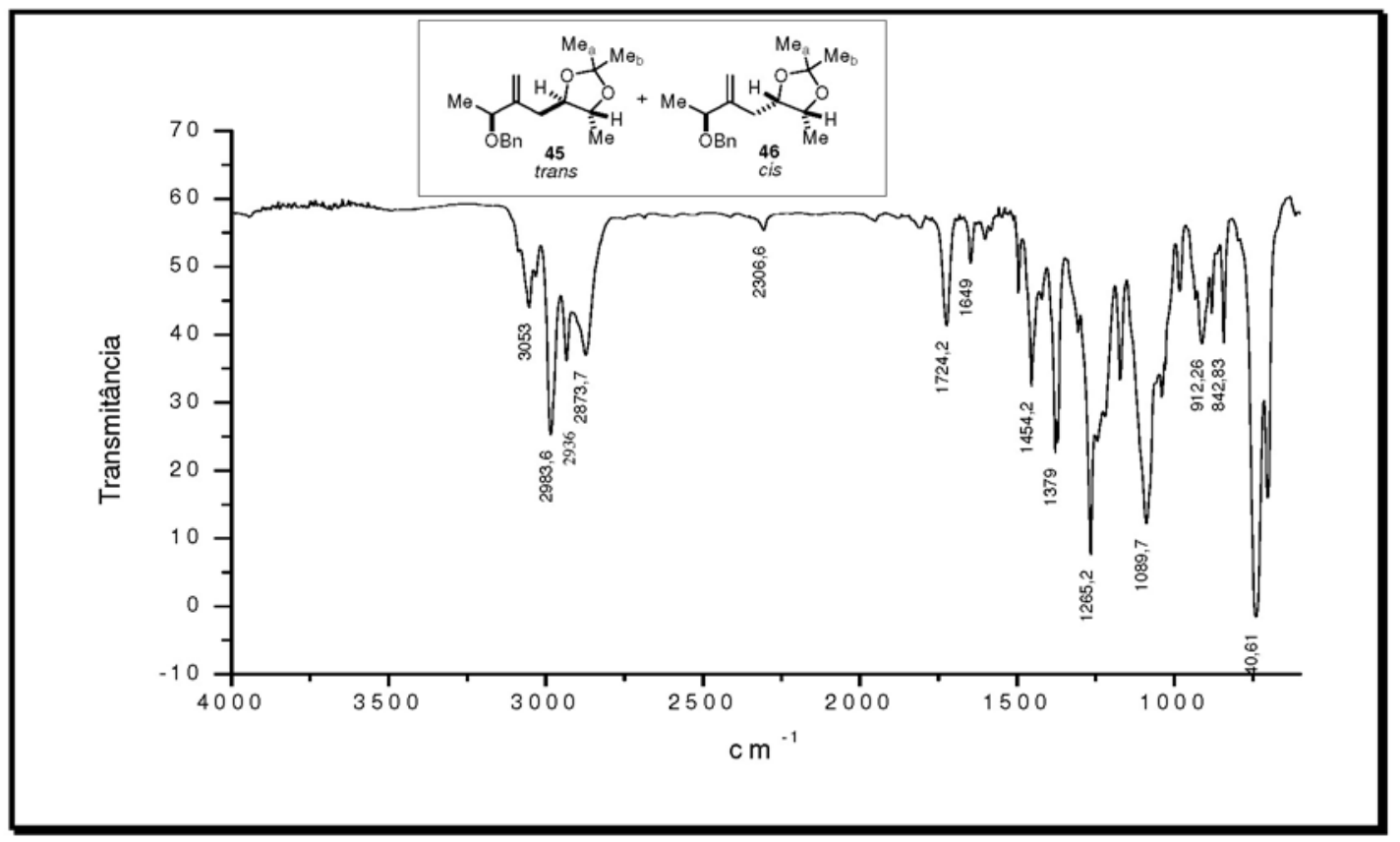

Figure 68S. IR (film) - (4R,5R)-4-((S)-3-(benzyloxy)-2-methylenebutyl)-2,2,5-trimethyl-1,3-dioxolane (45) and (4S,5R)-4-((S)-3-(benzyloxy)-2methylenebutyl)-2,2,5-trimethyl-1,3-dioxolane (46). 
Vol. 00, No. 00, 2009

Dias et al.

S41

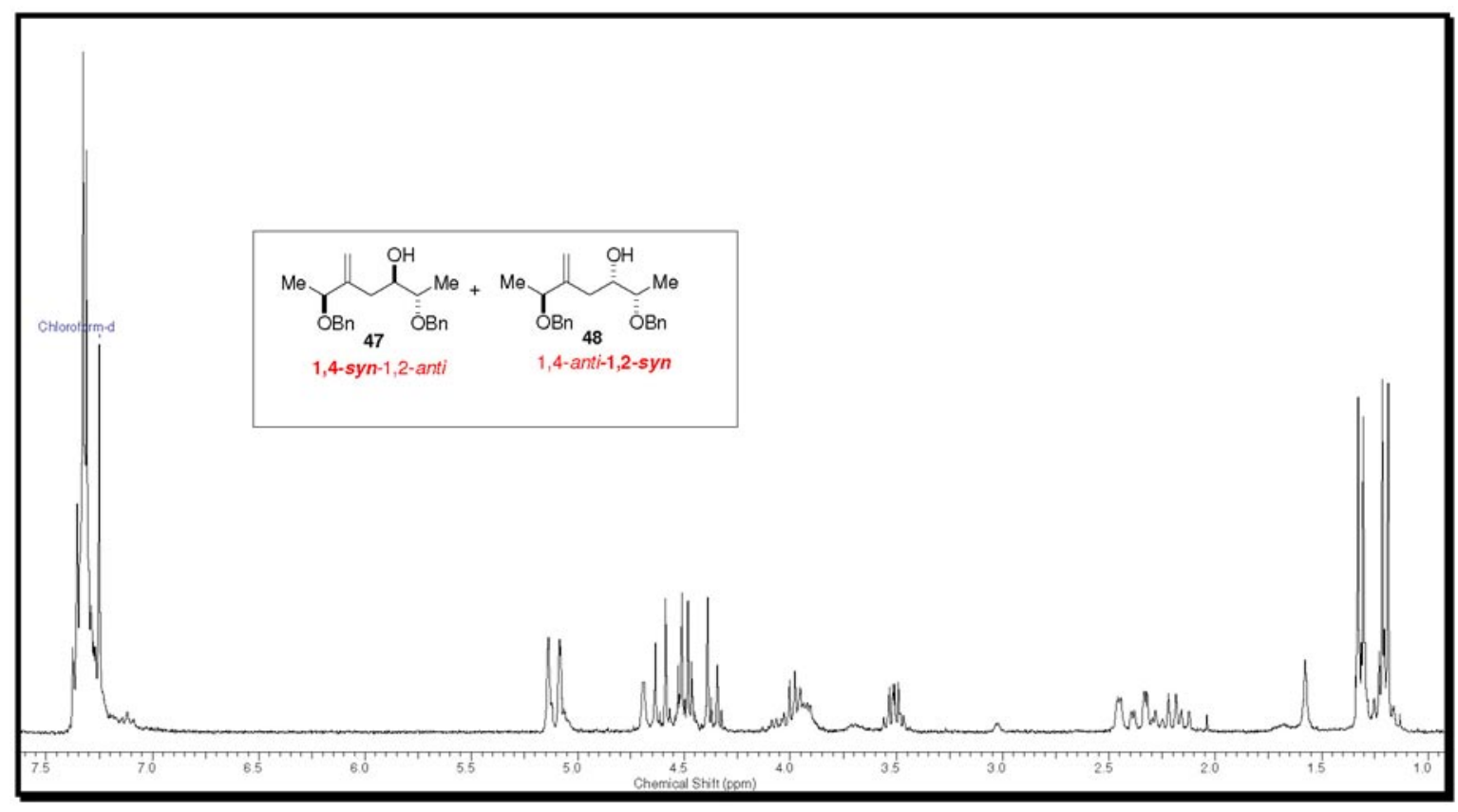

Figure 69S. ${ }^{1} \mathrm{H} \mathrm{NMR}\left(\mathrm{CDCl}_{3}, 250 \mathrm{MHz}\right)$ - (2S,3R,6S)-2,6-bis(benzyloxy)-5-methyleneheptan-3-ol (47) and (2S,3S,6S)-2,6-bis(benzyloxy)-5methyleneheptan-3-ol (48).

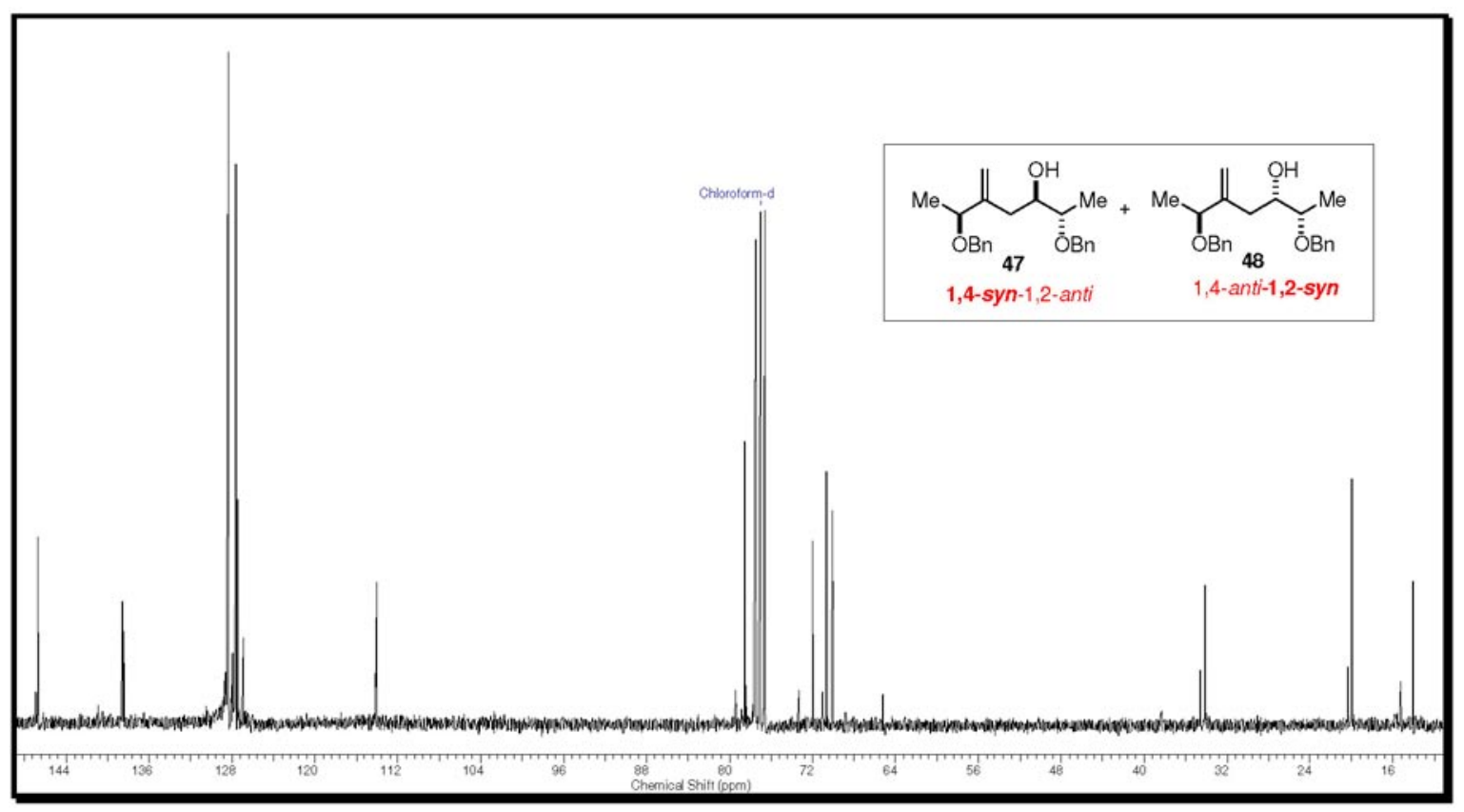

Figure 70S. ${ }^{13} \mathrm{C}$ NMR $\left(\mathrm{CDCl}_{3}, 63 \mathrm{MHz}\right)$ - (2S,3R,6S)-2,6-bis(benzyloxy)-5-methyleneheptan-3-ol (47) and (2S,3S,6S)-2,6-bis(benzyloxy)-5methyleneheptan-3-ol (48). 


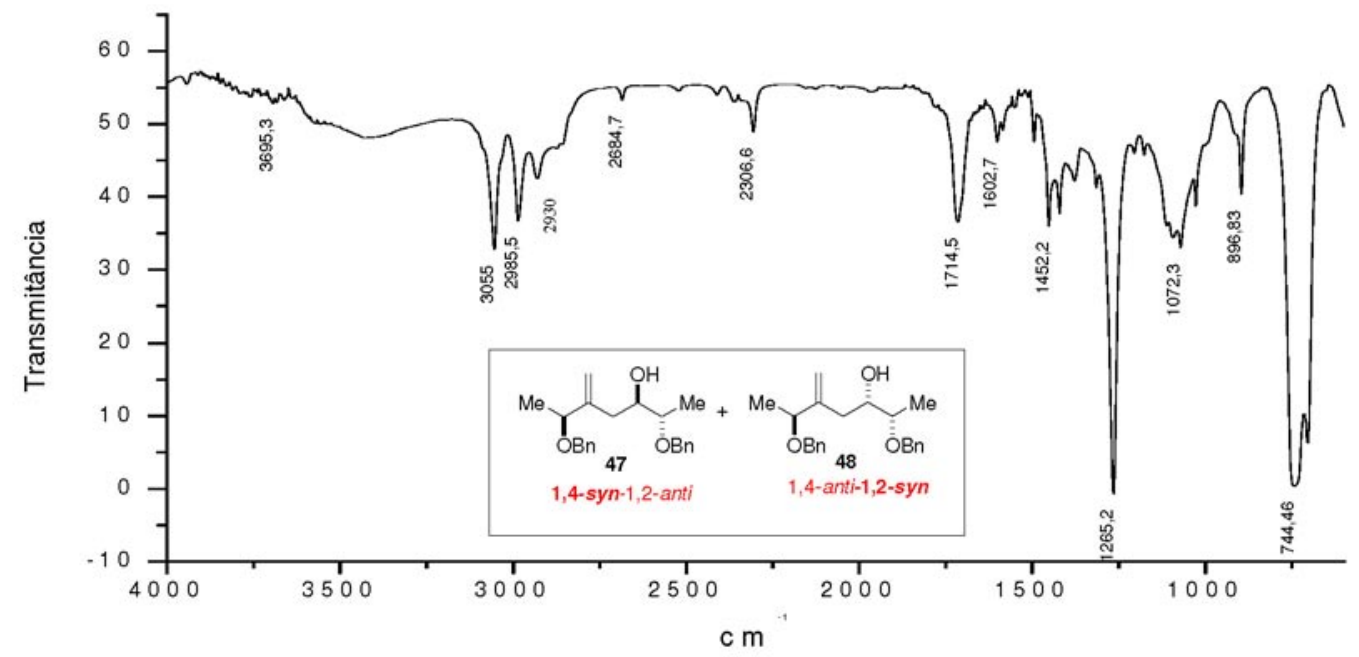

Figure 71S. IR (film) - (2S,3R,6S)-2,6-bis(benzyloxy)-5-methyleneheptan-3-ol (47) and (2S,3S,6S)-2,6-bis(benzyloxy)-5-methyleneheptan-3-ol (48).

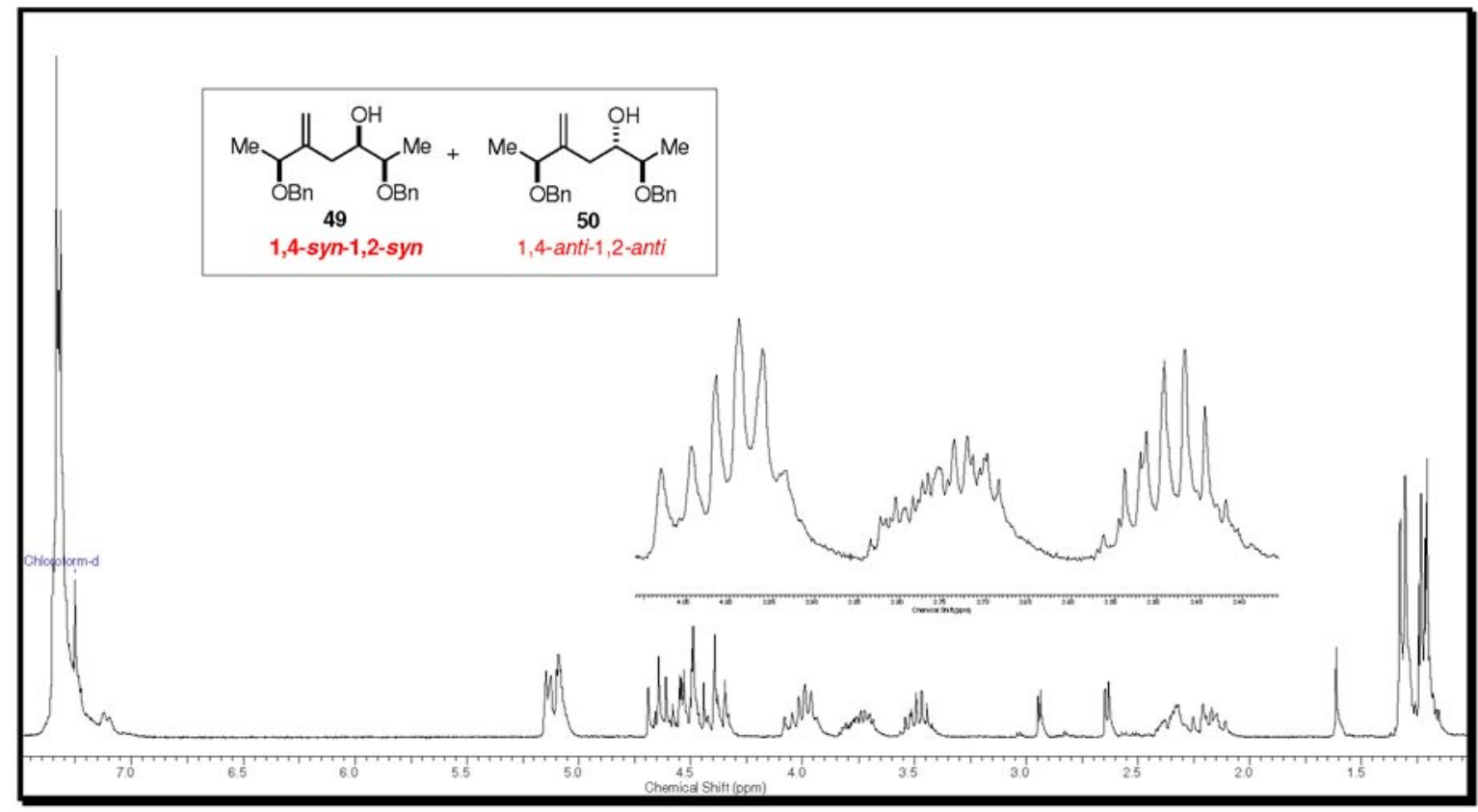

Figure 72S. ${ }^{1} \mathrm{H} \mathrm{NMR}\left(\mathrm{CDCl}_{3}, 250 \mathrm{MHz}\right)$ - (2R,3R,6S)-2,6-bis(benzyloxy)-5-methyleneheptan-3-ol (49) and (2R,3S,6S)-2,6-bis(benzyloxy)-5methyleneheptan-3-ol (50). 


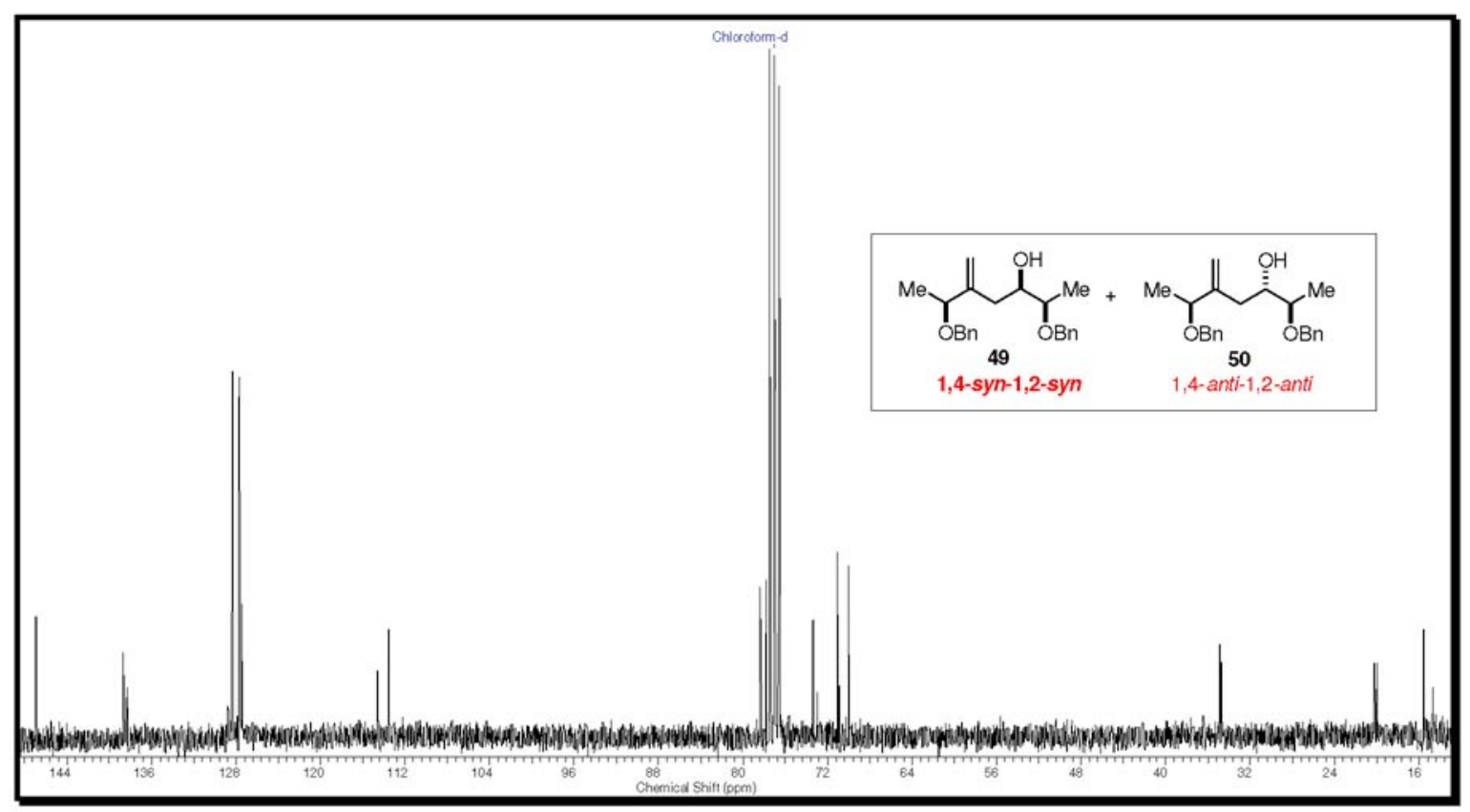

Figure 73S. ${ }^{13} \mathrm{C}$ NMR $\left(\mathrm{CDCl}_{3}, 63 \mathrm{MHz}\right)(2 R, 3 R, 6 S)$-2,6-bis(benzyloxy)-5-methyleneheptan-3-ol (49) and (2R,3S,6S)-2,6-bis(benzyloxy)-5methyleneheptan-3-ol (50).

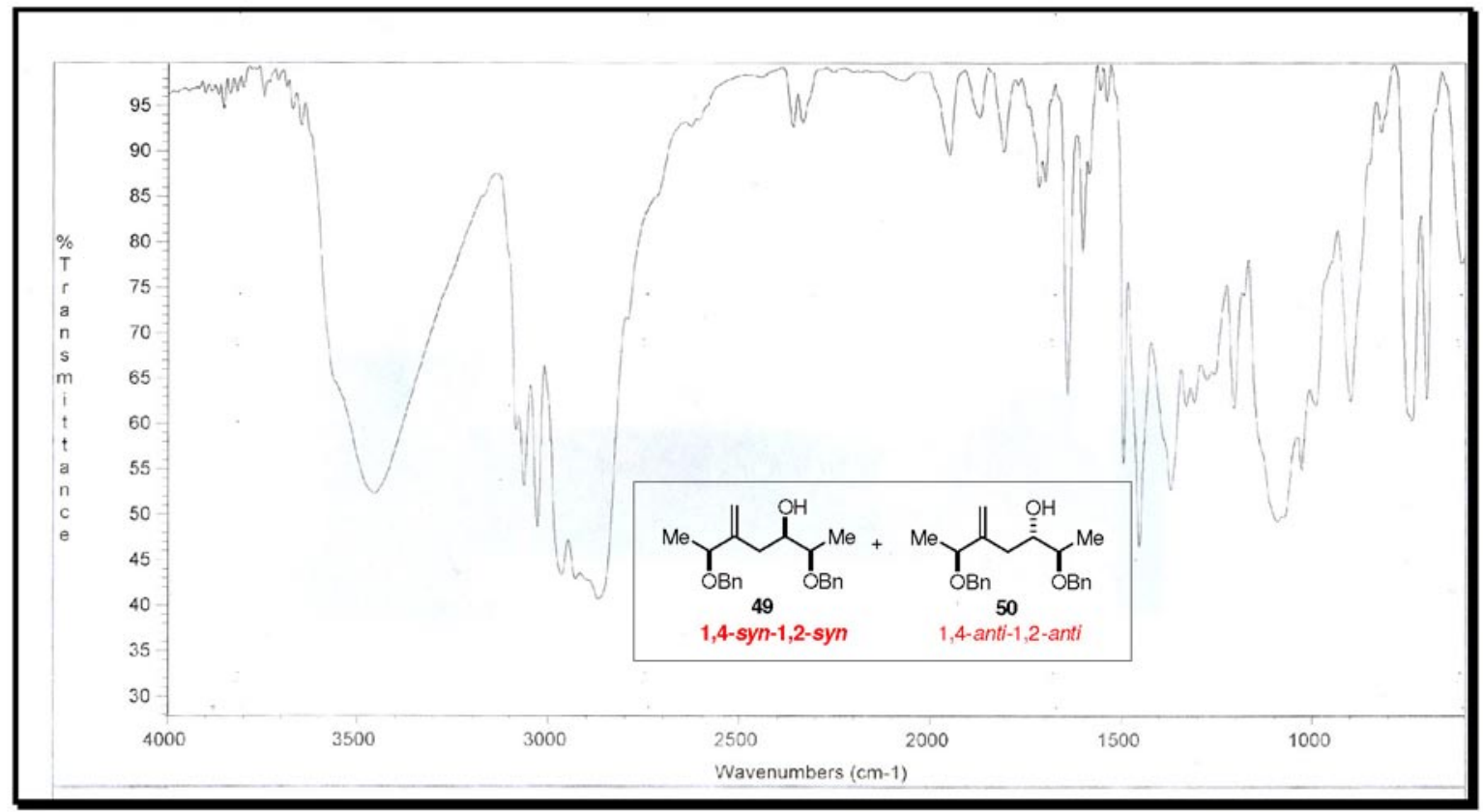

Figure 74S. IR (film) - (2R,3R,6S)-2,6-bis(benzyloxy)-5-methyleneheptan-3-ol (49) and (2R,3S,6S)-2,6-bis(benzyloxy)-5-methyleneheptan-3-ol (50). 